\title{
UNCONTROLLED STORAGE TEST OF THE MODULAR ARTILLERY CHARGE SYSTEM (MACS)
}

\author{
Chandrark Patel \\ William Zepp
}

January 2004

ARMAMENT RESEARCH, DEVELOPMENT AND
ENGINEERING CENTER
Quality Engineering \& System Assurance
Picatinny, New Jersey

Approved for public release; distribution is unlimited. 
The views, opinions, and/or findings contained in this report are those of the author(s) and should not be construed as an official Department of the Army position, policy, or decision, unless so designated by other documentation.

The citation in this report of the names of commercial firms or commercially available products or services does not constitute official endorsement by or approval of the U.S. Government.

Destroy this report when no longer needed by any method that will prevent disclosure of its contents or reconstruction of the document. Do not return to the originator. 


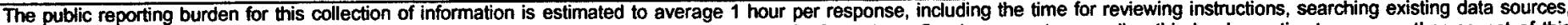

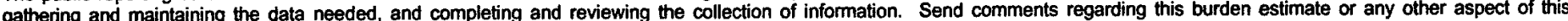

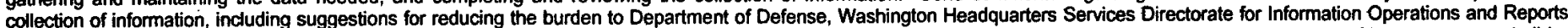

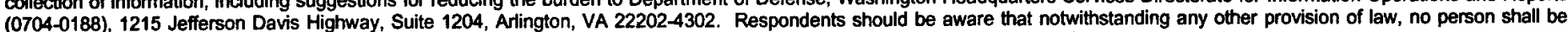
subject to any penalty for failing to comply with a collection of information if it does not display a currently valid OMB control number.

PLEASE DO NOT RETURN YOUR FORM TO THE ABOVE ADDRESS.

\begin{tabular}{c|c}
$\begin{array}{c}\text { 1. REPORT DATE (DD-MM-YYYY) } \\
\text { January } 2003\end{array}$ & 2. REPORT TYPE \\
\hline
\end{tabular}

4. TITLE AND SUBTITLE

UNCONTROLLED STORAGE TEST OF THE MODULAR ARTILLERY CHARGE SYSTEM (MACS)

4

6. AUTHORS

Chandrark Patel and William Zepp
3. DATES COVERED (From - To) 5b. GRANT NUMBER

5c. PROGRAM ELEMENT NUMBER

5d. PROJECT.NUMBER

5e. TASK NUMBER

5f. WORK UNIT NUMBER

8. PERFORMING ORGANIZATION REPORT NUMBER

ARDEC, QESA

Product Quality Management (AMSRD-AAR-QEM-A)

Picatinny, NJ 07806-5000

9. SPONSORING/MONITORING AGENCY NAME(S) AND ADDRESS(ES)

ARDEC, EM

Technical Research Center (AMSRD-AAR-EMK)

Picatinny, NJ 07806-5000

12. DISTRIBUTION/AVAILABILITY STATEMENT

Approved for public release; distribution is unlimited.

\section{SUPPLEMENTARY NOTES}

\section{ABSTRACT}

Uncontrolled storage test of the Modular Artillery Charges System (MACS) M232 charge was conducted at Yuma Proving Grounds in 2002. The test was conducted to determine effect of ambient temperature conditioning on muzzle velocity precision. Data from this test shows that a group of charges stored in the packaging containers in the Yuma desert environment during summer months did not exhibit degradation in muzzle velocity standard deviation when compared to charges conditioned to a uniform temperature in a conditioning box.

15. SUBJECT TERMS

MACS Temperature Precision Velocity

\begin{tabular}{|c|c|c|c|c|c|}
\hline 16. SECUR & CLASSIFICAT & N OF: & 17. LIMITATION OF & 18. NUMBER & 19a. NAME OF RESPONSIBE PERSON \\
\hline $\begin{array}{c}\text { a. REPORT } \\
U\end{array}$ & $\begin{array}{c}\text { b. ABSTRACT } \\
U\end{array}$ & $\begin{array}{c}\text { c. THIS PAGE } \\
U\end{array}$ & SAR & $\begin{array}{l}\text { PAGES } \\
75\end{array}$ & $\begin{array}{l}\text { 19b. TELEPHONE NUMBER (Include area } \\
\text { code) (973) 724-8507 }\end{array}$ \\
\hline
\end{tabular}




\section{CONTENTS}

\section{Page}

$\begin{array}{lr}\text { Background } & 1\end{array}$

$\begin{array}{ll}\text { Introduction } & 2\end{array}$

$\begin{array}{ll}\text { Discussion } & 3\end{array}$

Phase $1 \quad 3$

Phase $2 \quad 6$

$\begin{array}{ll}\text { Summary } & 8\end{array}$

$\begin{array}{lr}\text { Conclusions } & 8\end{array}$

Appendix - Test Data and Analysis 11

$\begin{array}{lr}\text { Distribution List } & 69\end{array}$ 


\section{BACKGROUND}

For years, the Artillery community has studied and identified powder temperature as an important parameter in determining the fire control solution for a mission.

Tabular firing tables as well as digital fire controls are designed to correct the expected projectile trajectory for the difference in powder temperature from the normal, defined as ambient or $21^{\circ} \mathrm{C}$. The powder temperature is recorded periodically (usually morning and afternoon) by inserting a $M 1$ powder thermometer into one charge assumed representative of the combat load. The recorded temperature would, in essence, adjust the group's center-ofimpact based on the assumption that all charges were approximately the same temperature.

Until recently, this was an acceptable procedure, especially when one considers the technology that was previously available before digital fire control evolved. Without a computerized fire control system for each weapon, the burden to correct every round for powder temperature would be unmanageable. However, with the leap-ahead weapon systems, such as, Crusader and, subsequently, NLOS-C, the necessary technology needed to correct every firing for individual temperature could be integrated into every platform, albeit, at a cost. With these advanced weapons delivering high volumes of fire support at high rates and multiple targeting, there is significant savings in the logistic area if better precision can be achieved, thus potentially offsetting the cost of the temperature management system.

Studies by other agencies, based on historical temperature sensitivity with bag charges, showed one of the drivers to achieving improved precision is management of the propellant temperature. Contrary to that analysis was a study done by the Modular Artillery Charge System (MACS) team on conditioning temperature. The concern of the study was to determine the minimum conditioning time required to bring the MACS to equilibrium during temperature conditioning. The MACS is the next generation propelling charge, contained in a combustible case to achieve rigidity for auto handling in the new artillery weapon systems. The combustible case is an excellent thermal insulator. A study performed at Yuma Proving Grounds with thermocoupled XM230 charges (the predecessor to the M232 charge) in September 1997 showed that a minimum conditioning time of at least 16 to $20 \mathrm{hrs}$ was required to achieve a constant temperature throughout the charge (fig. 1). During this test, on Day 1 charges were conditioned from their $70^{\circ} \mathrm{F}$ ambient temperature to $-60^{\circ} \mathrm{F}$, on Day 2 the charges were brought back to $70^{\circ} \mathrm{F}$ from $-60^{\circ} \mathrm{F}$. On Day 3 , the charges were conditioned from $70^{\circ} \mathrm{F}$ to $145^{\circ} \mathrm{F}$ and finally on Day 4 , the charges were conditioned from $145^{\circ} \mathrm{F}$ to $-60^{\circ} \mathrm{F}$. 


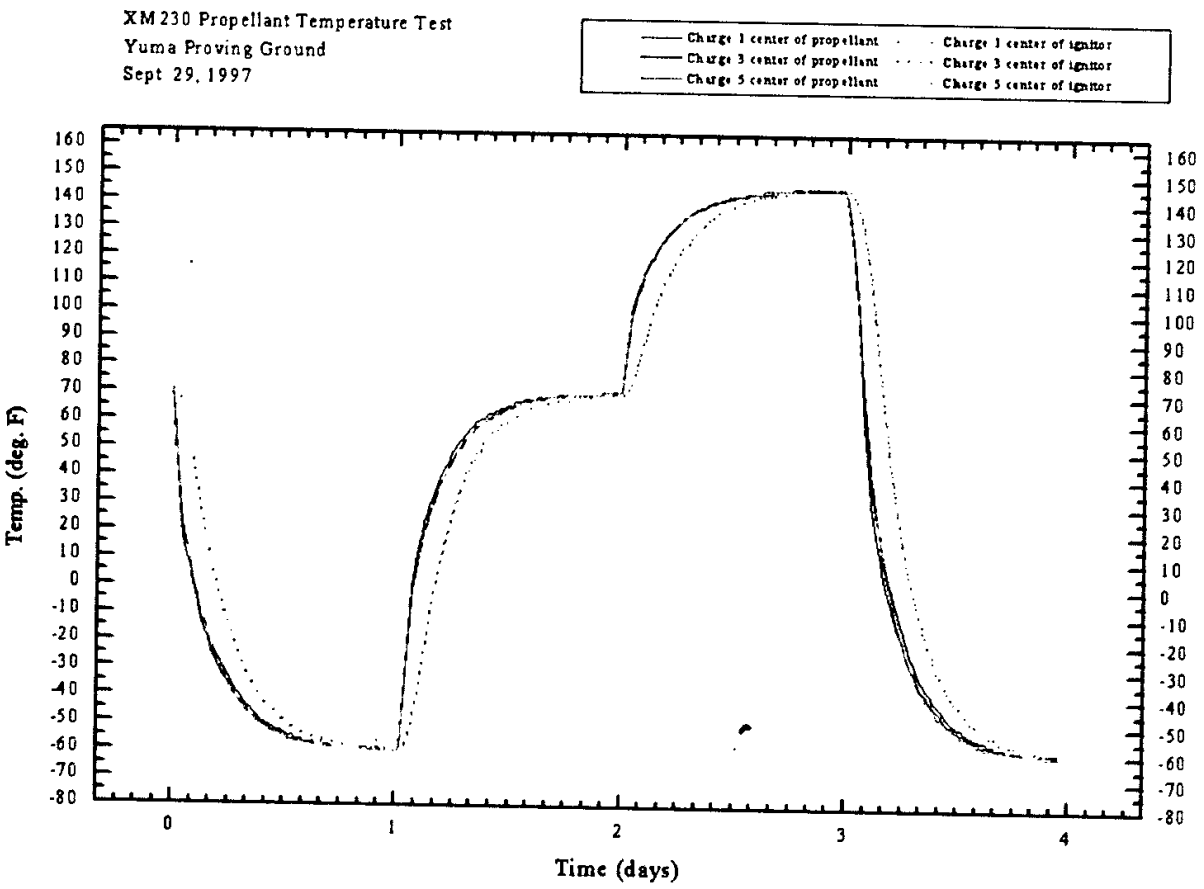

Figure 1

XM230 propellant temperature test at Yuma Proving Grounds (September 1997)

Responding to the studies indicating a need for thermal management of the propellant, a Radio Frequency Transponder (RF Tag) program was conducted. The RF Tag had the capability of measuring temperature within the MACS; however, the placement of the tag location was in question. An extensive firing test (partial-soak test) was conducted with thermocoupled charges conditioned along side the test charges in August 1998. Since the thermocoupled charges were not to be fired, there was a thermocouple placed in nearly every conceivable location, given the symmetry of the charge. The best correlation achieved between velocity and measured temperature was at the center of the ignition powder, located at the geometrical center of the charge. Reference Partial-Soak Test data conducted in August 1998.

The MACS team, however, was skeptical to the value added of any temperature management system for individual charge temperatures, given the results of the temperature conditioning study and the RF Tag program. Given the long time to achieve thermal saturation and the critical charge location being the last area to react to a temperature change, an additional study was justifiable to further evaluate the value of managing individual temperature. The study is
the basis of this report.

\section{INTRODUCTION}

As stated in the Background, the objective of the test program of this report was to evaluate the degradation of muzzle velocity consistency brought on by the non-uniform temperature distribution. The most severe condition conceivable was a freestanding pallet of M232 propelling charges subjected to desert conditions with it's corresponding temperature swings from day to night and the severe solar loading. During this test, the palletized M232 charges 
were exposed to temperatures up to $45^{\circ} \mathrm{C}$ and temperature ranges of up to $20^{\circ} \mathrm{C}$. The $\mathrm{M} 231$ propelling charge was not subjected to similar testing because its sensitivity to temperature is considerably less than that of the M232 propelling charge.

No conditioning by the howitzer's magazine structure occurred during these tests due to the limited exposure of the propelling charge to the magazine temperature, 10 min maximum. Therefore, no evaluation or conclusions can be made regarding increment temperature distributions as a result of extended storage in a self-propelled howitzer (SPH) propellant storage magazine.

The test was actually conducted in two phases. The first phase, phase 1 , compared the ballistic performance of charges conditioned by the local ambient environment at Yuma Proving Ground to charges of the same lot conditioned in a controlled conditioning box held at $21^{\circ} \mathrm{C}$. The data generated from this test was evaluated by comparing each test group to the control group that was fired adjacent to the test group. Based on the results of phase I, showing the need for a temperature management system for individual charge temperature was unnecessary for this situation where the charges are loaded directly from pallets into the weapon and fired. Further testing was desirable to increase the confidence level for any subsequent decision. The control rounds were eliminated during subsequent testing (phase 2) to save costs and, therefore, only test groups were evaluated. A test group consisted of palletized charges exposed to desert conditions (without the use of a tarp as described in current field manuals to establish an extreme condition).

\section{DISCUSSION}

\section{Phase 1}

The first thought of the test program was to simply compare charges subjected to uncontrolled temperature conditioning with charges temperature conditioned. The worst case conceived was to subject a pallet of charges to desert conditions, expecting the largest solar loading possible. It was decided to perform the test at Yuma Proving Grounds leaving the test sample in the desert unprotected from solar loading and to condition a sample from the same lot to a constant $21^{\circ} \mathrm{C}$ for a minimum of $24 \mathrm{hrs}$. The test charge increment temperature was derived from the recorded temperature of the increment thermal emulators (ITEs). The ITEs are inert simulators of the MACS charges that maintain the true thermal conductivity of the live charges, but are inert and instrumented to record the temperature as a function of time. They are a product of a MACS contract with West Point. Next to the test sample pallet, a shadow pallet was placed containing the ITEs. The test assumed equality of temperature for increments in identical location within the pallet of both the "shadow" and "test" groups. The ITEs were distributed throughout the shadow pallet with live charges making up the difference.

For each charge, the individual increment temperatures were averaged to obtain a "charge" temperature based on a prior study by the Army Research Laboratory that showed under conditions where the temperature variation was less than $20^{\circ} \mathrm{F}$, averaging the temperatures of the individual increments correlated very well with their performance level. Thus, that approach was adapted for this study. 
Table 1 is a summary of the standard deviation and range of the temperatures for test groups, and the standard deviation in muzzle velocity for both test and control groups (control groups are assumed to have no variation in temperature based on temperature conditioning at constant temperature for over $24 \mathrm{hrs}$ ). The first number of the ID column represents the zone the charge was fired and second number indicates the occasion of firing; e.g., 3-1 is the first occasion at zone 3. For occasion 6-3, only one temperature data point was collected, therefore, range and standard deviation information is unavailable.

Table 1

Summary of temperature and muzzle velocity variation

\begin{tabular}{|c|c|c|c|c|}
\hline ID & T sd(C) & T range $\odot$ & TMV SD & CMV SD \\
\hline 3-1 & 1.0 & 2.4 & 1.7 & 1.2 \\
\hline $3-2$ & 0.5 & 1.0 & 1.2 & 2.6 \\
\hline $3-3$ & 0.7 & 1.3 & 1.2 & 2.0 \\
\hline & & & & \\
\hline 4-1 & 2.7 & 5.9 & 1.1 & 1.1 \\
\hline $4-2$ & 0.2 & 0.6 & 1.1 & 1.5 \\
\hline $4-3$ & 2.7 & 6.1 & 2.5 & 1.0 \\
\hline $5-1$ & 0.7 & 1.3 & 1.8 & 1.5 \\
\hline $5-2$ & 0.9 & 1.7 & 1.8 & 2.5 \\
\hline $5-3$ & 1.2 & 3.4 & 1.4 & 0.8 \\
\hline $5-4$ & 1.4 & 3.0 & 1.3 & 2.4 \\
\hline 55 & 1.9 & 4.6 & 1.8 & 0.4 \\
\hline $6-1$ & 2.5 & 5.6 & 1.9 & 1.6 \\
\hline $6-2$ & 2.3 & 5.0 & 1.6 & 1.1 \\
\hline $6-3$ & & & 0.9 & 2.3 \\
\hline $6-4$ & 0.7 & 2.1 & 1.3 & 1.0 \\
\hline $6-5$ & 2.7 & 5.8 & 1.7 & 1.3 \\
\hline
\end{tabular}

Figure 2 shows the temperature delta between the highest and lowest measured charge for each group. 


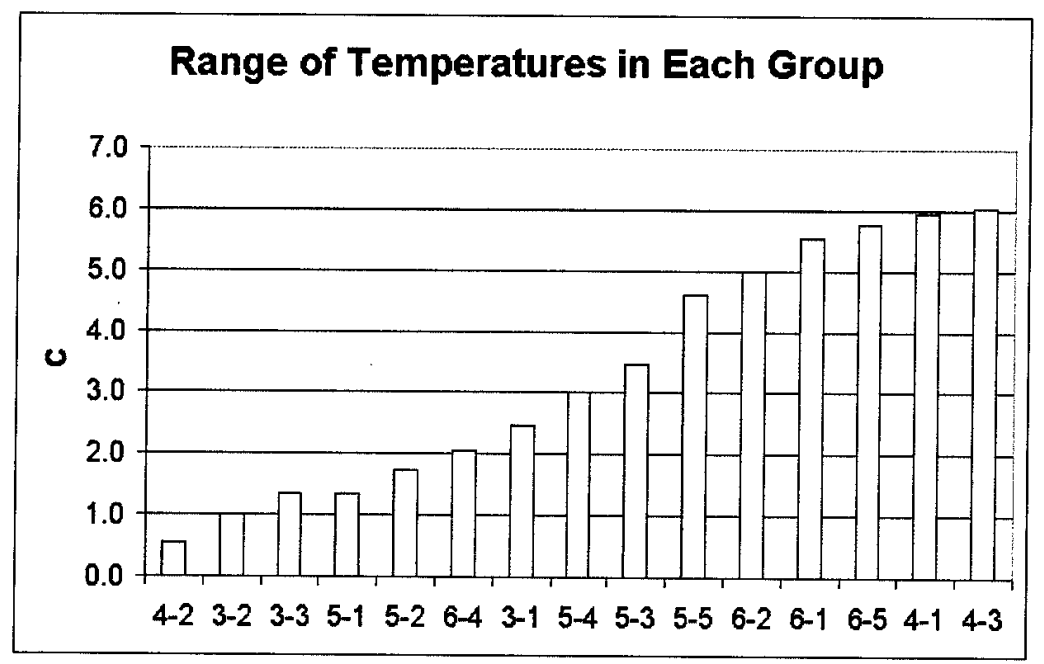

Figure 2

Range of temperatures in each group

A comparison of the muzzle velocity standard deviation for the test and control groups for zones 3 to 6 is presented in figure 3 . The velocity standard deviation of the test groups did not exhibit degradation when compared to the control groups, even though there was a measurable difference in temperature between propelling charges. Under the scenario tested, all test groups exhibited a distribution of charge increment temperatures less than $3^{\circ} \mathrm{C}$, a level once considered a requirement for Crusader. It is assumed the same would hold for NLOS-C, unless there are significant requirement changes in the future for transfer and firing rates.
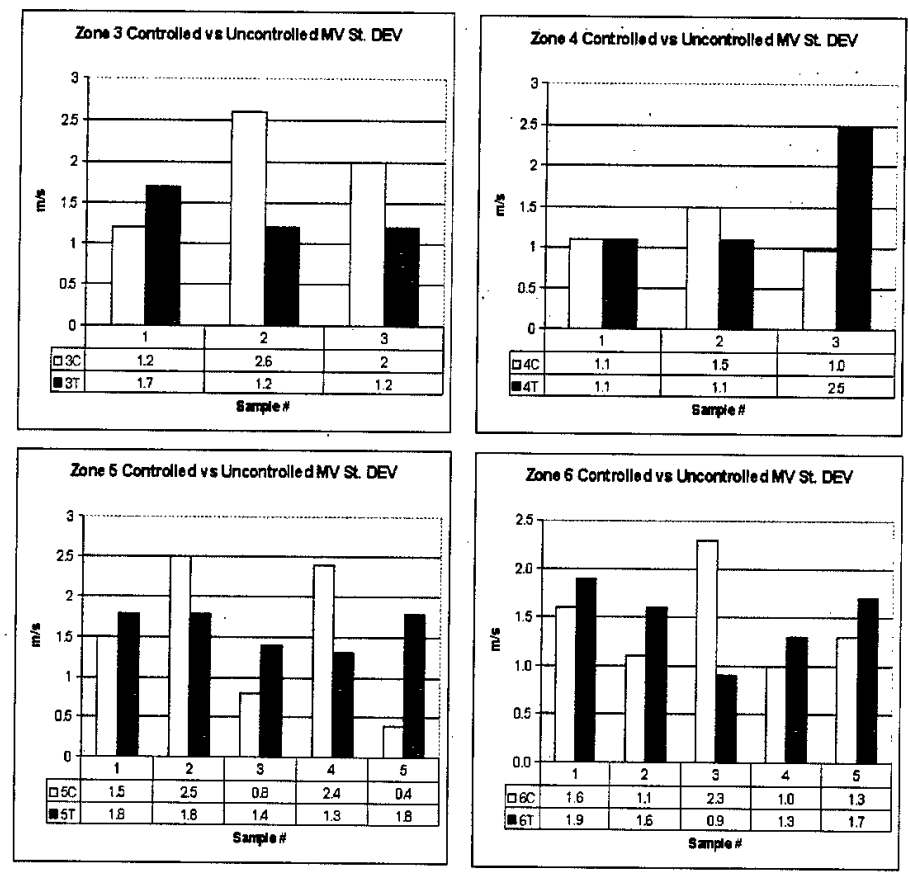

Figure 3

Muzzle velocity standard deviation comparison for zones 3 to 6 
As can be seen from the results of the testing, the test group variability was no worse than the control groups, in fact, on several occasions ( 6 out of 16 ), the uncontrolled temperature samples did better than the samples subjected to controlled storage conditions. It was decided that a second phase ( $p$ Phase 2) be performed to confirm the results and conclusions drawn on the first test. To reduce costs, the conditioning boxes being a cost driver, the control groups were eliminated. This allowed for substantially more testing of uncontrolled temperature samples. Additionally, the testing in phase 2 was further limited to zone 6 to maximize the database at the highest velocity level where the maximum effect of temperature variability is expected.

\section{Phase 2}

Phase 2 of the testing to evaluate temperature variability effects on muzzle velocity uniformity (precision) was conducted during 14 August to 25 September 2002 from SPH1 at Yuma Proving Ground. The charges were again conditioned in the Yuma desert environment in the packaging containers on a pallet. Charges were chosen for each group across the pallet to obtain a cross section of temperature ranges as expected to be the worst case in real life if the charges are uploaded in to a SPH. The internal temperature was obtained for a sample of these charges to determine the average temperature for each group. For this phase, a group consisted of 15 zone 6 rounds or $90 \mathrm{M} 232$ propelling charges uploaded at one time into the SPH1. Every effort was made to test each group as one set, but faults generated in the SPH1 sometimes caused a break in cadence of sufficient duration to split the group into two. Such occasions are noted in the table by sample sizes smaller than 15 for the group. Table 2 is a summary of the group's average temperature, temperature range between coolest and hottest charge measured, and the ambient air temperature when the data was obtained. The DayZone-Occ column represents which day of the test, zone, and the occasion number for that day; e.g., 1-6-1 is the first day, zone 6, occasion 1.

Table 2

Phase 2 results

\begin{tabular}{|c|c|c|c|c|c|}
\hline Day-zone-occ & $\mathrm{N}$ & Ambient & Chg T avg() & Chg T range $\odot$ & MV std dev \\
\hline $1-6-1$ & 15 & 38 & 32 & 2.8 & 1.4 \\
\hline $1-6-2$ & 15 & 42 & 34 & 1.8 & 0.9 \\
\hline $1-6-3$ & 15 & 44 & 40 & 3.1 & 2.9 \\
\hline $1-6-4$ & 15 & 44 & 42 & 5.5 & 1.5 \\
\hline $2-6-1$ & 15 & 34 & 30 & 12 & \\
\hline $2-6-2$ & 15 & $\frac{34}{36}$ & 30 & $\frac{7.3}{1.2}$ & $\frac{1.7}{1.5}$ \\
\hline $2-6-3$ & 15 & 38 & 32 & 2.7 & $\begin{array}{l}1.5 \\
3.0\end{array}$ \\
\hline $2-6-4$ & 15 & 38 & 34 & 4.9 & 1.3 \\
\hline & & & & & \\
\hline $3-6-1$ & 15 & 32 & 28 & 1.2 & 1.9 \\
\hline $3-6-2$ & 15 & 35 & 30 & 1.8 & 1.3 \\
\hline $3-6-3$ & 15 & 36 & 30 & 3.2 & 1.4 \\
\hline $3-6-4$ & 15 & 38 & 32 & 4.2 & 1.6 \\
\hline $4-6-1 A$ & 5 & 37 & 2 & 21 & 15 \\
\hline $4-6-18$ & 9 & 41 & 28 & $\frac{2.1}{3.6}$ & $\frac{7.5}{1.1}$ \\
\hline $4-6-2$ & 15 & 43 & 34 & 2.9 & 2.0 \\
\hline $4-6-3 A$ & 8 & 43 & 37 & 4.1 & 1.4 \\
\hline $4-6-3 B$ & 7 & 42 & 35 & 2.4 & 1.8 \\
\hline
\end{tabular}


Table 2

(continued)

\begin{tabular}{|c|c|c|c|c|c|}
\hline Day-zone-occ & $\mathbf{N}$ & Ambient & Chg T avg(C) & Chg $T$ range $\odot$ & MV std dev \\
\hline $5-6-1$ & 15 & 41 & 32 & 2.2 & 1.1 \\
\hline $5-6-2$ & 15 & 42 & 33 & 2.7 & 1.2 \\
\hline $5-6-3$ & 15 & 43 & 37 & 5.5 & 1.7 \\
\hline $5-6-4$ & 15 & 44 & 40 & 7.1 & 1.5 \\
\hline & & & & & \\
\hline $6-6-1$ & 8 & 40 & 34 & 1.2 & 1.1 \\
\hline $6-6-2$ & 7 & 43 & 34 & 1.5 & 1.1 \\
\hline $6-6-3$ & 6 & 44 & 40 & 1.2 & 0.4 \\
\hline & & & & & \\
\hline $7-6-1$ & 15 & 32 & 28 & 1.6 & 1.5 \\
\hline $7-6-2$ & 15 & 33 & 29 & 1.1 & 1.6 \\
\hline $7-6-3$ & 15 & 34 & 31 & 2.9 & 1.2 \\
\hline $7-6-4$ & 15 & 36 & 35 & 9.3 & 1.4 \\
\hline $7-6-5$ & 15 & 38 & 32 & 3.7 & 0.7 \\
\hline & & & & & \\
\hline $8-6-1$ & 15 & 44 & 37 & 6.3 & 1.7 \\
\hline $9-6-1$ & 15 & 36 & 27 & 2.1 & 0.7 \\
\hline $9-6-2$ & 15 & 39 & 29 & 0.9 & 0.9 \\
\hline $9-6-3$ & 15 & 42 & 32 & 1.9 & 1.4 \\
\hline & & & & & \\
\hline $10-6-1$ & 15 & 37 & 27 & 2.2 & 1.1 \\
\hline $10-6-2$ & 15 & 39 & 29 & 1.6 & 1.1 \\
\hline $10-6-3$ & 15 & 41 & 31 & 5.1 & 0.8 \\
\hline $10-6-4$ & 15 & 42 & 35 & 6.9 & 1.1 \\
\hline
\end{tabular}

The velocity standard deviation as a result of the uncontrolled temperature conditioning of the charges was plotted to visualize any degradation in precision (muzzle velocity uniformity) as a function of temperature variability within the test group. The data shows that the velocity standard deviation does not correlate well with temperature variability concluding that the effect of temperature variation is not as significant as predicted by prior studies based on bag charge performance. In fact, the effect was so small that it could not be measured because of other system errors (fig. 4). 


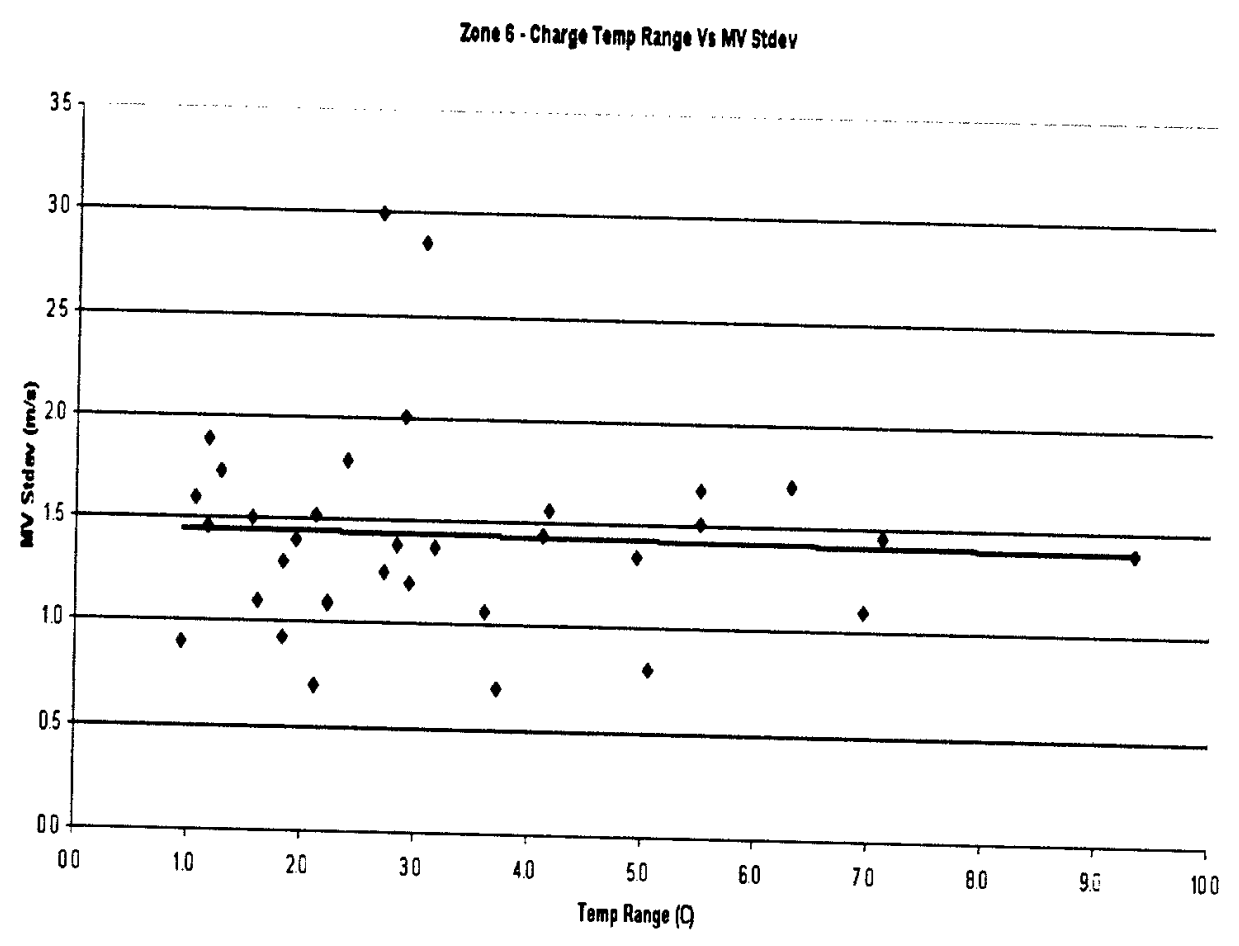

Figure 4

Zone 6 - charge temperature range versus muzzle velocity standard deviation

\section{Summary}

The temperature distribution of a pallet of MACS increments that have been exposed to the desert conditions for more than $24 \mathrm{hrs}$ at the conditions that occurred during the test at Yuma Proving Ground consistently exhibit a low temperature variation $\left(<10^{\circ} \mathrm{C}\right)$ between increments. Pallets of charges subjected to high solar radiation should yield the largest expected temperature variation between charges subjected to the same air temperature. In these tests, the temperature standard deviation of the test groups ranged from $0.3^{\circ} \mathrm{C}$ to $3.3^{\circ} \mathrm{C}$, ture standard deviation $11^{\circ} \mathrm{C}$. It should also be noted that for the one occasion where the temperawas less than $2.0 \mathrm{~m} / \mathrm{s}$. The appendix has details of the test data and analysis.

\section{CONCLUSION}

Charges from pallets stored at the same site where the air temperature is somewhat uniform and that are immediately loaded and fired can be expected to perform satisfactorily with regards to muzzle velocity standard deviation (precision). Subjecting unprotected pallets of charges to prevailing desert conditions without cover showed no adverse impact on precision.

The results of this testing shows that a temperature management system to record individual increment temperatures and any attempt to correct aiming data, based on the individual temperatures, would not result in any improvement in precision when the temperature range is less than $10^{\circ} \mathrm{C}$ under the scenario used in the test. 
The current application of adjusting aiming data for average powder temperature should be continued and not expanded to individual charge temperatures unless firing scenarios are validated where temperature range in charges would exceed $10^{\circ} \mathrm{C}$. Should such scenarios be identified, further testing similar to that described in this report would be recommended prior to implementing an individual charge temperature management system. 
APPENDIX

TEST DATA AND ANALYSIS 
The "test group" was composed of five pallets for a total of 750 MACS M232 propellant charges. PA103A2 containers were numbered 1 through 30 starting from the top left corner and working across starting with the first pallet then 31 to 60 for the second pallet and so forth.

\section{Test Setup}

The test group pallets were subjected to the Yuma Proving Grounds (YPG) natural environment for a minimum of $24 \mathrm{hrs}$. The lid end of the pallet for the test group faced the south/south-west end. The control groups were conditioned in a conditioning chamber for 24 hrs minimum at $21^{\circ} \mathrm{C}$.

In addition to test and control pallets, a pallet of M232 charges was called the "shadow group." The shadow group contained 14 MACS Increment Thermal Emulators (ITEs). The ITEs were inert charges developed specifically to emulate the thermal characteristics of a live M232 charge. Embedded within the ITE is temperature sensing and recording instrumentation. Each ITE records temperature data real time that can be later downloaded via a personal computer. The shadow group was subjected to the same environment as the test charges. The 14 ITE's replaced the charges as follows in the pallet, where A represents the lid end of the can, $C$ represents the middle charge, and $E$ represents the base end of the can (fig. A1). An additional ITE was placed on top of the pallet to record the temperature effect due to solar radiation and insulation provided by the can.
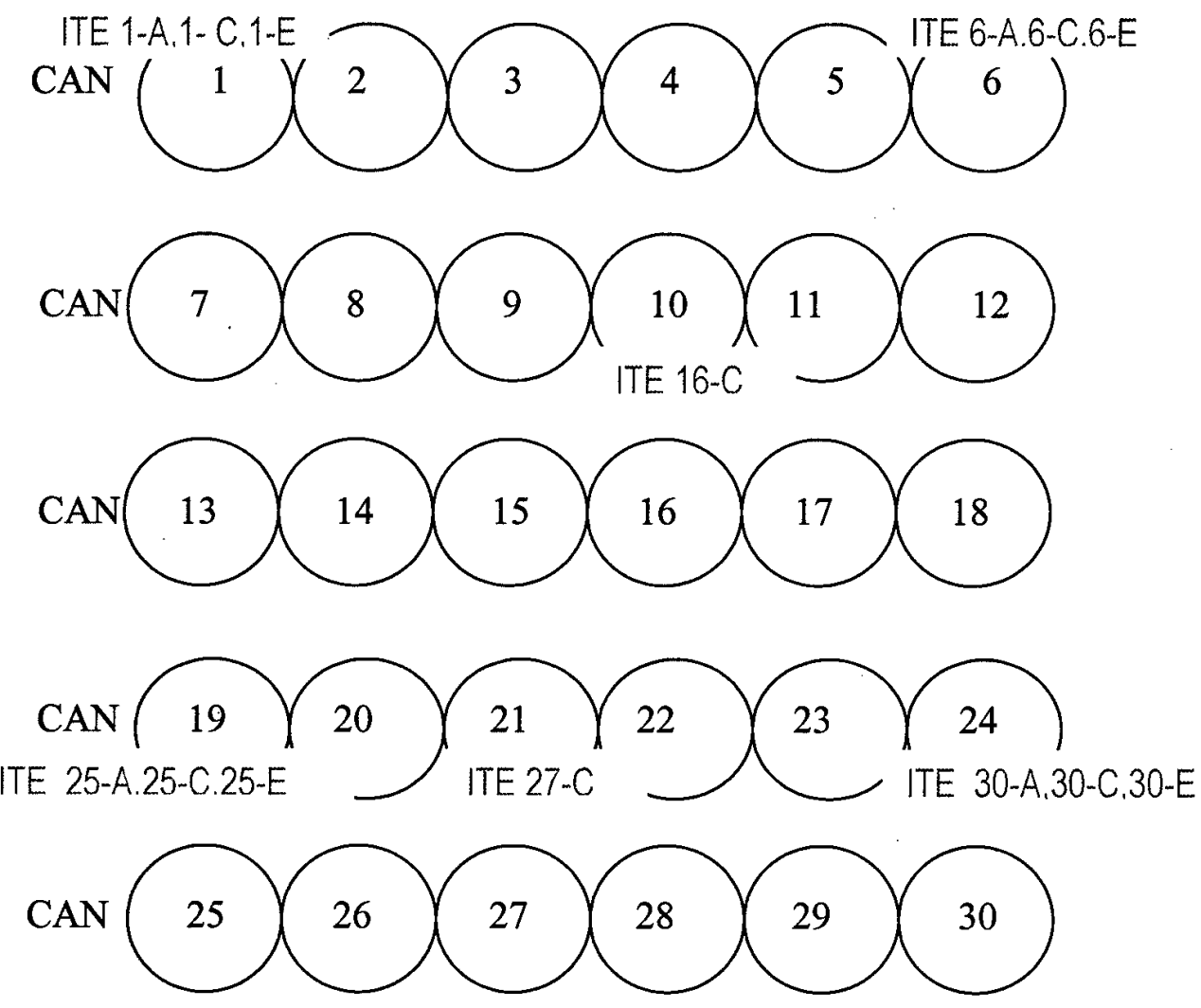

Figure A1

ITE replacements 
The temperature data from the middle ITE for each can with an instrumented charge and the ITE placed on top of the pallet during the time frame of May $21^{\text {st }}$ to May $31^{\text {st }}$ where Phase 1 firings occurred are presented (graphs A1 to A7). Additionally, the delta between the highest recorded ITE temperature and lowest recorded ITE temperature at each time is plotted to present the temperature extremes within a pallet of charges at a particular time (graph A8). 


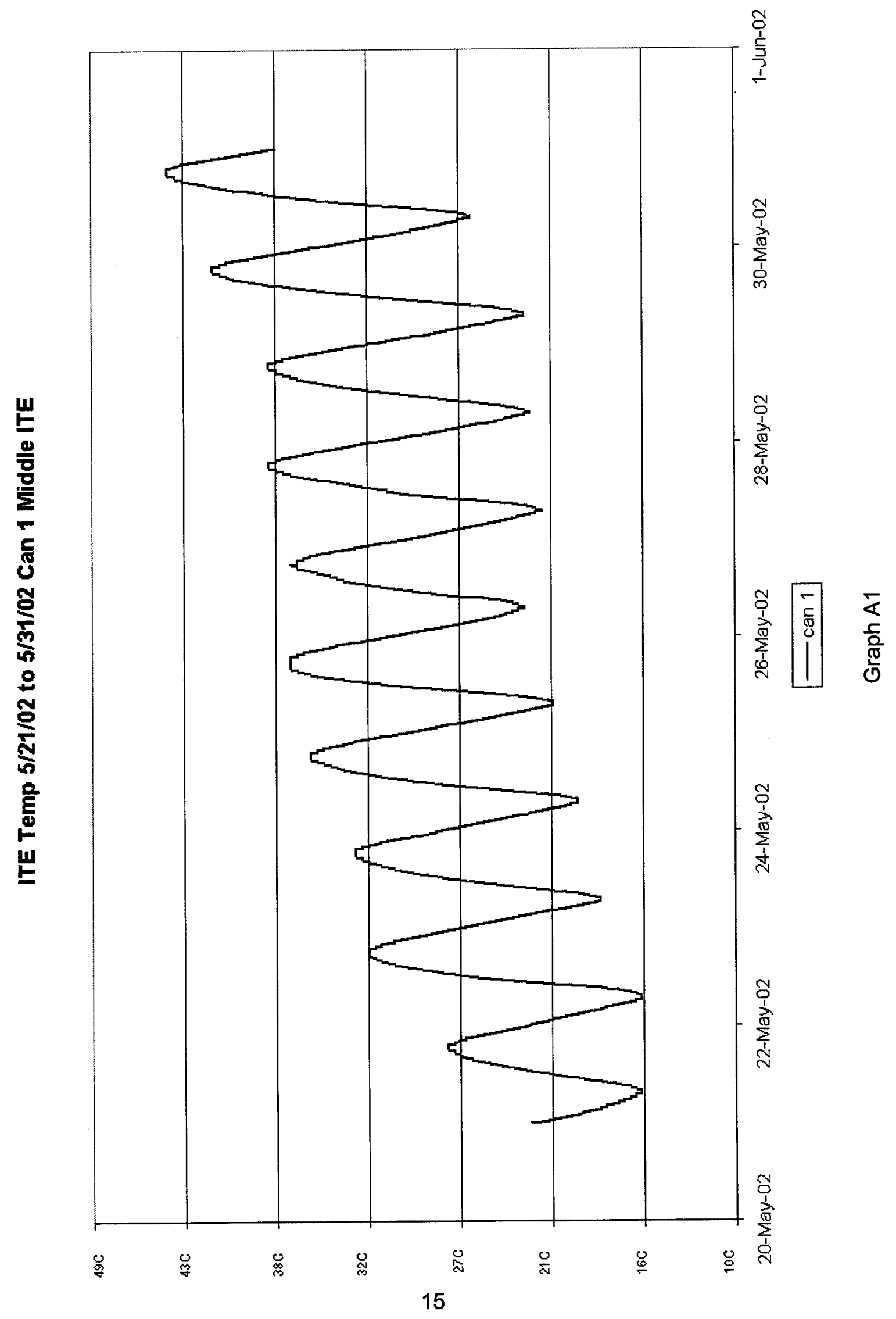




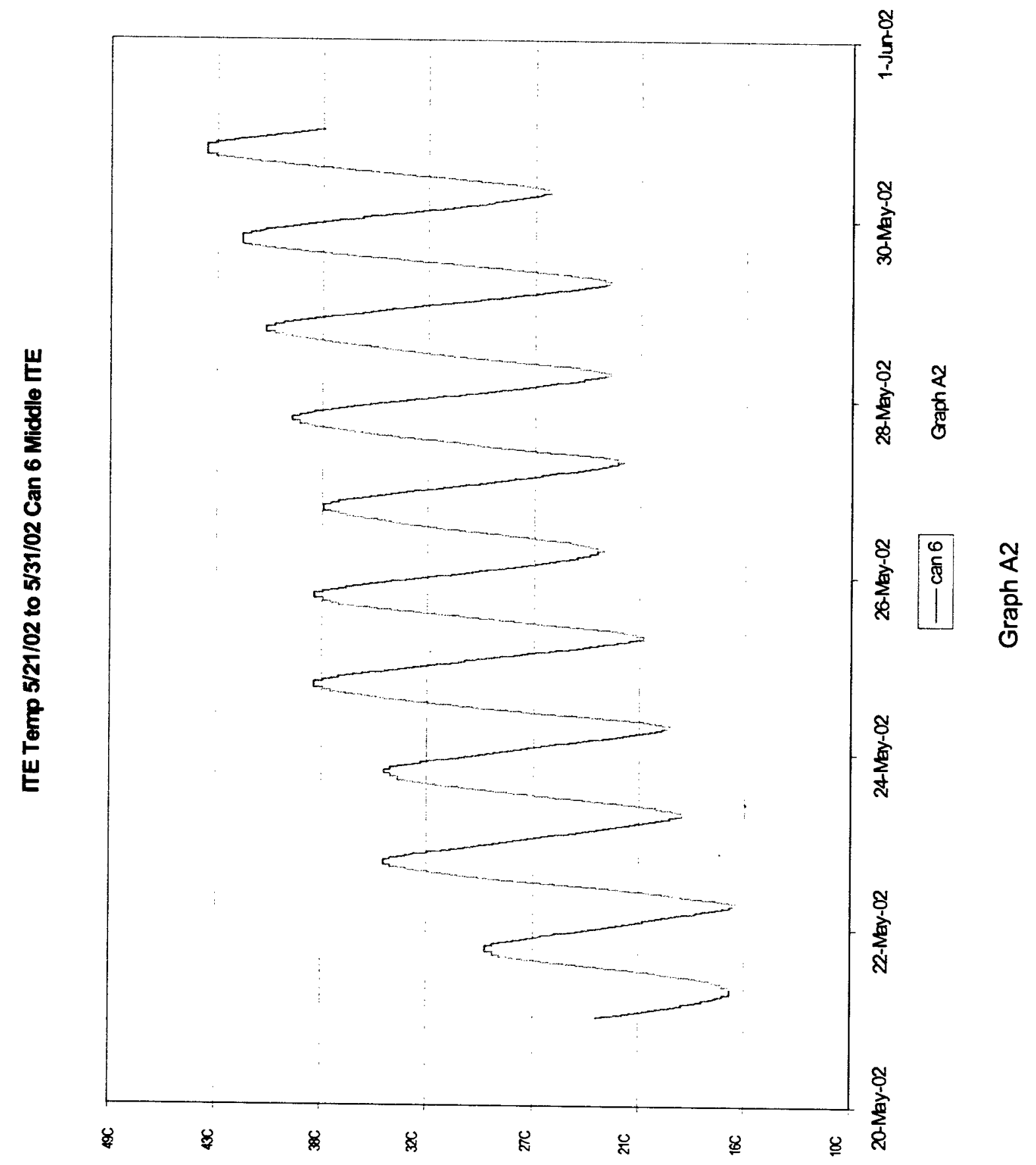




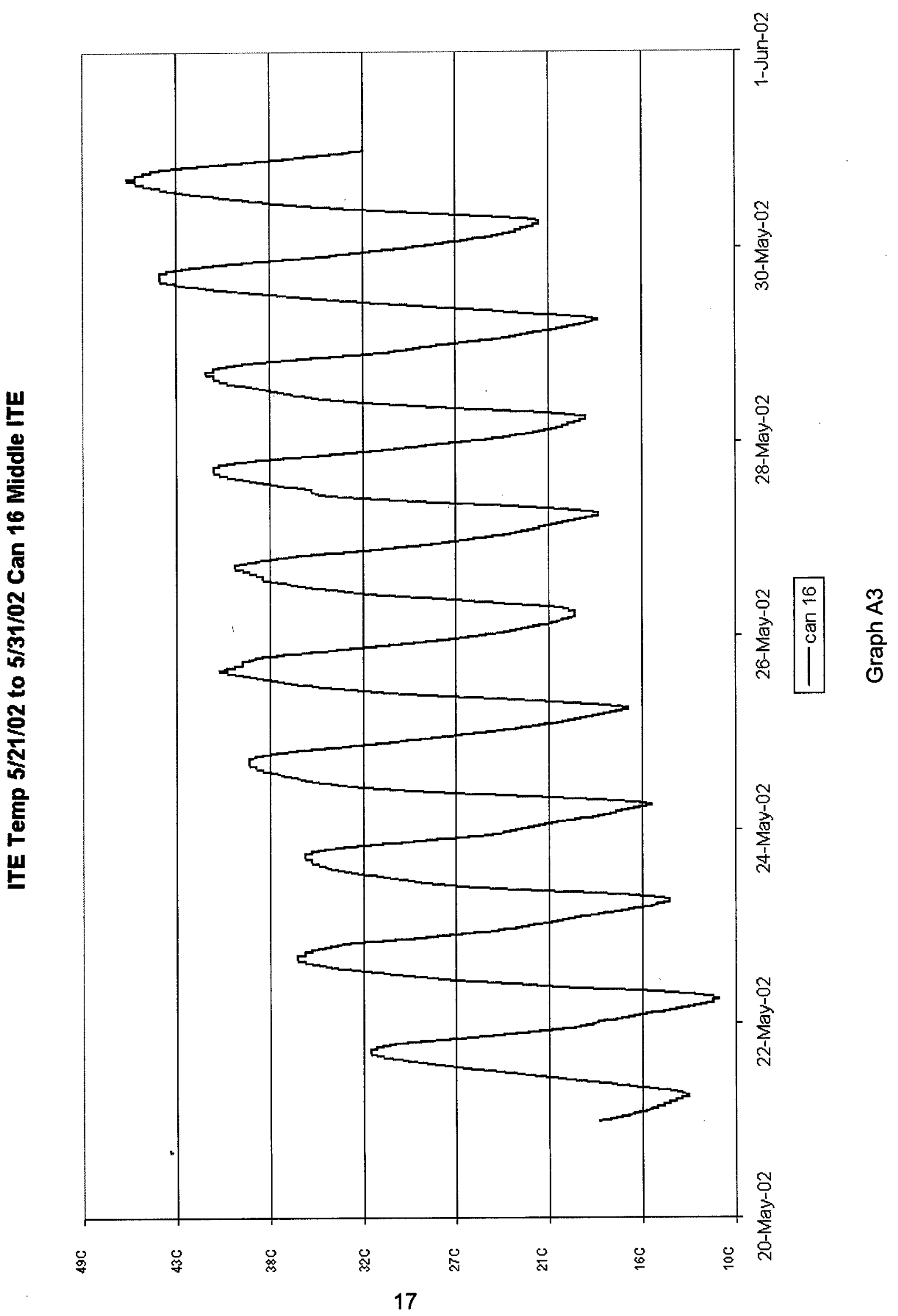




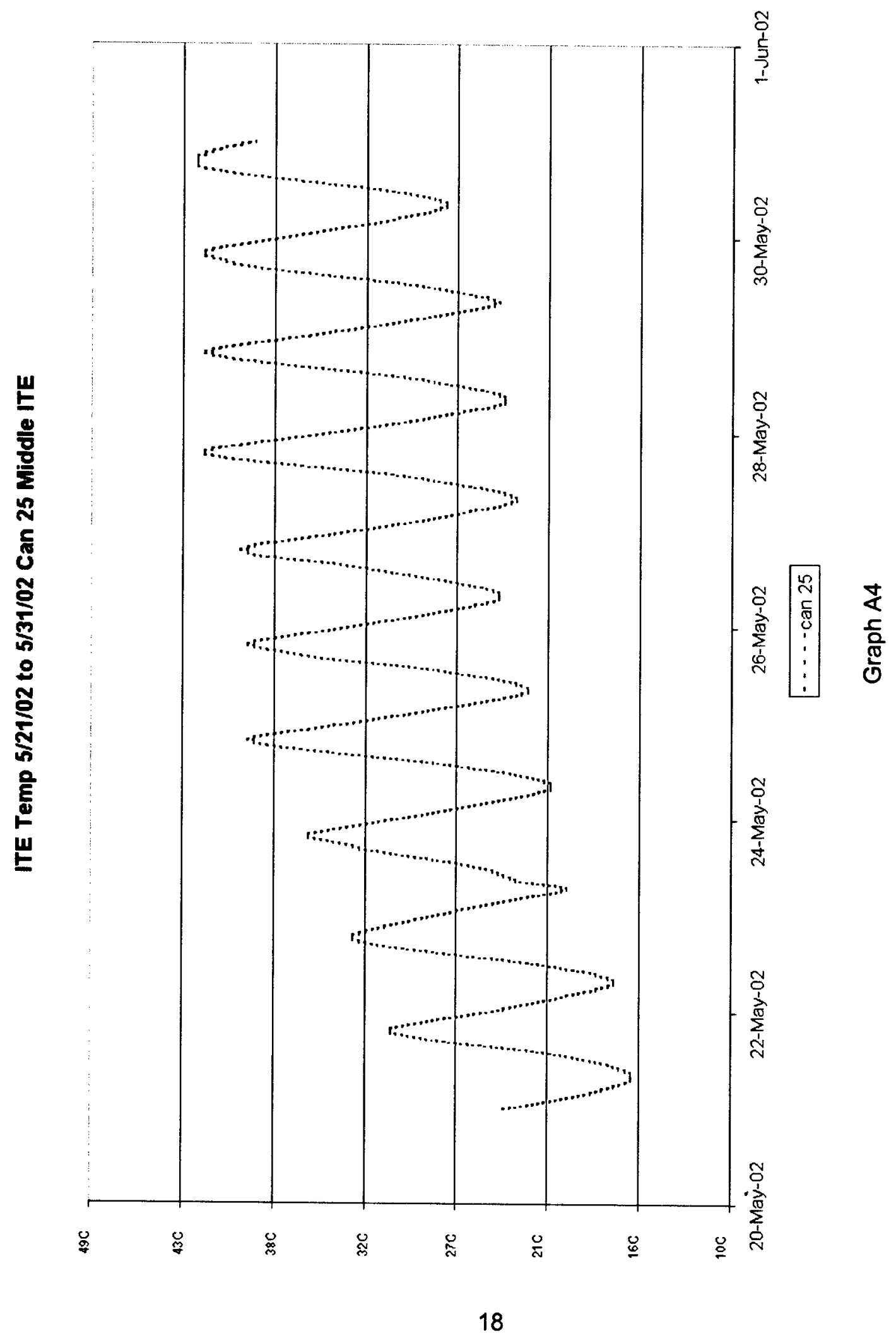




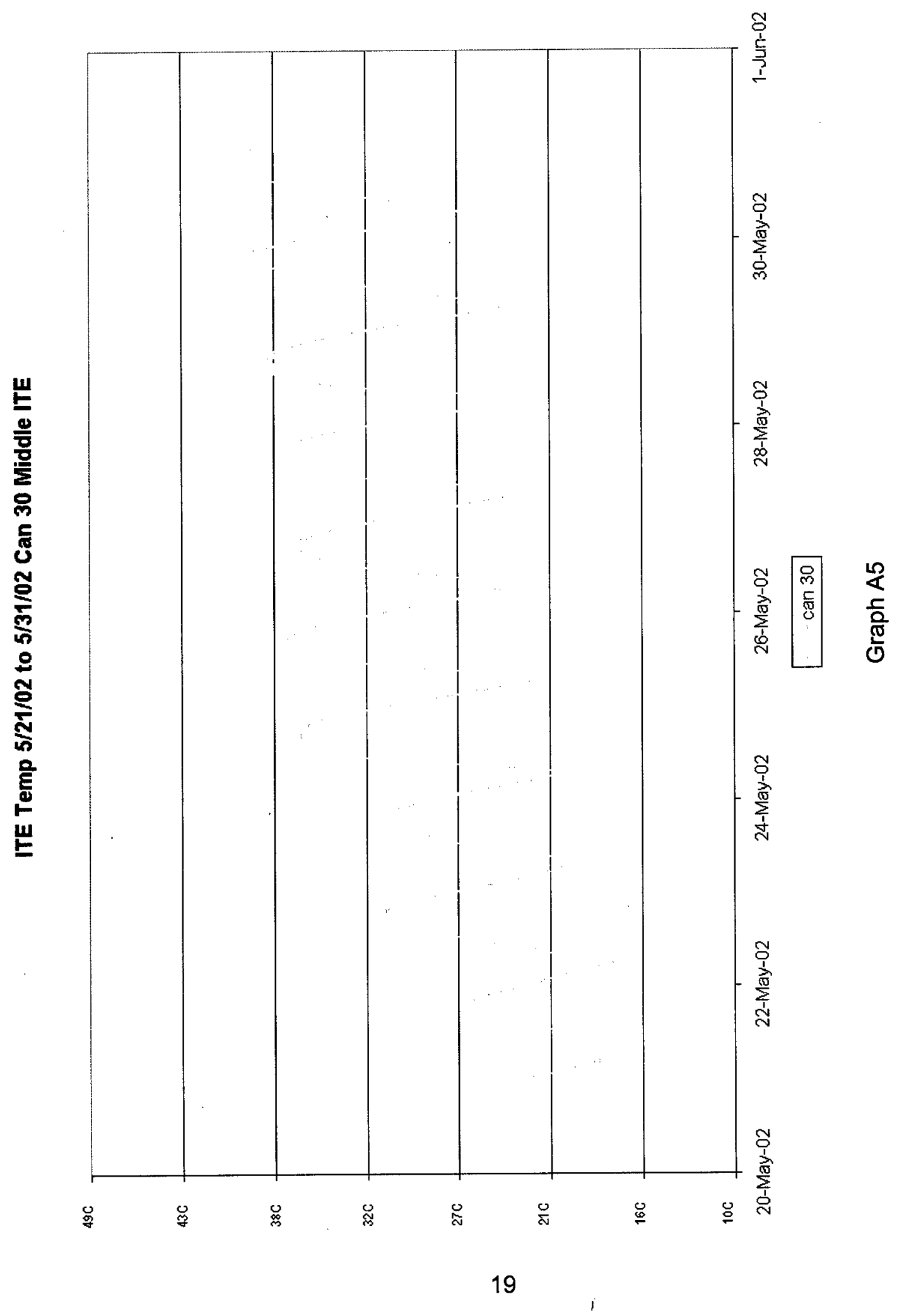




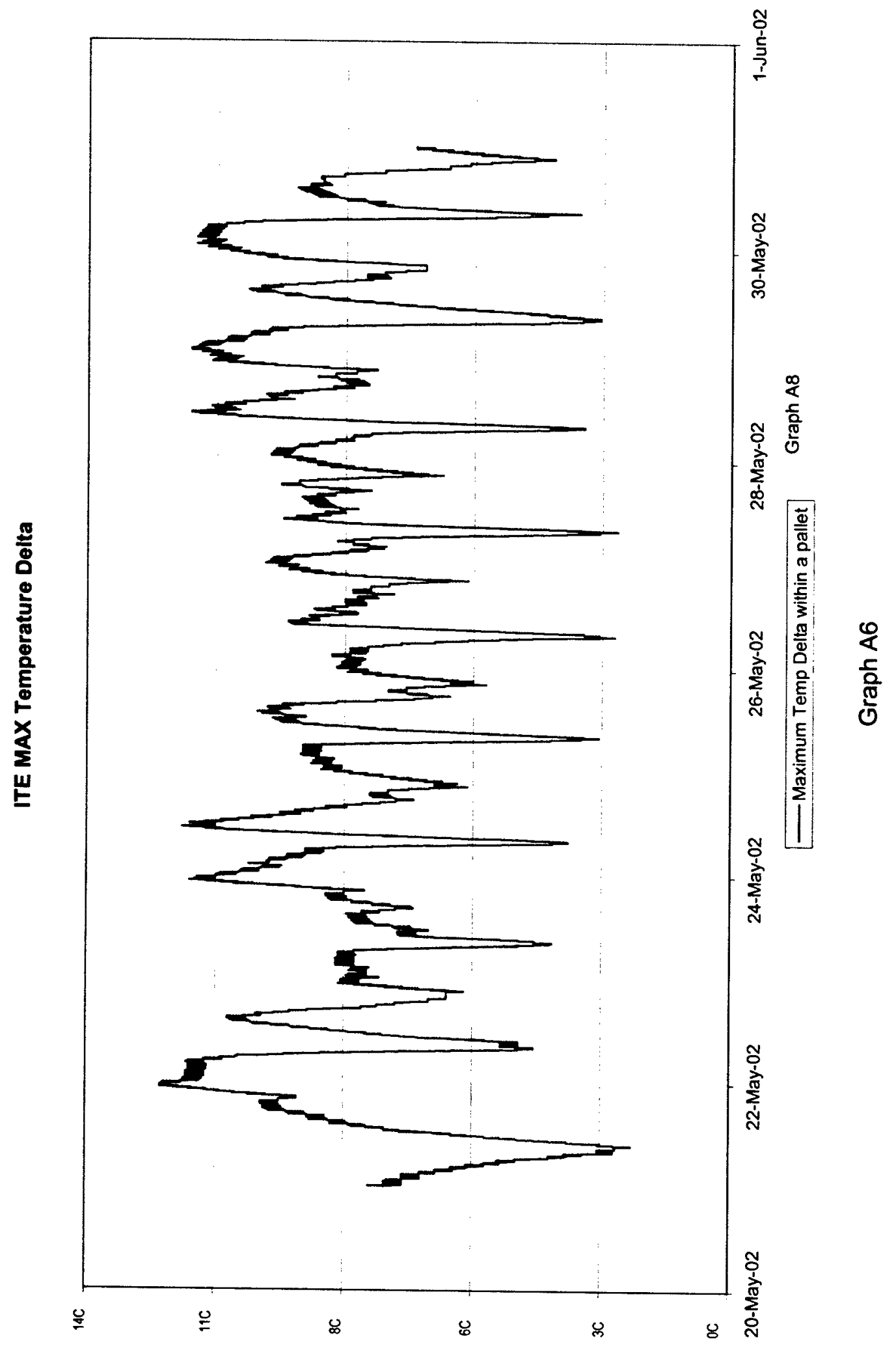




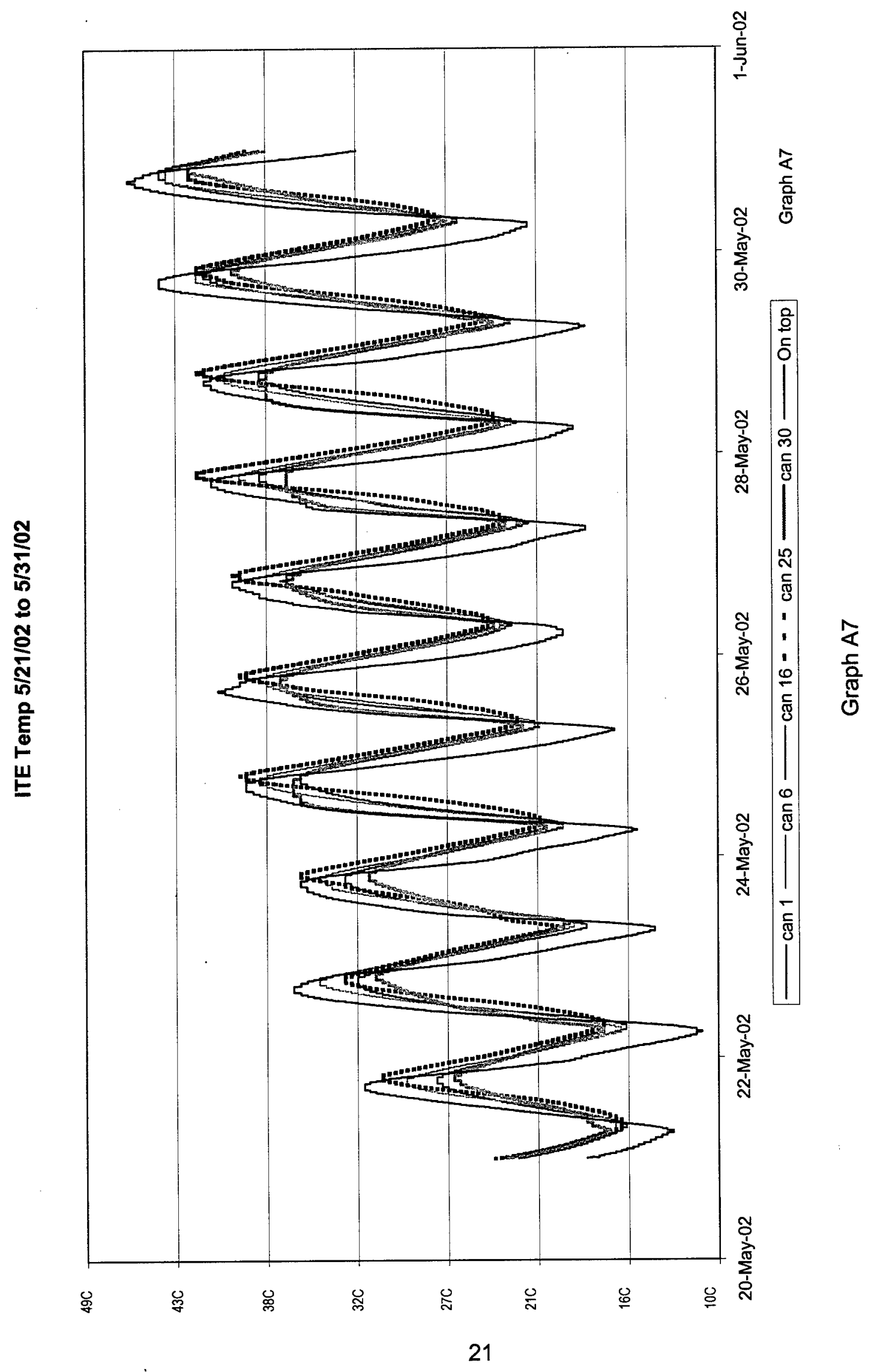




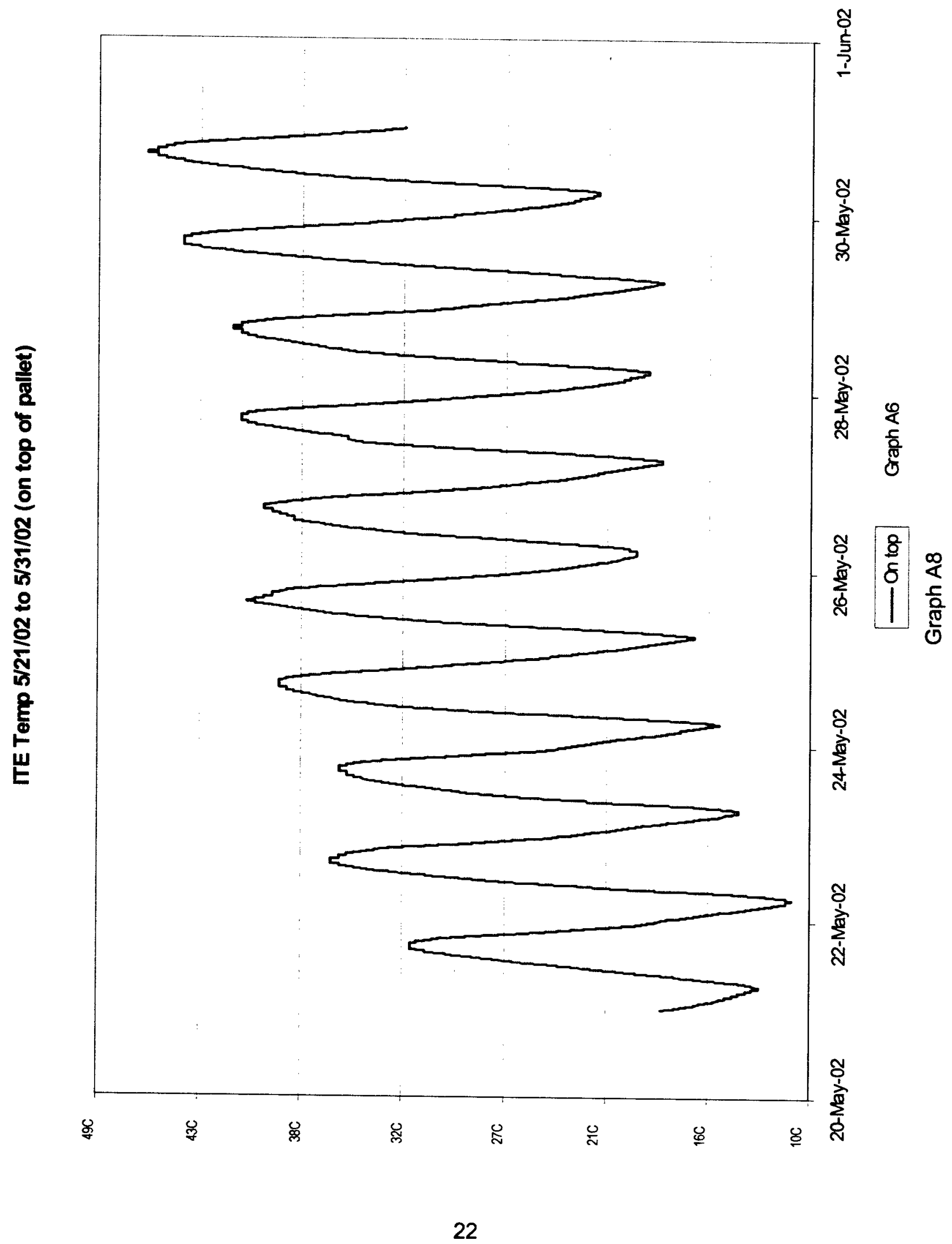


The firing data from phase 1 and phase 2 is summarized here.

- For each occasion, the test group charges were selected from a cross-section of cans across the entire pallet to minimize the uniformity in ambient temperature conditioning. For example, Occasion 3-1, charges from cans 1, 8, 15, 22, 27, and 29 were selected from the pallet.

- To determine the temperature variation within a group of charges, the center core temperature of a sample of charges from each group was measured. For example, Occasion 3-1, temperature data of the first, middle, and end charge of can 1 and the middle charge of can 27 were collected.

- To determine the effect of temperature on muzzle velocity (MV) for an individual round within a group, the average muzzle velocity for each group was calculated. The deviation of the MV for the individual round from the average MV was calculated and presented in the following tables. For phase 1, similar calculations are presented for the control groups.

- The graphs show the deviation of the individual MV from the average MV.

- $\quad$ Additionally, for each group, the mean absolute deviation (MAD) was calculated and presented at the bottom of each table.

$$
M A D=\frac{\sum|X-u|}{N}
$$

where $\Sigma|X-\mu|$ is the sum of the absolute differences between each observed sample value, $X$ and the sample mean $\mu$, while $N$ is the number of observations in the sample.

- No difference was noted in the mean absolute deviation between the test and control groups for phase 1. 


\section{Phase 1}

Zone 3- Occasion 1
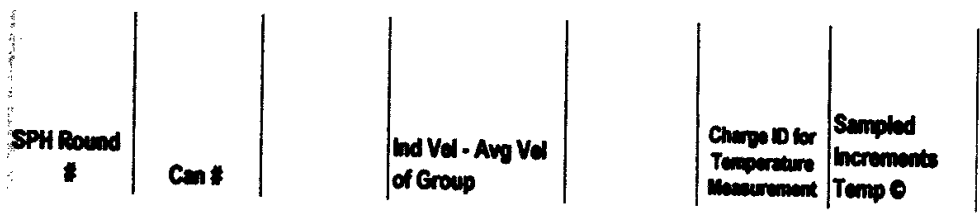

Test Group

\begin{tabular}{|c|c|c|c|}
\hline 6324 & 1 & 5963 & 3.9 \\
\hline 6325 & 8 & 5938 & 1.4 \\
\hline 6326 & 15 & 5921 & -0.3 \\
\hline 6327 & 22 & 592.4 & 0.0 \\
\hline 6328 & 27 & 591.9 & -0.5 \\
\hline 6329 & 29 & 592.9 & 0.5 \\
\hline 6330 & & 5911 & -1.3 \\
\hline 6331 & & 5912 & -1.2 \\
\hline 6332 & & 5906 & -1.8 \\
\hline 6333 & & 5917 & -0.7 \\
\hline & & & \\
\hline & & & 1.2 \\
\hline
\end{tabular}

\begin{tabular}{|c|c|}
\hline $1 \mathrm{~A}$ & 20.7 \\
\hline $1 \mathrm{C}$ & 19.8 \\
\hline $1 \mathrm{E}$ & 20.0 \\
\hline $27 \mathrm{C}$ & 18.2 \\
\hline
\end{tabular}

Control Group
\begin{tabular}{|c|c|c|c|}
\hline 6334 & & & 1.1 \\
\hline 6335 & & & 2.2 \\
\hline 6336 & & & -1.0 \\
\hline 6337 & & & -0.4 \\
\hline 6338 & & & -1.0 \\
\hline 6339 & & & 1.2 \\
\hline 6340 & & & 0.4 \\
\hline 6341 & & & -1.5 \\
\hline 6342 & & & -0.1 \\
\hline 6343 & & & -1.2 \\
\hline & & & \\
\hline MAD & & 1.0 \\
\hline
\end{tabular}

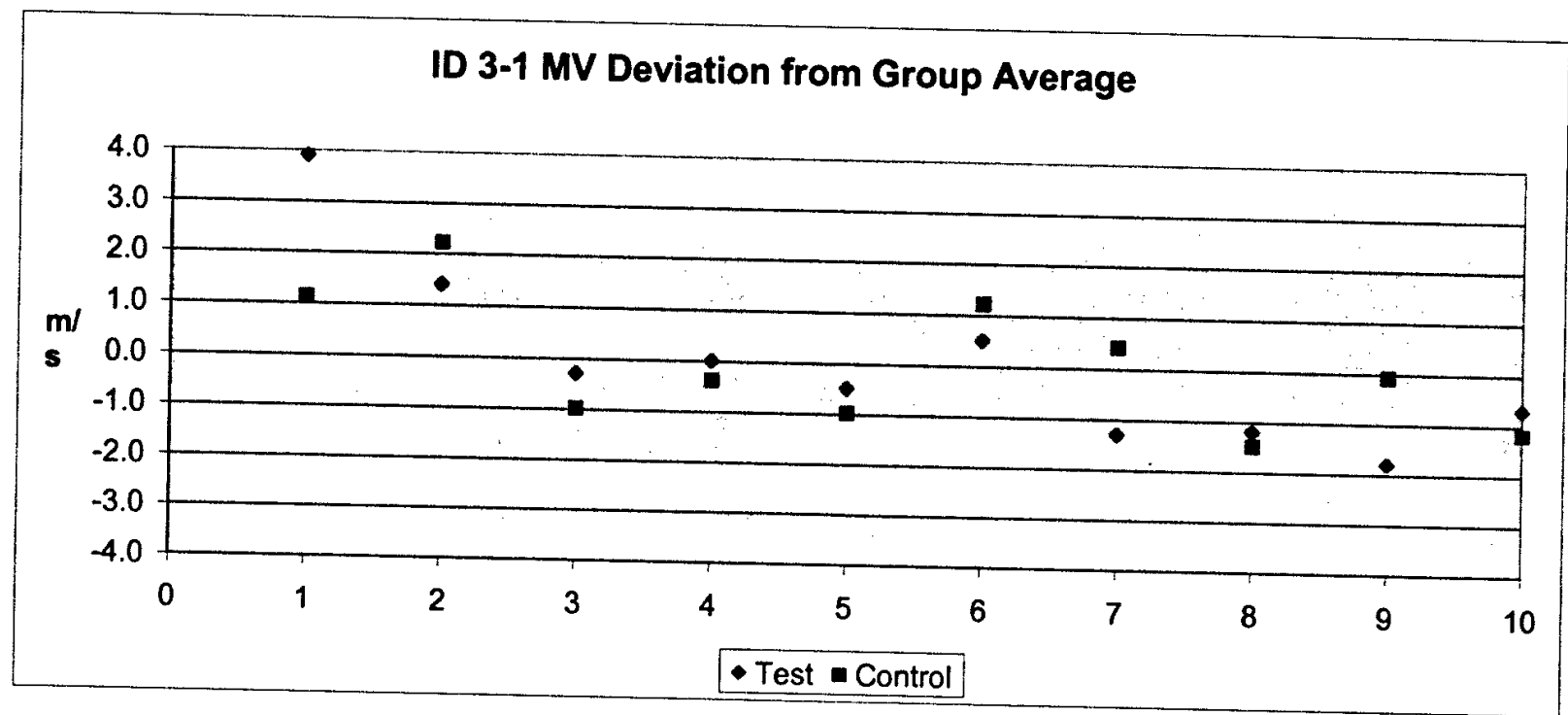


Zone 3 - Occasion 2

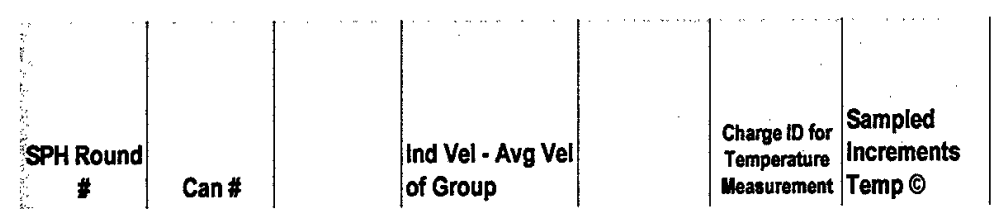

Test Group
\begin{tabular}{|c|c|c|c|}
\hline 6393 & 3 & 589.8 & -1.4 \\
\hline 6394 & 8 & 590.5 & -0.7 \\
\hline 6395 & 15 & 591.2 & 0.0 \\
\hline 6396 & 22 & 589.0 & -2.2 \\
\hline 6397 & 26 & 592.0 & 0.8 \\
\hline 6398 & 30 & 591.5 & 0.3 \\
\hline 6399 & & 593.0 & 1.8 \\
\hline 6400 & & 592.1 & 0.9 \\
\hline 6401 & & 590.9 & -0.3 \\
\hline 6402 & & 592.2 & 1.0 \\
\hline & & & \\
\hline
\end{tabular}

\begin{tabular}{|l|l|}
\hline $30 \mathrm{~A}$ & 28.3 \\
\hline $30 \mathrm{~B}$ & 27.8 \\
\hline $30 \mathrm{C}$ & 28.8 \\
\hline
\end{tabular}

Control Group
\begin{tabular}{|c|c|c|c|}
\hline 6383 & & & 4.9 \\
\hline 6384 & & & 2.5 \\
\hline 6385 & & & 2.1 \\
\hline 6386 & & & 0.4 \\
\hline 6387 & & & -1.6 \\
\hline 6388 & & & 0.3 \\
\hline 6389 & & & -1.5 \\
\hline 6390 & & & -1.7 \\
\hline 6391 & & & -3.5 \\
\hline 6392 & & & -1.6 \\
\hline & & & \\
\hline MAD & & 2.0 \\
\hline
\end{tabular}

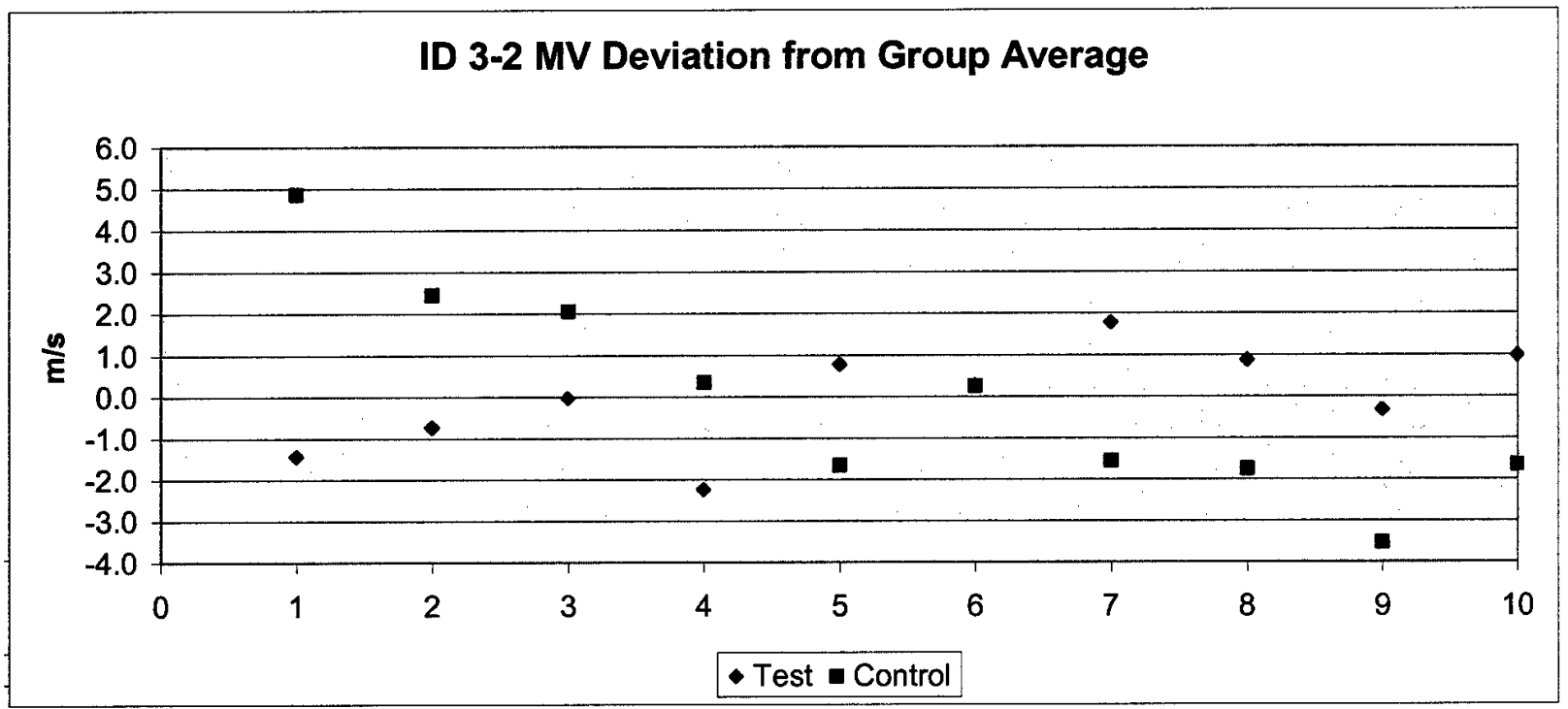


Zone 3 - Occasion 3
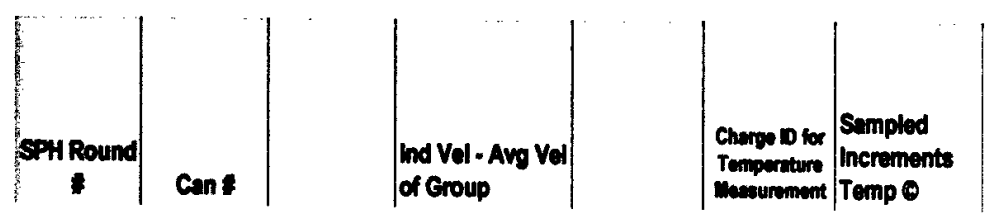

Test Group

\begin{tabular}{|l|c|c|c|}
\hline 6473 & 3 & 593.3 & 1.4 \\
\hline 6474 & 6 & 592.5 & 0.6 \\
\hline 6475 & 15 & 592.5 & 0.6 \\
\hline 6476 & 22 & 591.5 & -0.4 \\
\hline 6477 & 26 & 593.0 & 1.1 \\
\hline 6478 & 29 & 593.1 & 1.2 \\
\hline 6479 & & 590.6 & -1.3 \\
\hline 6480 & & 591.6 & -0.3 \\
\hline 6481 & & 591.0 & -0.9 \\
\hline 6482 & & 589.9 & -2.0 \\
\hline & & & \\
\hline \multicolumn{2}{|c|}{ MAD } & & 1.0 \\
\hline
\end{tabular}

\begin{tabular}{|l|l|}
\hline $6 \mathrm{~A}$ & 40.9 \\
\hline $6 \mathrm{C}$ & 39.9 \\
\hline $6 \mathrm{E}$ & 39.6 \\
\hline
\end{tabular}

\section{Control Group}

\begin{tabular}{|c|c|c|c|}
\hline 6463 & & & 3.7 \\
\hline 6464 & & & 1.6 \\
\hline 6465 & & & 2.5 \\
\hline 6466 & & & 1.0 \\
\hline 6467 & & & -0.4 \\
\hline 6468 & & & -1.8 \\
\hline 6469 & & & -2.3 \\
\hline 6470 & & & -1.0 \\
\hline 6471 & & & -1.6 \\
\hline 6472 & & & -1.0 \\
\hline & & & \\
\hline \multicolumn{2}{|c|}{ MAD } & & 1.7 \\
\hline
\end{tabular}

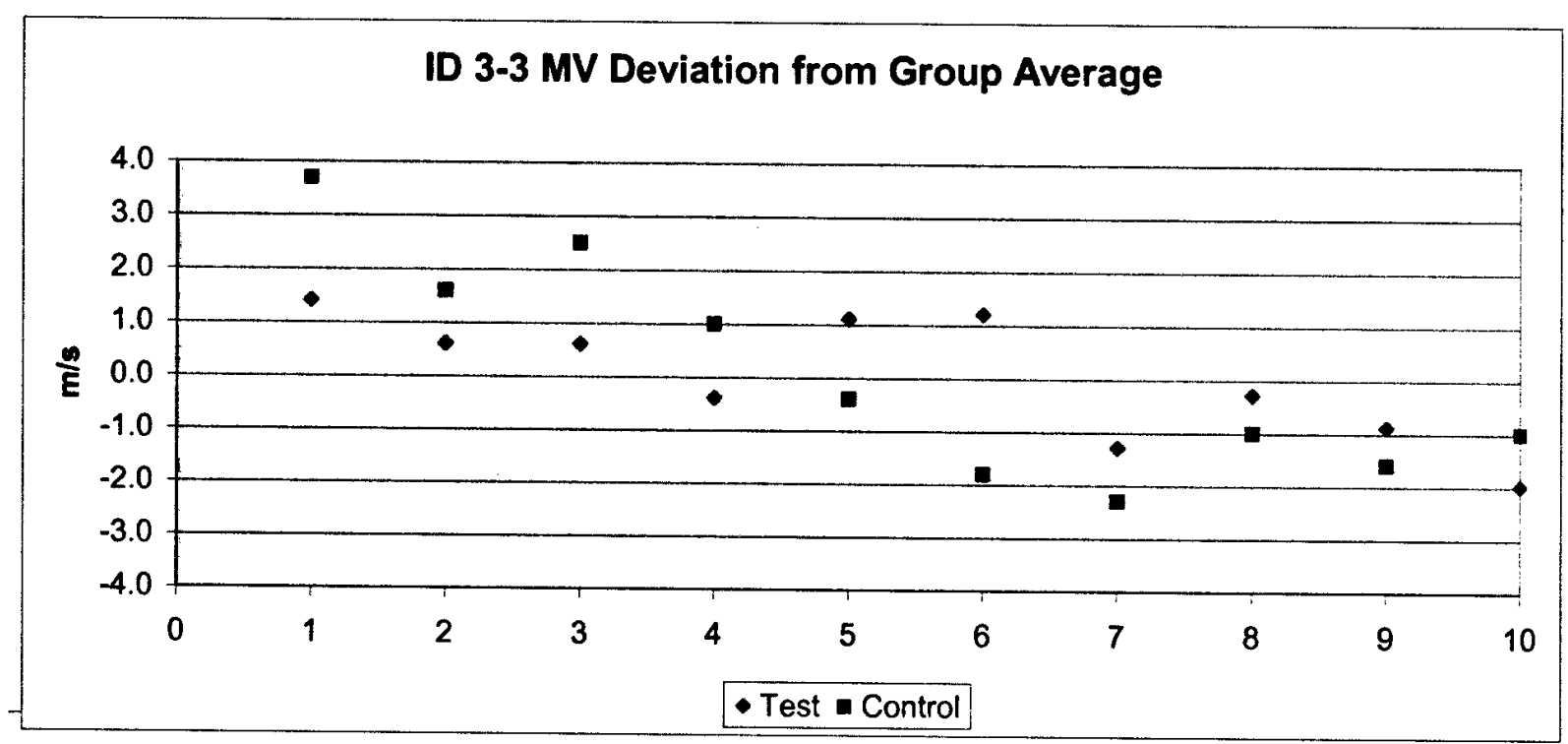


Zone 4 - Occasion 1
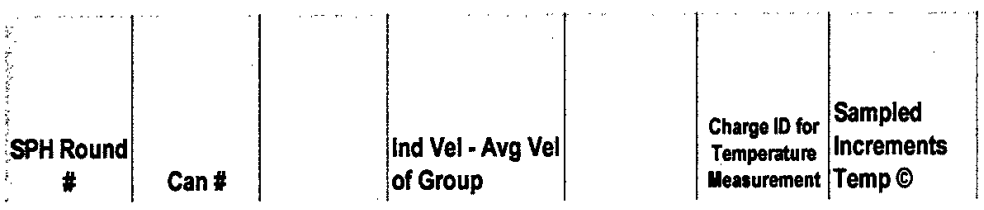

Test Group

\begin{tabular}{|c|c|c|c|}
\hline 6344 & 2 & 721.0 & -1.6 \\
\hline 6345 & 5 & 722.8 & 0.2 \\
\hline 6346 & 9 & 723.3 & 0.7 \\
\hline 6347 & 13 & 722.9 & 0.3 \\
\hline 6348 & 16 & 724.5 & 1.9 \\
\hline 6349 & 23 & 722.1 & -0.5 \\
\hline 6350 & 26 & 723.2 & 0.6 \\
\hline 6351 & 30 & 721.4 & -1.2 \\
\hline 6352 & & 723.5 & 0.9 \\
\hline 6353 & & 721.9 & -0.7 \\
\hline & & & \\
\hline \multicolumn{2}{|c|}{ MAD } & & 0.9 \\
\hline
\end{tabular}

\begin{tabular}{|l|l|}
\hline $16 \mathrm{C}$ & 22.4 \\
\hline $30 \mathrm{~A}$ & 27.8 \\
\hline $30 \mathrm{~B}$ & 26.4 \\
\hline $30 \mathrm{C}$ & 28.3 \\
\hline
\end{tabular}

Control Group
\begin{tabular}{|c|c|c|c|}
\hline 6354 & & & 0.6 \\
\hline 6355 & & & 0.1 \\
\hline 6356 & & & 0.5 \\
\hline 6357 & & & 0.1 \\
\hline 6358 & & & -0.6 \\
\hline 6359 & & & 2.6 \\
\hline 6360 & & & -0.3 \\
\hline 6361 & & & -1.0 \\
\hline 6362 & & & -1.7 \\
\hline 6363 & & & -0.1 \\
\hline & & & \\
\hline MAD & & 0.8 \\
\hline
\end{tabular}

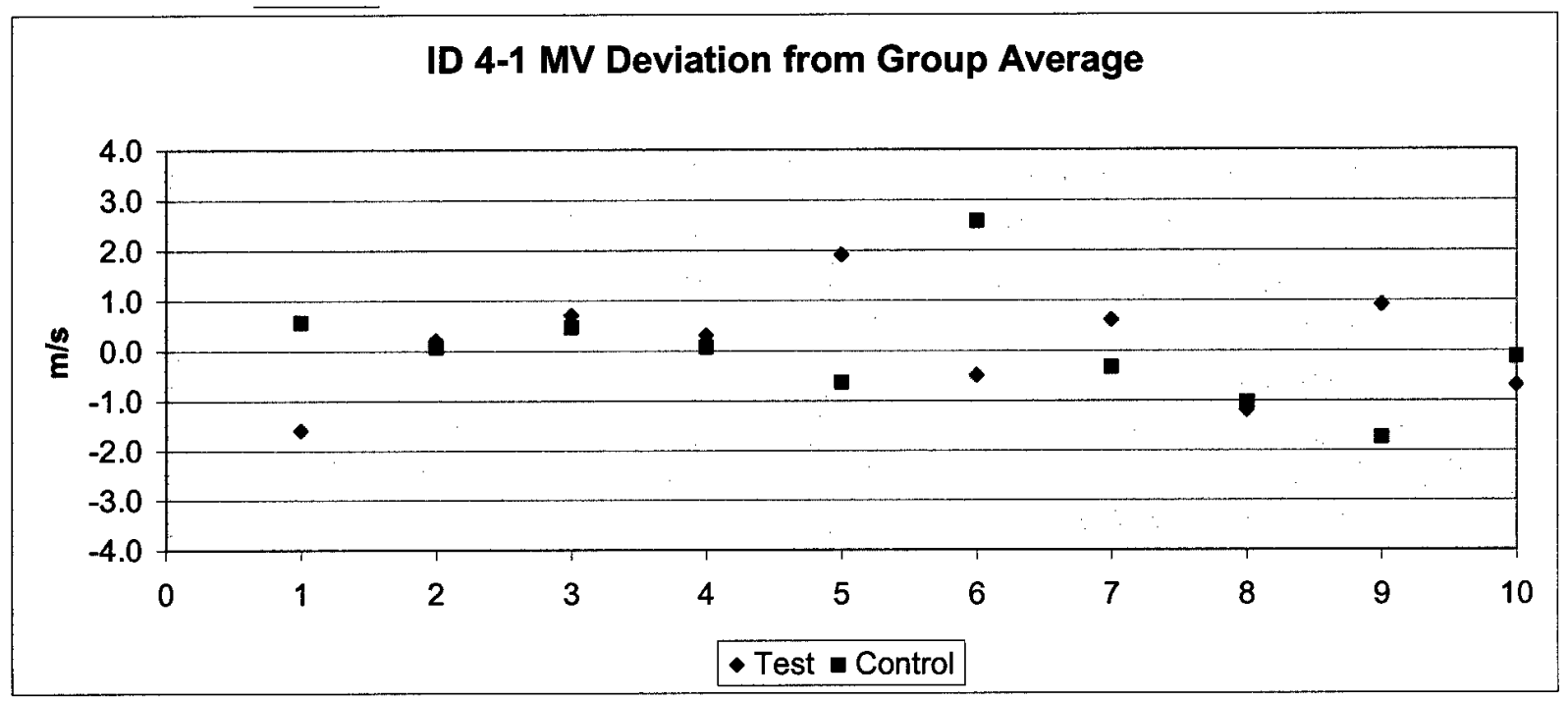


Zone 4 - Occasion 2

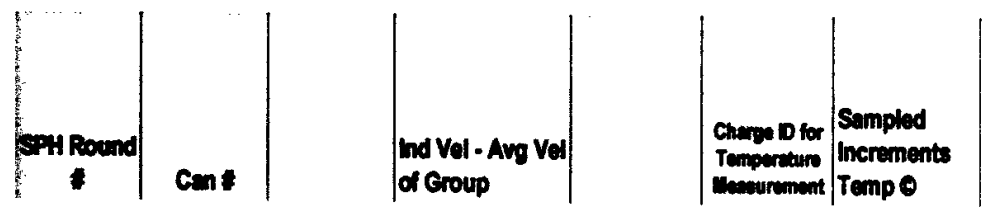

Test Group

\begin{tabular}{|c|c|c|c|}
\hline 6413 & 1 & 719.4 & -1.2 \\
\hline 6414 & 2 & 721.6 & 1.0 \\
\hline 6415 & 5 & 722.5 & 1.9 \\
\hline 6416 & 9 & 720.6 & 0.0 \\
\hline 6417 & 13 & 721.3 & 0.7 \\
\hline 6418 & 18 & 720.4 & -0.2 \\
\hline 6419 & 23 & 719.8 & -0.8 \\
\hline 6420 & 27 & 720.7 & 0.1 \\
\hline 6421 & & 721.1 & 0.5 \\
\hline 6422 & & 718.4 & -2.2 \\
\hline & & & \\
\hline \multicolumn{2}{|c|}{ MAD } & & 0.9 \\
\hline
\end{tabular}

\begin{tabular}{|c|c|}
\hline $1 \mathrm{~A}$ & 28.8 \\
\hline $1 \mathrm{C}$ & 28.6 \\
\hline $1 \mathrm{E}$ & 29.2 \\
\hline $27 \mathrm{C}$ & 28.9 \\
\hline
\end{tabular}

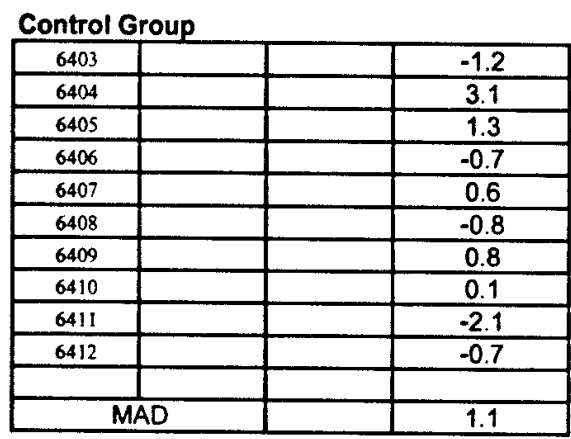

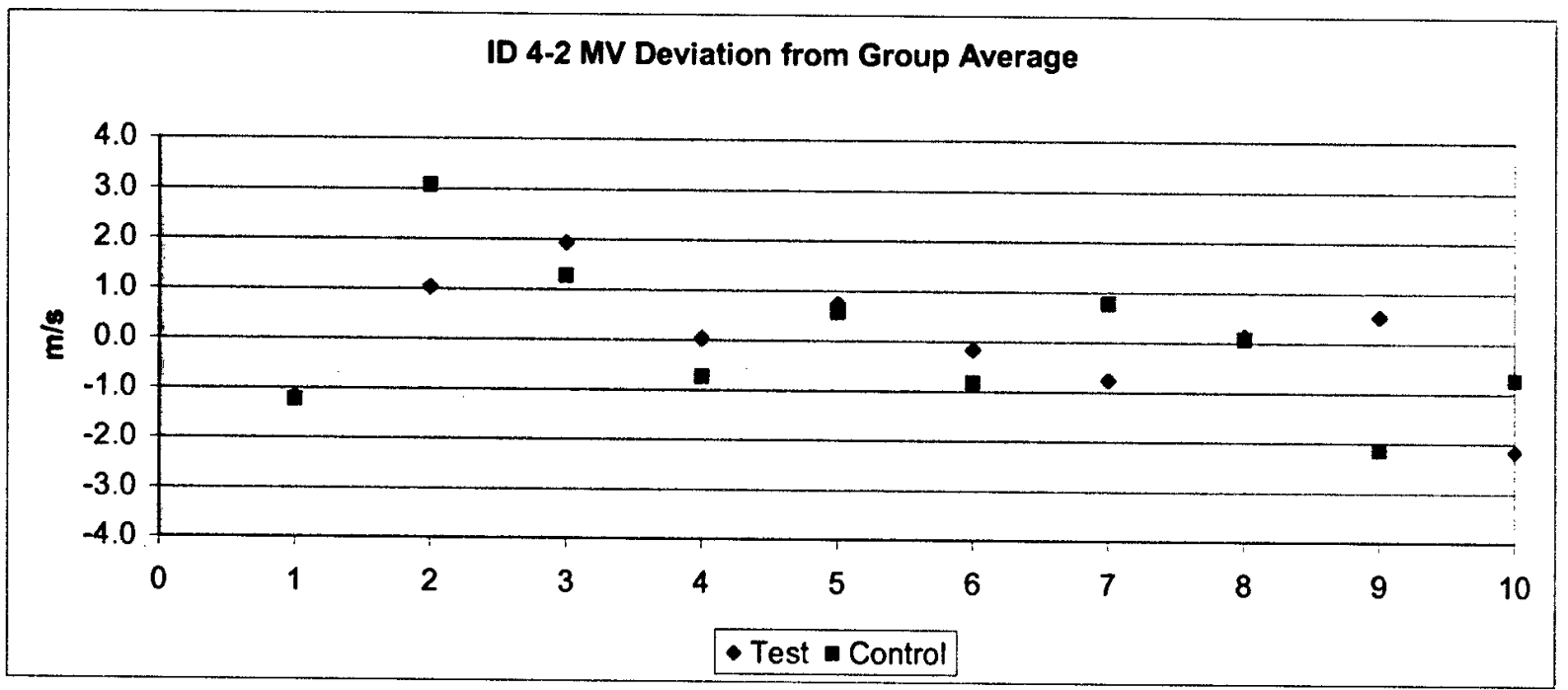


Zone 5 - Occasion 1

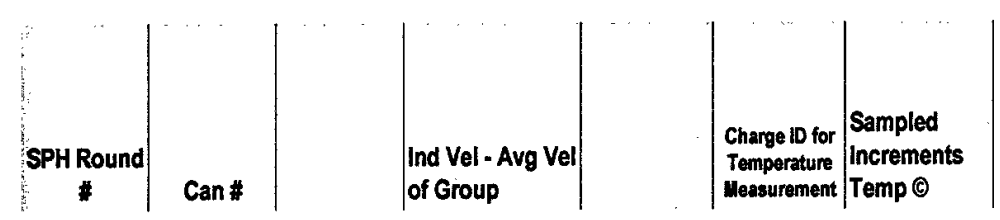

Test Group

\begin{tabular}{|c|c|c|c|}
\hline 6364 & 3 & 848.9 & 2.0 \\
\hline 6365 & 6 & 846.8 & -0.1 \\
\hline 6366 & 10 & 846.1 & -0.8 \\
\hline 6367 & 12 & 845.1 & -1.8 \\
\hline 6368 & 14 & 847.8 & 0.9 \\
\hline 6369 & 18 & 846.5 & -0.4 \\
\hline 6370 & 19 & 848.2 & 1.3 \\
\hline 6371 & 21 & 843.1 & -3.8 \\
\hline 6372 & 24 & 848.8 & 1.9 \\
\hline 6373 & 28 & 847.8 & 0.9 \\
\hline & & & \\
\hline MAD & & 1.4 \\
\hline
\end{tabular}

\begin{tabular}{|c|c|}
\hline $6 \mathrm{~A}$ & 30.7 \\
\hline $6 \mathrm{C}$ & 29.4 \\
\hline $6 \mathrm{E}$ & 29.7 \\
\hline
\end{tabular}

Control Group

\begin{tabular}{|c|c|c|c|}
\hline 6374 & & & 1.3 \\
\hline 6375 & & & 2.2 \\
\hline 6376 & & & -0.4 \\
\hline 6377 & & & -0.9 \\
\hline 6378 & & & -3.2 \\
\hline 6379 & & & -0.4 \\
\hline 6380 & & & 0.2 \\
\hline 6381 & & & -0.3 \\
\hline 6382 & & & 0.4 \\
\hline 6383 & & & 1.1 \\
\hline & & & \\
\hline \multicolumn{2}{|c|}{ MAD } & & 1.0 \\
\hline
\end{tabular}

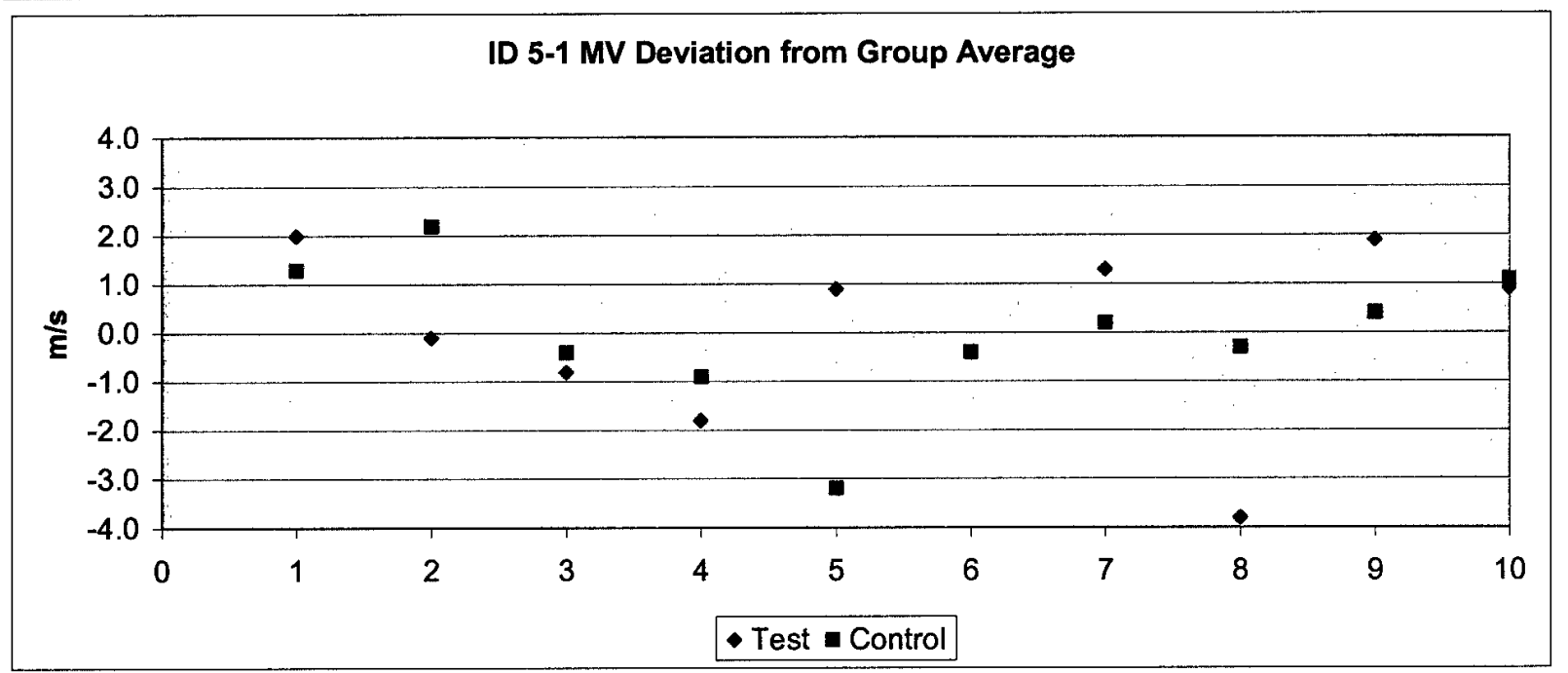


Zone 5 - Occasion 2

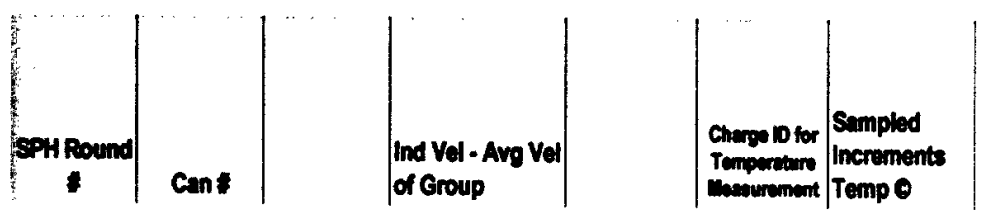

\section{Test Group}

\begin{tabular}{|c|c|c|c|}
\hline 6453 & 7 & 848.3 & -1.0 \\
\hline 6454 & 10 & 846.7 & -2.6 \\
\hline 6455 & 12 & 849.4 & 0.1 \\
\hline 6456 & 14 & 849.9 & 0.6 \\
\hline 6457 & 19 & 850.6 & 1.3 \\
\hline 6458 & 21 & 849.3 & 0.0 \\
\hline 6459 & 24 & 847.1 & -2.2 \\
\hline 6460 & 25 & 848.0 & -1.3 \\
\hline 6461 & 28 & 851.1 & 1.8 \\
\hline 6462 & 29 & 852.4 & 3.1 \\
\hline & & & \\
\hline \multicolumn{2}{|c|}{ MAD } & & 1.4 \\
\hline
\end{tabular}

\begin{tabular}{|l|l|}
\hline $25 \mathrm{~A}$ & 36.8 \\
\hline $25 \mathrm{C}$ & 35.1 \\
\hline $25 \mathrm{E}$ & 36.1 \\
\hline
\end{tabular}

\section{Control Group}

\begin{tabular}{|c|c|c|c|}
\hline 6463 & & & 4.6 \\
\hline 6464 & & & 1.4 \\
\hline 6465 & & & -0.3 \\
\hline 6466 & & & -0.5 \\
\hline 6467 & & & 0.7 \\
\hline 6468 & & & 1.0 \\
\hline 6469 & & & -0.2 \\
\hline 6470 & & & -5.3 \\
\hline 6471 & & & 0.4 \\
\hline 6472 & & & -1.9 \\
\hline & & & \\
\hline MAD & & 1.6 \\
\hline
\end{tabular}

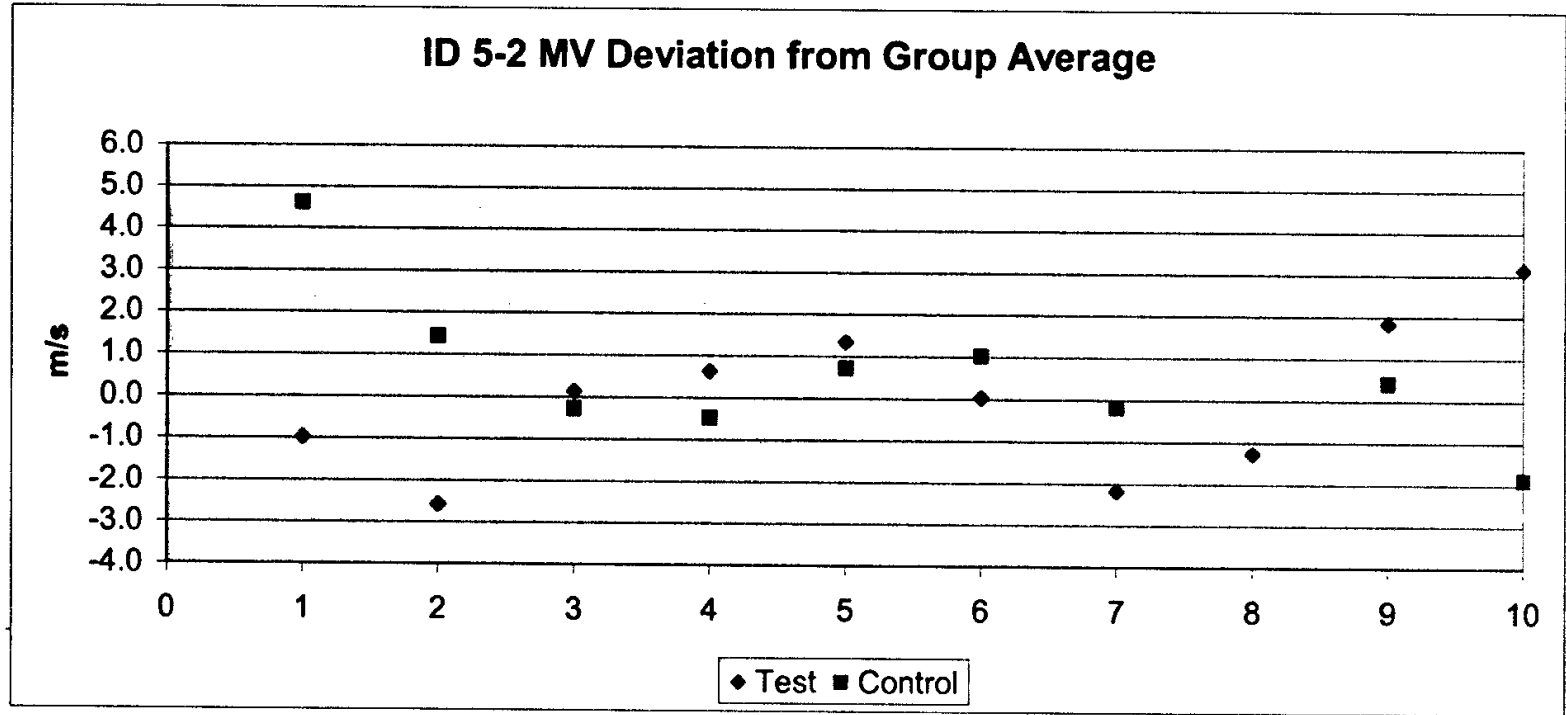


Zone 5 - Occasion 3

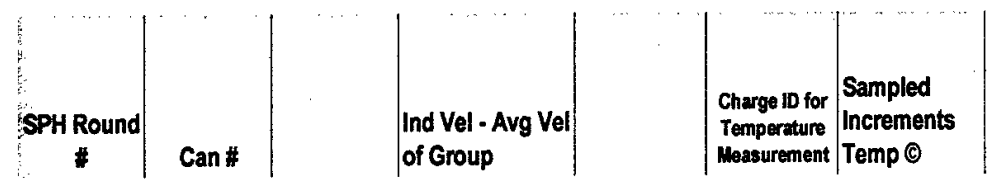

Test Group

\begin{tabular}{|c|c|c|c|}
\hline 6413 & 1 & 851.8 & 0.6 \\
\hline 6414 & 8 & 853.7 & 2.5 \\
\hline 6415 & 10 & 850.5 & -0.7 \\
\hline 6416 & 12 & 851.5 & 0.3 \\
\hline 6417 & 14 & 849.5 & -1.7 \\
\hline 6418 & 17 & 848.9 & -2.3 \\
\hline 6419 & 19 & 851.8 & 0.6 \\
\hline 6420 & 21 & 850.3 & -0.9 \\
\hline 6421 & 24 & 851.3 & 0.1 \\
\hline 6422 & 30 & 853.0 & 1.8 \\
\hline & & & \\
\hline \multicolumn{2}{|c|}{ MAD } & & 1.1 \\
\hline
\end{tabular}

\begin{tabular}{|c|c|}
\hline $1 \mathrm{~A}$ & 37.4 \\
\hline $1 \mathrm{C}$ & 36.2 \\
\hline $1 \mathrm{E}$ & 36.9 \\
\hline $30 \mathrm{~A}$ & 39.6 \\
\hline $30 \mathrm{C}$ & 38.1 \\
\hline $30 \mathrm{E}$ & 37.4 \\
\hline
\end{tabular}

Control Group

\begin{tabular}{l} 
Control Group \\
\begin{tabular}{|c|c|c|c|}
\hline 6403 & & & -0.6 \\
\hline 6404 & & & 0.8 \\
\hline 6405 & & & lost \\
\hline 6406 & & & 1.0 \\
\hline 6407 & & & -0.2 \\
\hline 6408 & & & 0.6 \\
\hline 6409 & & & -0.7 \\
\hline 6410 & & & 0.8 \\
\hline 6411 & & & -0.8 \\
\hline 6412 & & & -1.0 \\
\hline & & & \\
\hline
\end{tabular} \\
\hline
\end{tabular}

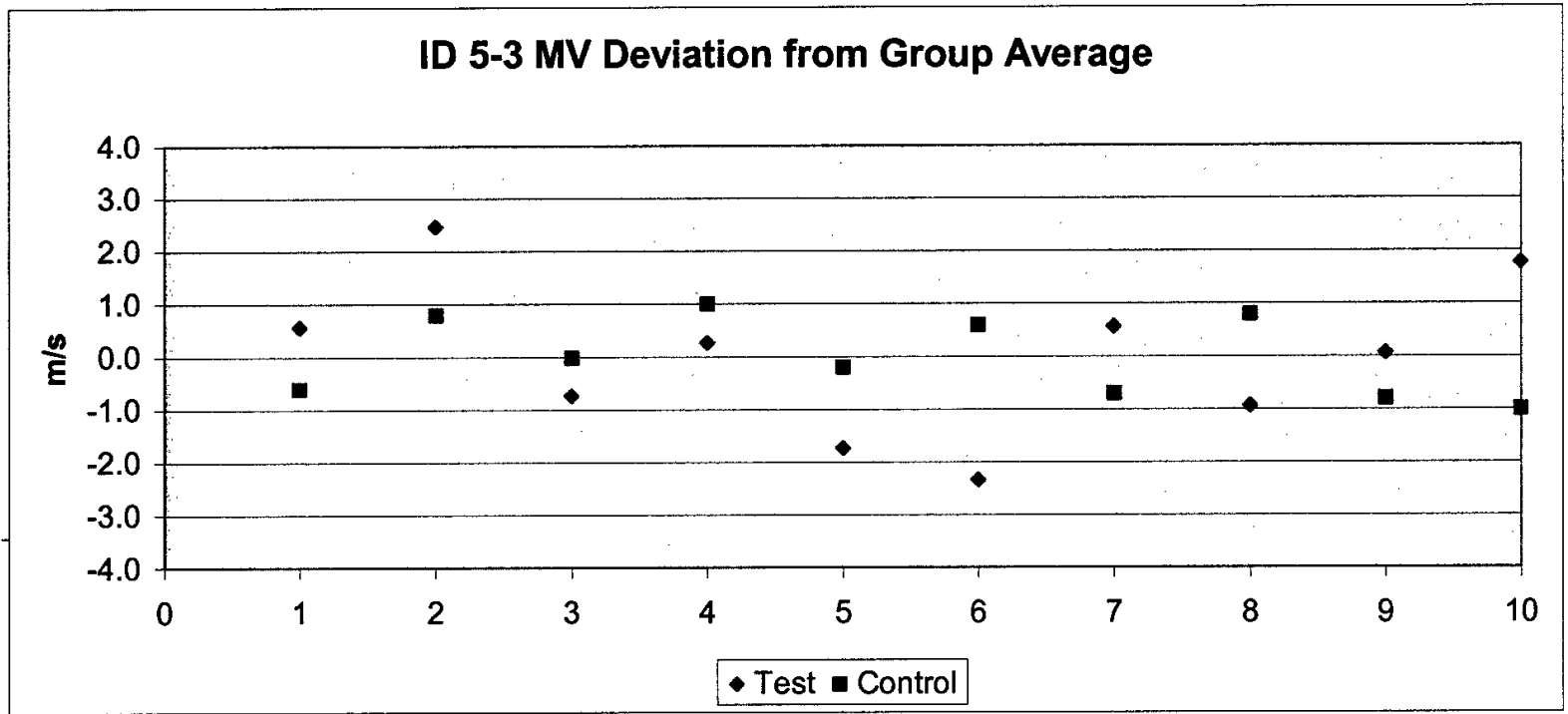


Zone 5 - Occasion 4
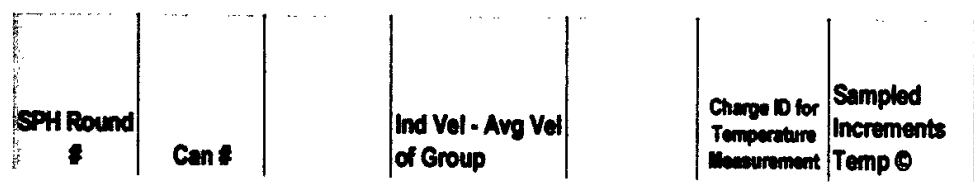

Test Group

\begin{tabular}{|c|c|c|c|}
\hline 6264 & 1 & 846.7 & 0.1 \\
\hline 6265 & 5 & 847.3 & 0.6 \\
\hline 6266 & 8 & 847.0 & 0.4 \\
\hline 6267 & 10 & 846.1 & -0.5 \\
\hline 6268 & 15 & 846.2 & -0.4 \\
\hline 6269 & 17 & 845.7 & -0.9 \\
\hline 6270 & 20 & 845.1 & -1.5 \\
\hline 6271 & 24 & 848.8 & 2.1 \\
\hline 6272 & 27 & 844.8 & -1.9 \\
\hline 6273 & 30 & 848.8 & 2.1 \\
\hline & & & \\
\hline \multicolumn{2}{|c|}{ MAD } & & 1.1 \\
\hline
\end{tabular}

\begin{tabular}{|c|c|}
\hline $1 A$ & 22.9 \\
\hline $1 C$ & 22.6 \\
\hline $1 E$ & 22.4 \\
\hline $27 C$ & 22.7 \\
\hline $30 A$ & 25.4 \\
\hline $30 C$ & 24.8 \\
\hline $30 E$ & 25.3 \\
\hline
\end{tabular}

Control Group

\begin{tabular}{|c|c|c|c|}
\hline 6274 & & & -1.4 \\
\hline 6275 & & & -1.7 \\
\hline 6276 & & & -0.3 \\
\hline 6277 & & & -1.4 \\
\hline 6278 & & & -2.4 \\
\hline 6279 & & & 1.2 \\
\hline 6280 & & & -3.0 \\
\hline 6281 & & & 4.1 \\
\hline 6282 & & & 1.5 \\
\hline 6283 & & & 3.0 \\
\hline & & & \\
\hline MAD & & 2.0 \\
\hline
\end{tabular}

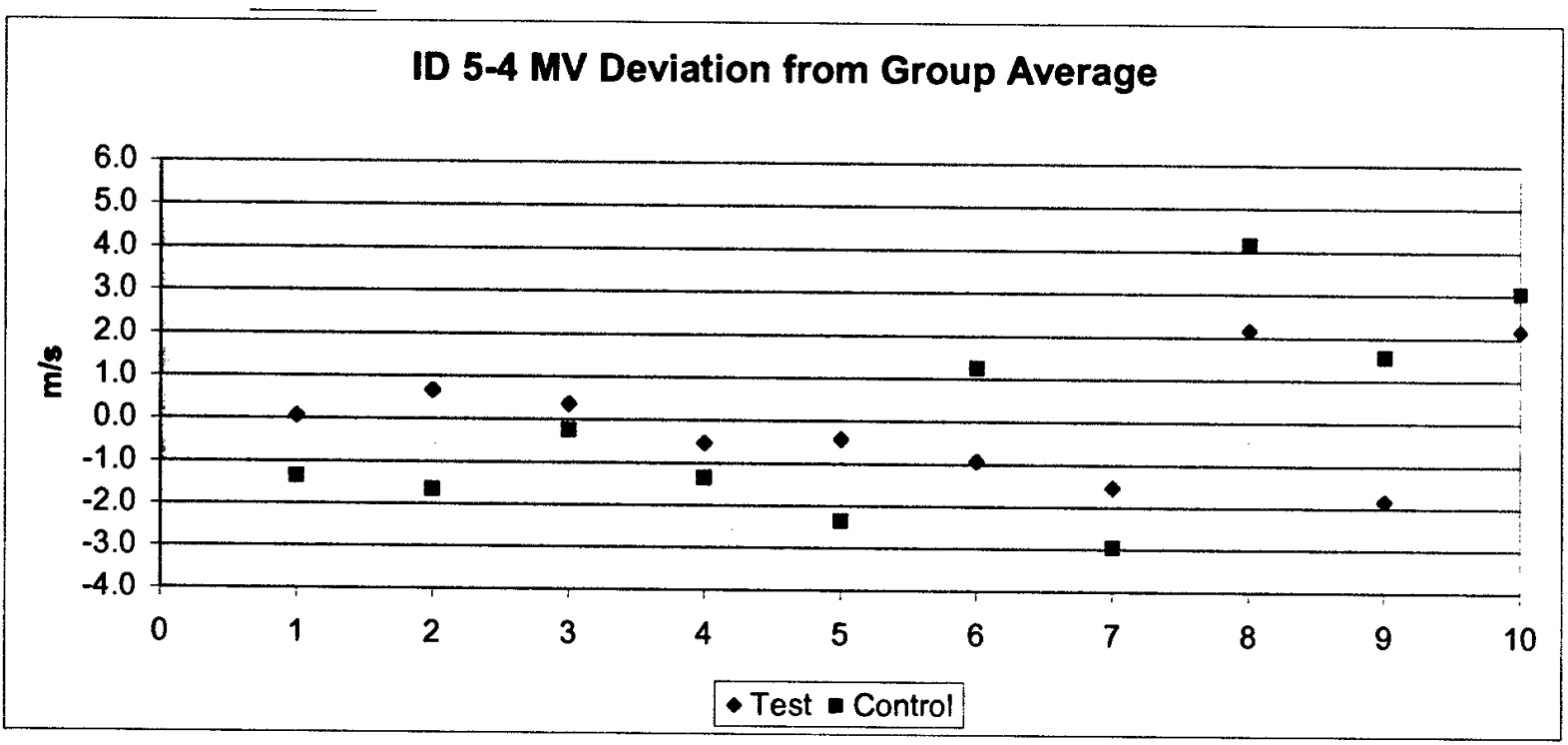


Zone 5 - Occasion 5

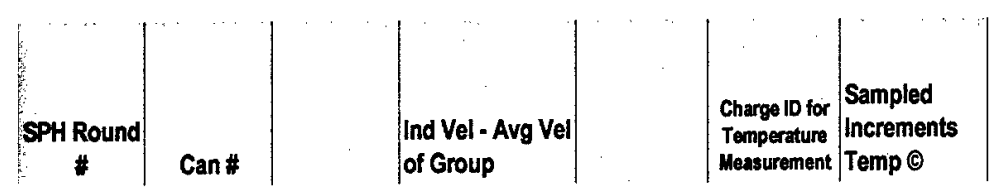

Test Group

\begin{tabular}{|c|c|c|c|}
\hline 6373 & 2 & 850.7 & 2.3 \\
\hline 6374 & 6 & 847.8 & -0.7 \\
\hline 6375 & 7 & 847.6 & -0.9 \\
\hline 6376 & 11 & 845.9 & -2.6 \\
\hline 6377 & 14 & 847.9 & -0.6 \\
\hline 6378 & 18 & 849.0 & 0.5 \\
\hline 6379 & 20 & 845.4 & -3.1 \\
\hline 6380 & 22 & 850.5 & 2.0 \\
\hline 6381 & 25 & 850.2 & 1.8 \\
\hline 6382 & 29 & 849.5 & 1.0 \\
\hline & & & \\
\hline \multicolumn{2}{|c|}{ MAD } & & 1.5 \\
\hline
\end{tabular}

\begin{tabular}{|c|c|}
\hline $6 \mathrm{~A}$ & 34.2 \\
\hline $6 \mathrm{C}$ & 32.7 \\
\hline $6 \mathrm{E}$ & 32.1 \\
\hline $25 \mathrm{~A}$ & 35.1 \\
\hline $25 \mathrm{C}$ & 30.7 \\
\hline $25 \mathrm{E}$ & 30.5 \\
\hline
\end{tabular}

Control Group

\begin{tabular}{|c|c|c|c|}
\hline 6363 & & & -1.3 \\
\hline 6364 & & & -0.1 \\
\hline 6365 & & & 0.3 \\
\hline 6366 & & & -0.1 \\
\hline 6367 & & & lost \\
\hline 6368 & & & 0.3 \\
\hline 6369 & & & 0.4 \\
\hline 6370 & & & 0.9 \\
\hline 6371 & & & -0.4 \\
\hline 6372 & & & \\
\hline & & & 0.4 \\
\hline \multicolumn{2}{|c|}{ MAD } & & \\
\hline
\end{tabular}

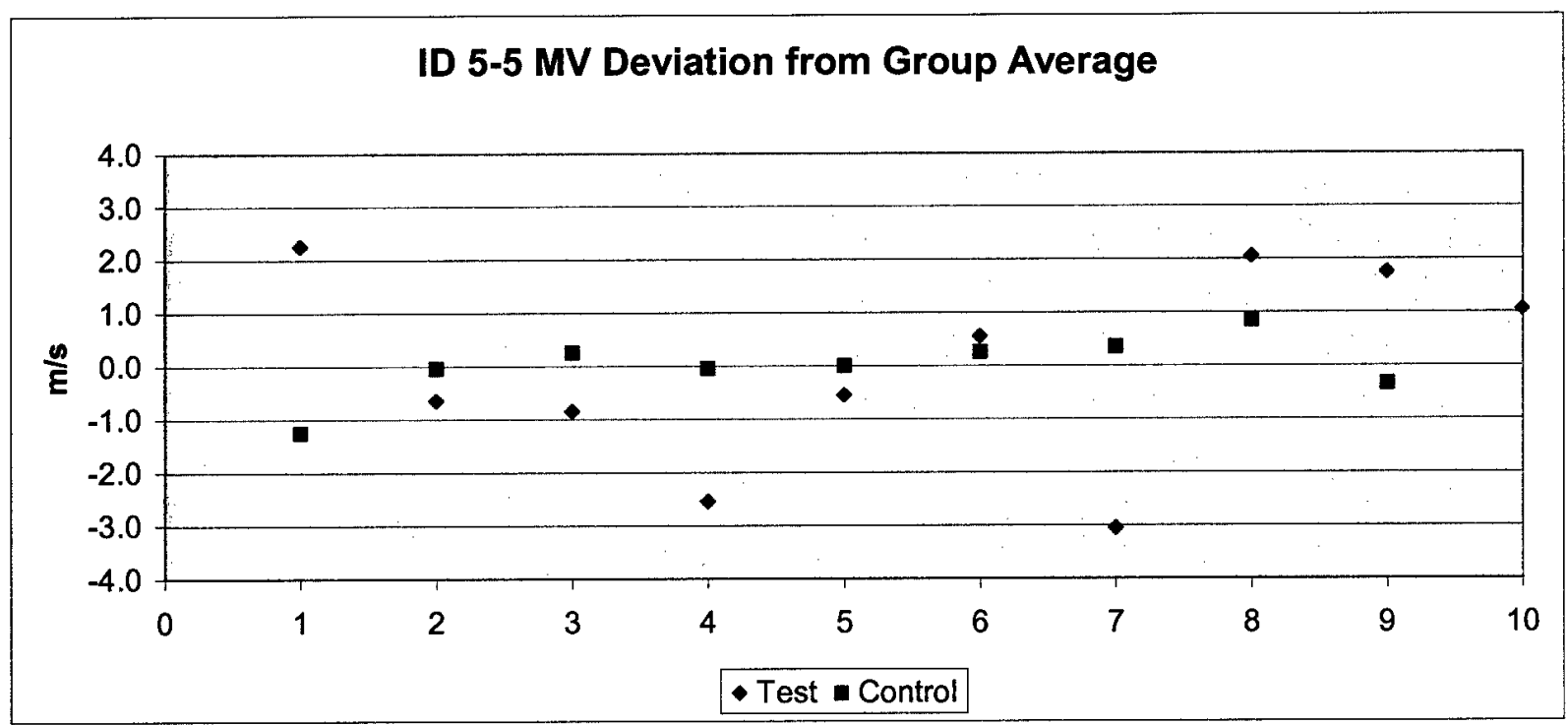


Zone 6 - Occasion 1

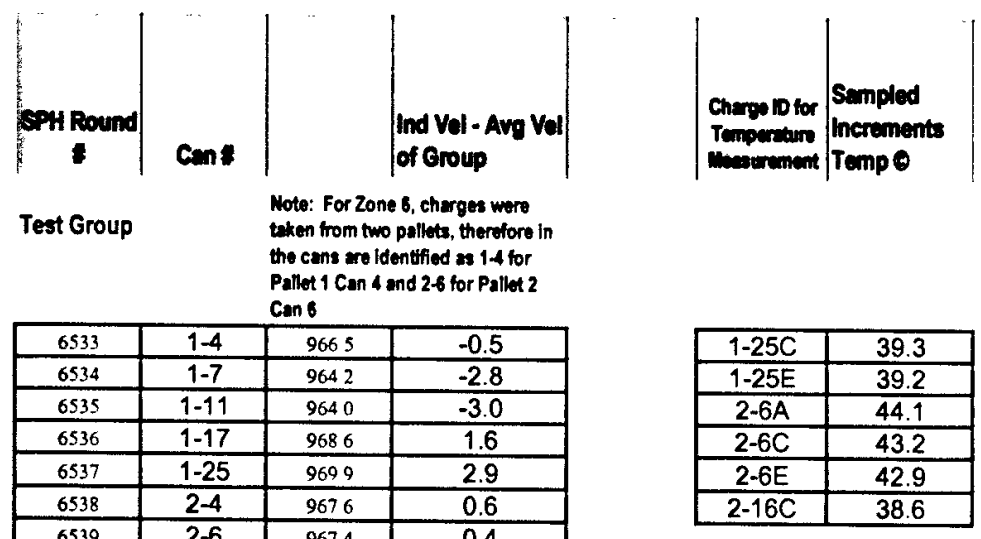

\begin{tabular}{|c|c|c|c|}
\hline 6539 & $2-6$ & 9674 & 0.4 \\
\hline 6540 & $2-11$ & 9676 & 0.6 \\
\hline 6541 & $2-16$ & 9681 & 1.1 \\
\hline 6542 & $2-20$ & 9662 & -0.8 \\
\hline & & & \\
\hline \multicolumn{2}{|c|}{ MAD } & & 1.4 \\
\hline
\end{tabular}

Control Group

\begin{tabular}{|c|c|c|c|}
\hline 6523 & & & -2.1 \\
\hline 6524 & & & 2.5 \\
\hline 6525 & & & -0.2 \\
\hline 6526 & & & 1.9 \\
\hline 6527 & & & -0.2 \\
\hline 6528 & & & -0.8 \\
\hline 6529 & & & 1.5 \\
\hline 6530 & & & 1.1 \\
\hline 6531 & & & -1.6 \\
\hline 6532 & & & -1.5 \\
\hline & & & \\
\hline \multicolumn{2}{|c|}{ MAD } & & 1.3 \\
\hline
\end{tabular}

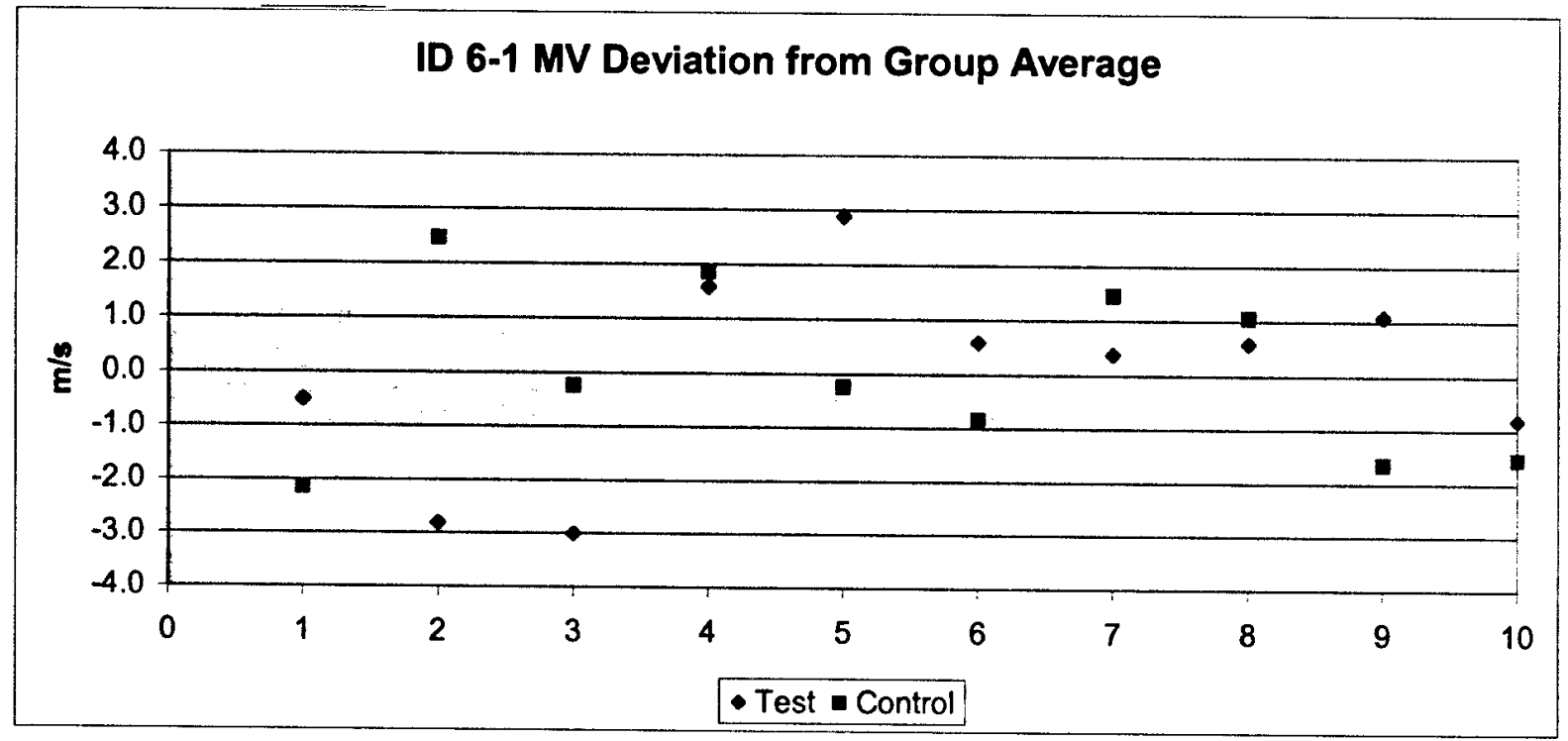


Zone 6 - Occasion 2

\begin{tabular}{|c|c|c|c|}
\hline $\begin{array}{c}\text { SPH Round } \\
\sharp\end{array}$ & Can & & $\begin{array}{l}\text { Ind Vel - Avg Vel } \\
\text { of Group }\end{array}$ \\
\hline \multicolumn{2}{|l|}{ Test Group } & \multicolumn{2}{|c|}{$\begin{array}{l}\text { Note: For Zone } 6 \text {, charges were } \\
\text { taken from two pallets, therefore in } \\
\text { the cans are identified as } 1.2 \text { for } \\
\text { Pallet } 1 \text { Can } 2 \text { and } 2.6 \text { for Pallet } 2 \\
\text { Can } 6\end{array}$} \\
\hline 6433 & $1-2$ & 963.1 & -1.6 \\
\hline 6434 & 1.7 & 963.2 & -1.5 \\
\hline 6435 & $1-11$ & 962.6 & -2.1 \\
\hline 6436 & $1-16$ & 963.9 & -0.8 \\
\hline 6437 & $1-20$ & 964.5 & -0.2 \\
\hline 6438 & $1-22$ & 967.5 & 2.8 \\
\hline 6439 & $2-6$ & 966.7 & 2.0 \\
\hline 6440 & $2-11$ & 965.5 & 0.8 \\
\hline 6441 & $2-14$ & 965.3 & 0.6 \\
\hline 6442 & $2-18$ & 965.0 & 0.3 \\
\hline MA & & & 1.3 \\
\hline
\end{tabular}

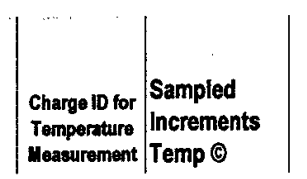

Control Group
\begin{tabular}{|c|c|c|c|}
\hline 6423 & & 966.6 & -1.9 \\
\hline 6424 & & 963.9 & -1.1 \\
\hline 6425 & & 964.4 & 1.5 \\
\hline 6426 & & 963.7 & 0.9 \\
\hline 6427 & & 965.8 & 0.5 \\
\hline 6428 & & 965.1 & -0.6 \\
\hline 6429 & & 965.0 & 0.8 \\
\hline 6430 & & 964.4 & 1.4 \\
\hline 6431 & & 964.2 & -0.6 \\
\hline 6432 & & 965.5 & -0.7 \\
\hline & & & \\
\hline \multicolumn{2}{|c|}{ MAD } & & 1.0 \\
\hline
\end{tabular}

\begin{tabular}{|l|l|}
\hline $1-16 C$ & 31.4 \\
\hline $2-6 A$ & 36.4 \\
\hline $2-6 C$ & 35.9 \\
\hline $2-6 E$ & 35.2 \\
\hline
\end{tabular}

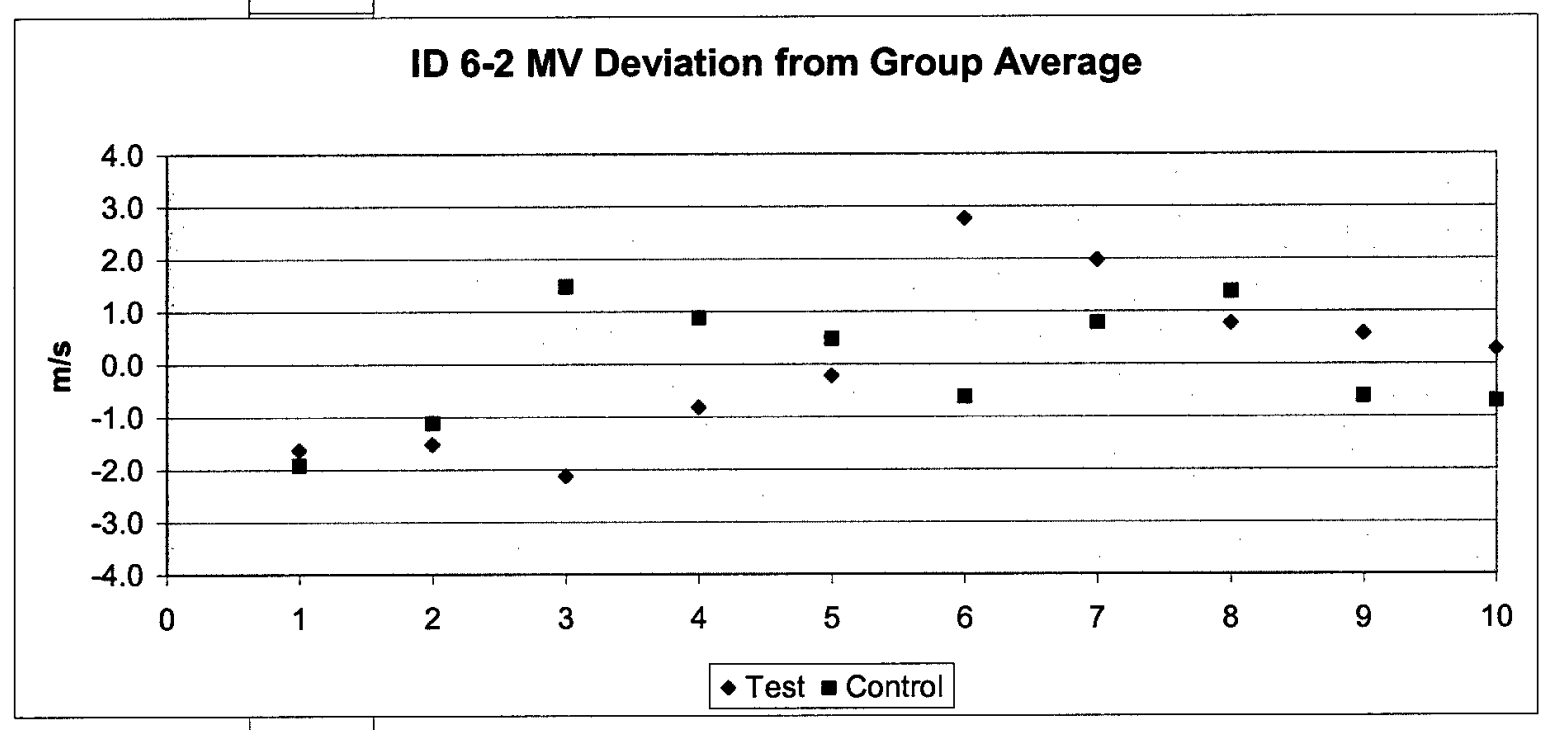


Zone 6 - Occasion 3
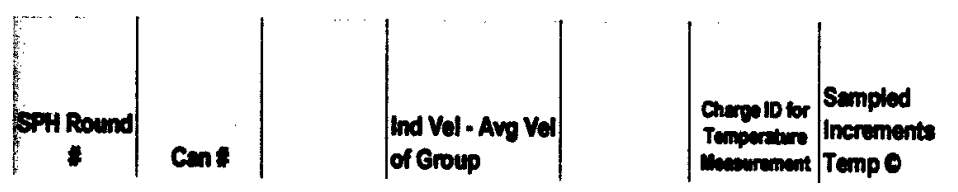

Test Group

\begin{tabular}{|c|c|c|c|}
\hline & & \multicolumn{2}{|c|}{$\begin{array}{l}\text { No Control group data due to long } \\
\text { broak between rounds in the group }\end{array}$} \\
\hline 6393 & $1-3$ & 9666 & 1.7 \\
\hline 6394 & $1-7$ & 9639 & -1.0 \\
\hline 6395 & $1-9$ & 9644 & -0.5 \\
\hline 6396 & $1-12$ & 9637 & -1.2 \\
\hline 6397 & $1-13$ & 9658 & 0.9 \\
\hline 6398 & $1-16$ & 9651 & 0.2 \\
\hline 6399 & $1-19$ & 9650 & 0.1 \\
\hline 6400 & $1-23$ & 9644 & -0.5 \\
\hline 6401 & $1-26$ & 9642 & -0.7 \\
\hline 6402 & $1-29$ & 9655 & 0.6 \\
\hline
\end{tabular}

1-16C

\begin{tabular}{|l|l|l|}
\hline MAD & & 0.7 \\
\hline
\end{tabular}

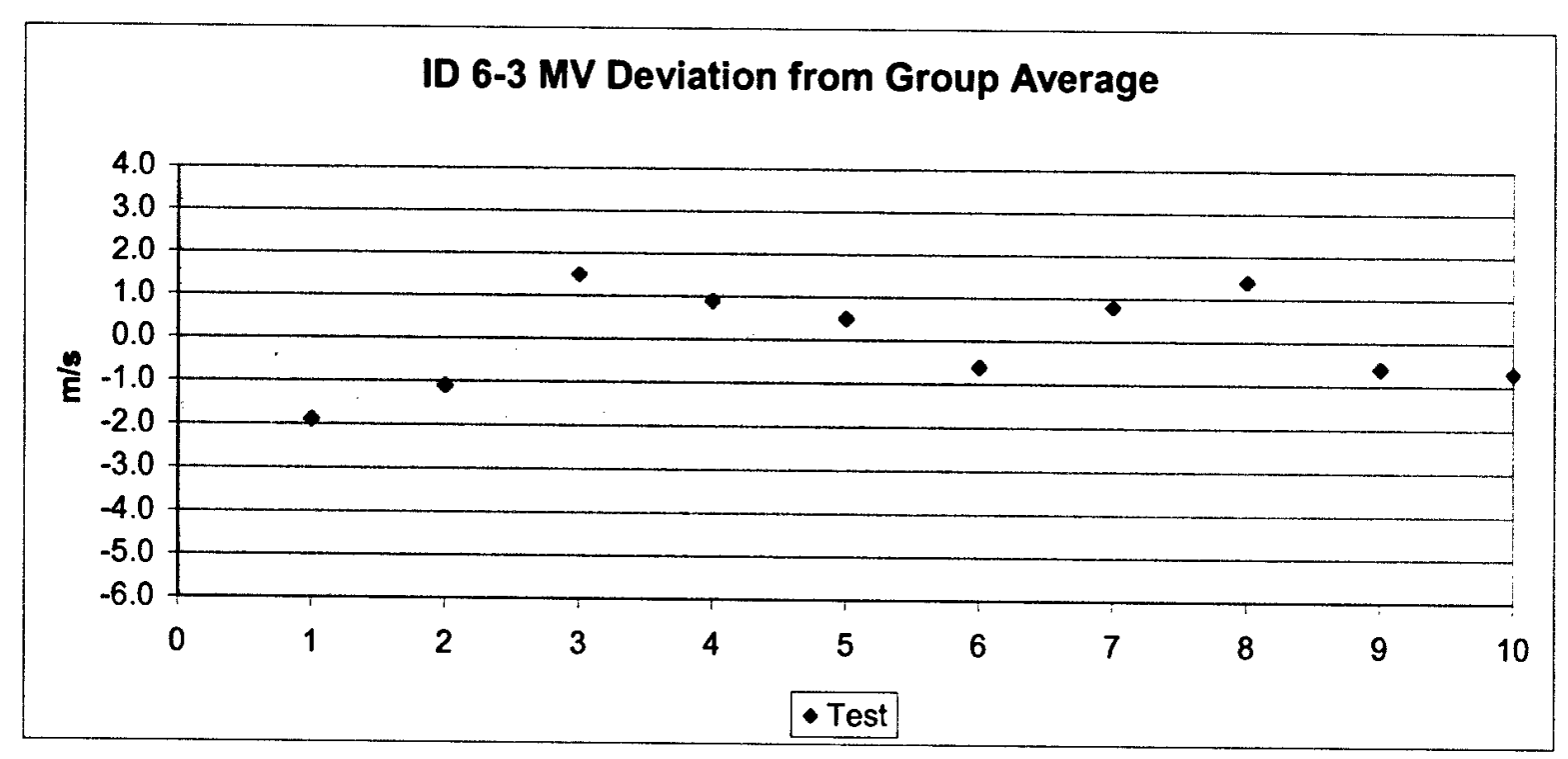


Zone 6 - Occasion 4

\begin{tabular}{|c|c|c|c|}
\hline $\begin{array}{c}\text { SPH Round } \\
\vdots\end{array}$ & Can\# & & $\begin{array}{l}\text { Ind Vel - Avg Vel } \\
\text { of Group }\end{array}$ \\
\hline \multicolumn{2}{|l|}{ Test Group } & \multicolumn{2}{|c|}{$\begin{array}{l}\text { Note: For Zone } 6 \text {, charges were } \\
\text { taken from two pallets, therefore in } \\
\text { the cans are identified as } 1-4 \text { for } \\
\text { Pallet } 1 \text { Can } 4 \text { and } 2-8 \text { for Pallet } 2 \\
\text { Can } 8\end{array}$} \\
\hline 6244 & $1-4$ & 954.6 & -1.8 \\
\hline 6245 & $1-25$ & 954.0 & -2.4 \\
\hline 6246 & $2-1$ & 955.8 & -0.6 \\
\hline 6247 & $2-4$ & 956.6 & 0.2 \\
\hline 6248 & $2-8$ & 957.7 & 1.3 \\
\hline 6249 & $2-13$ & 956.5 & 0.1 \\
\hline 6250 & $2-16$ & 957.5 & 1.1 \\
\hline 6251 & $2-19$ & 956.0 & -0.4 \\
\hline 6252 & $2-23$ & 957.8 & 1.4 \\
\hline 6253 & $2-26$ & 957.9 & 1.5 \\
\hline & $2-28$ & & \\
\hline $\mathrm{M} /$ & & & 1.1 \\
\hline
\end{tabular}

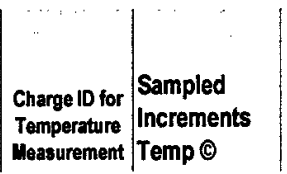

Control Group

\begin{tabular}{|c|c|c|c|}
\hline 6254 & & & -1.7 \\
\hline 6255 & & & -0.9 \\
\hline 6256 & & & 0.4 \\
\hline 6257 & & & 1.4 \\
\hline 6258 & & & 0.6 \\
\hline 6259 & & & 1.1 \\
\hline 6260 & & & -0.5 \\
\hline 6261 & & & 0.3 \\
\hline 6262 & & & -0.9 \\
\hline 6263 & & & 0.5 \\
\hline & & & 0.8 \\
\hline \multicolumn{2}{|c|}{ MAD } & & \\
\hline
\end{tabular}

\begin{tabular}{|l|l|}
\hline $1-25 \mathrm{~A}$ & 20.9 \\
\hline $1-25 \mathrm{C}$ & 21.4 \\
\hline $1-25 \mathrm{E}$ & 21.3 \\
\hline $2-1 \mathrm{~A}$ & 21.6 \\
\hline $2-1 \mathrm{C}$ & 21.6 \\
\hline $2-1 \mathrm{E}$ & 21.2 \\
\hline $2-16 \mathrm{C}$ & 23.0 \\
\hline
\end{tabular}

\section{ID 6-4 MV Deviation from Group Average}

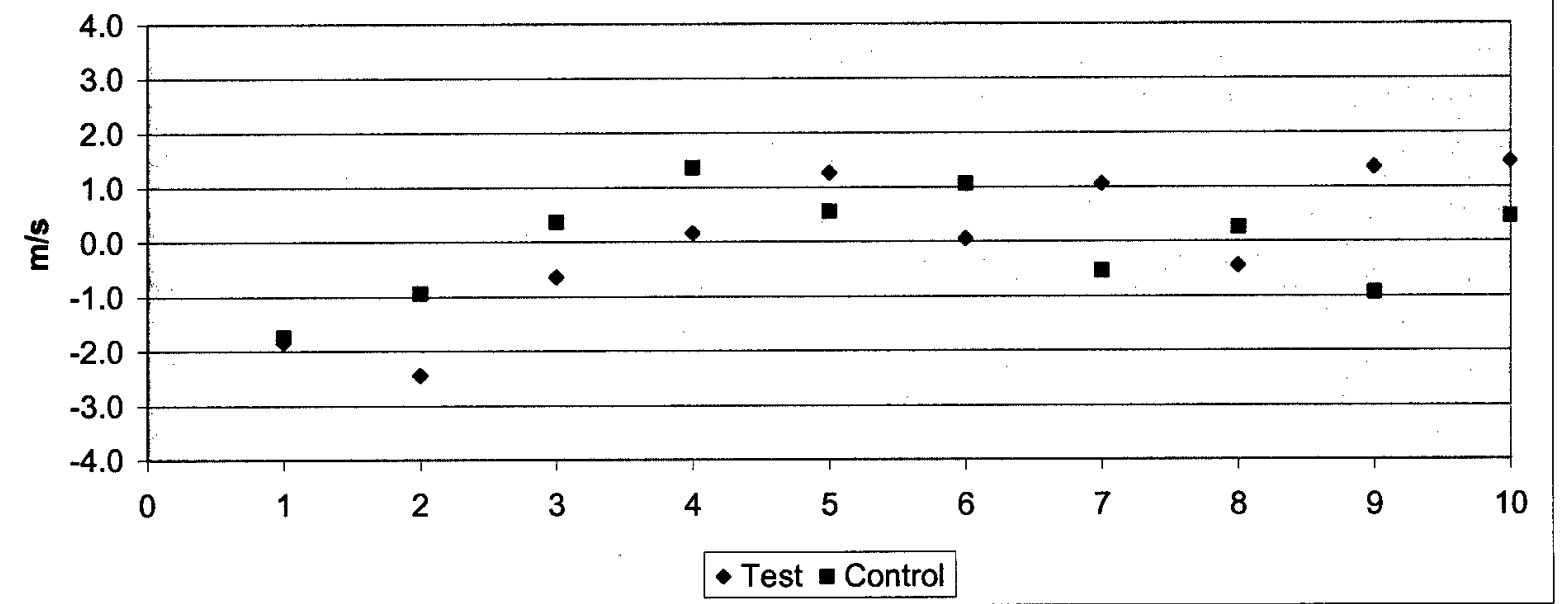


Zone 6 - Occasion 5
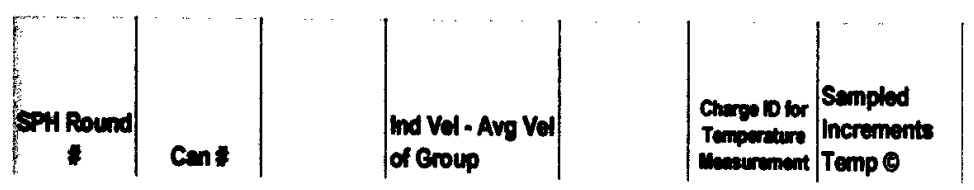

Test Group

\begin{tabular}{|c|c|c|c|}
\hline 6355 & $1-3$ & 9607 & -0.4 \\
\hline 6356 & $1-5$ & 9581 & -3.0 \\
\hline 6357 & $1-9$ & 9611 & 0.0 \\
\hline 6358 & $1-12$ & 9605 & -0.6 \\
\hline 6359 & $1-15$ & 9621 & 1.0 \\
\hline 6360 & $1-17$ & 9617 & 0.6 \\
\hline 6361 & $1-21$ & 9640 & 2.9 \\
\hline 6362 & $1-24$ & 9604 & -0.7 \\
\hline & $1-27$ & & \\
\hline & $1-30$ & & \\
\hline & & & 1.2 \\
\hline
\end{tabular}

\begin{tabular}{|l|l|}
\hline $1-27 \mathrm{C}$ & 23.2 \\
\hline $1-30 \mathrm{~A}$ & 28.9 \\
\hline $1-30 \mathrm{C}$ & 27.7 \\
\hline $1-30 \mathrm{E}$ & 28.8 \\
\hline
\end{tabular}

Control Group
\begin{tabular}{|c|c|c|c|}
\hline 6347 & & & 1.3 \\
\hline 6348 & & & -0.3 \\
\hline 6349 & & & -1.7 \\
\hline 6350 & & & 0.3 \\
\hline 6351 & & & 1.0 \\
\hline 6352 & & & -1.8 \\
\hline 6353 & & & -0.3 \\
\hline 6354 & & & 1.4 \\
\hline & & & \\
\hline MAD & & 0.8 \\
\hline
\end{tabular}

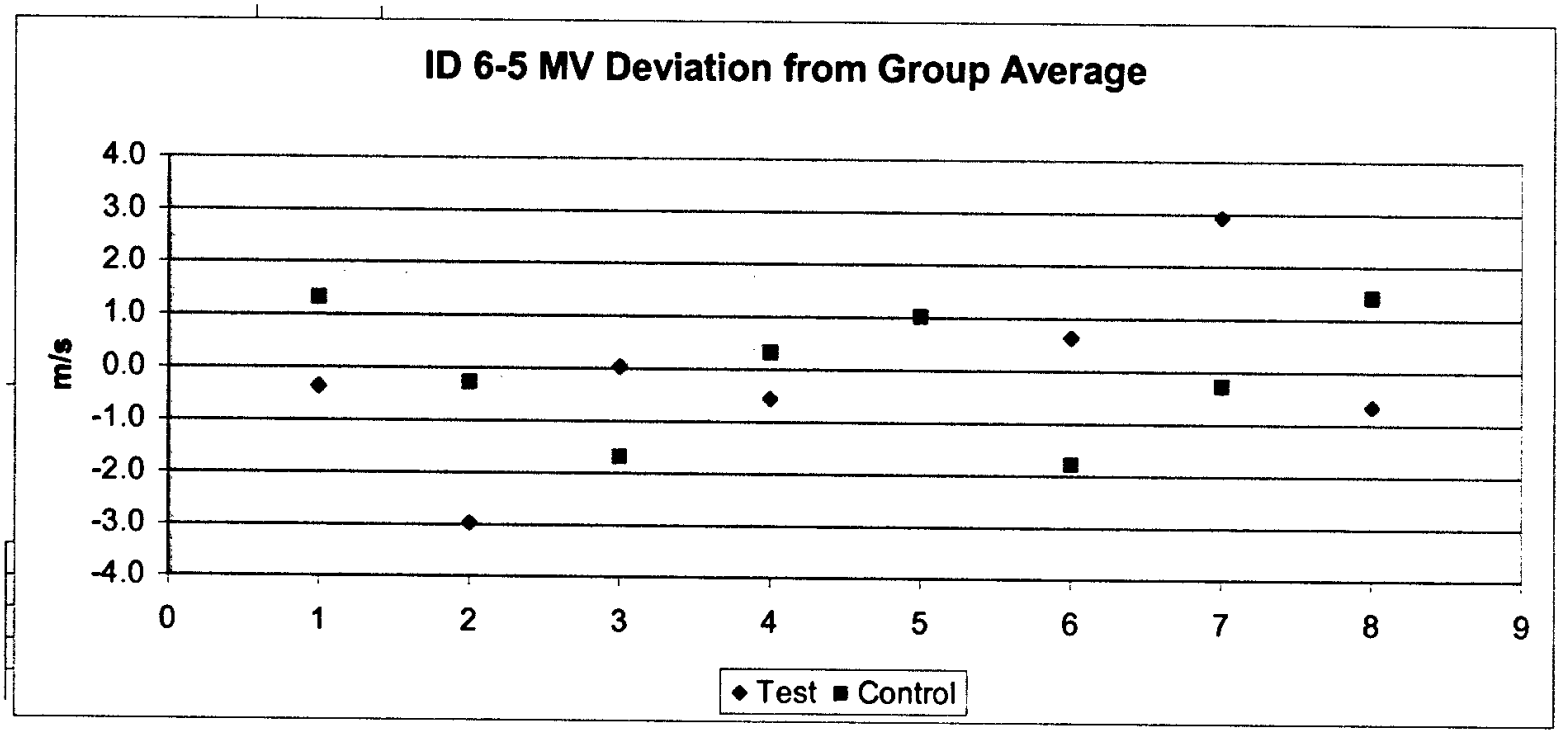




\section{Phase 2}

\begin{tabular}{|c|c|c|}
\hline $\begin{array}{c}\text { Zone 6 } \\
\text { Mission } \\
\text { ID }\end{array}$ & $\begin{array}{c}\text { Sampled } \\
\text { Increments } \\
\text { Temp @ }\end{array}$ & $\begin{array}{c}\text { Velocity } \\
\text { Measured - } \\
\text { Average } \\
\text { Velocity of } \\
\text { Group }\end{array}$ \\
\hline $1-1$ & 30.9 & -2.1 \\
\hline & 30.7 & -0.5 \\
\hline & 31.7 & -2.2 \\
\hline & 31.9 & -1.0 \\
\hline & 32.6 & 1.6 \\
\hline & 32.5 & 0.5 \\
\hline & 33.4 & 1.0 \\
\hline & 32.9 & -1.2 \\
\hline & 32.6 & -0.4 \\
\hline & 32.3 & 0.7 \\
\hline & & -0.9 \\
\hline & & 1.6 \\
\hline & & 2.5 \\
\hline & & 0.4 \\
\hline & & 0.7 \\
\hline
\end{tabular}

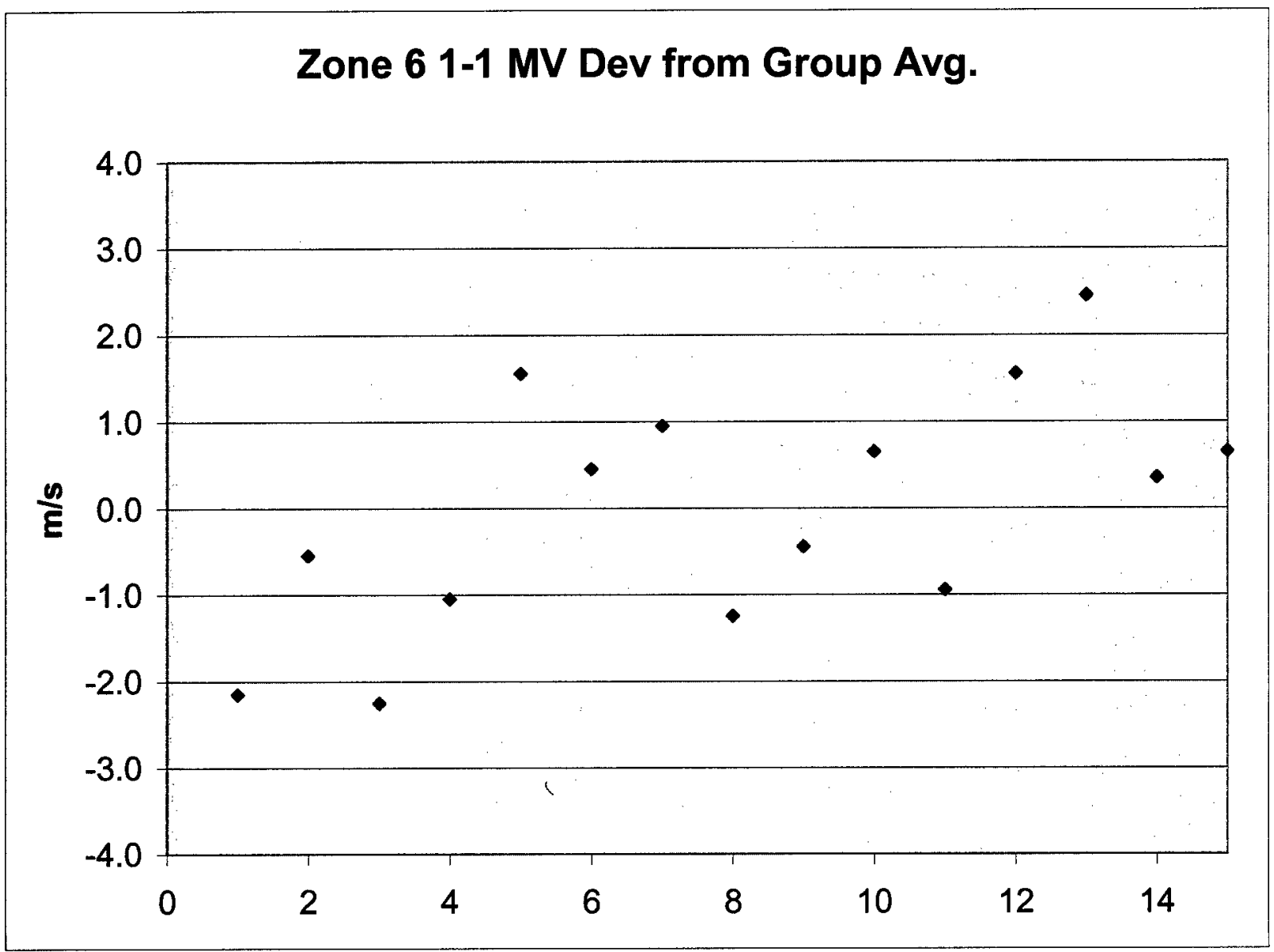




\begin{tabular}{|c|c|c|}
\hline Zone e & $\begin{array}{c}\text { Volocity } \\
\text { ineasured - } \\
\text { Average } \\
\text { Den }\end{array}$ & $\begin{array}{c}\text { Averements } \\
\text { Velocity of } \\
\text { Group }\end{array}$ \\
\hline $1-2$ & 34.3 & 0.9 \\
\hline & 33.3 & -0.5 \\
\hline & 35.2 & -0.4 \\
\hline & 34.9 & 1.1 \\
\hline & 34.4 & 1.8 \\
\hline & 33.9 & -0.7 \\
\hline & 33.7 & -0.7 \\
\hline & 33.9 & -0.8 \\
\hline & 34.4 & 0.4 \\
\hline & 33.9 & 0.3 \\
\hline & & -0.9 \\
\hline & & -1.3 \\
\hline & & 0.4 \\
\hline & & -0.4 \\
\hline & & 1.3 \\
\hline
\end{tabular}

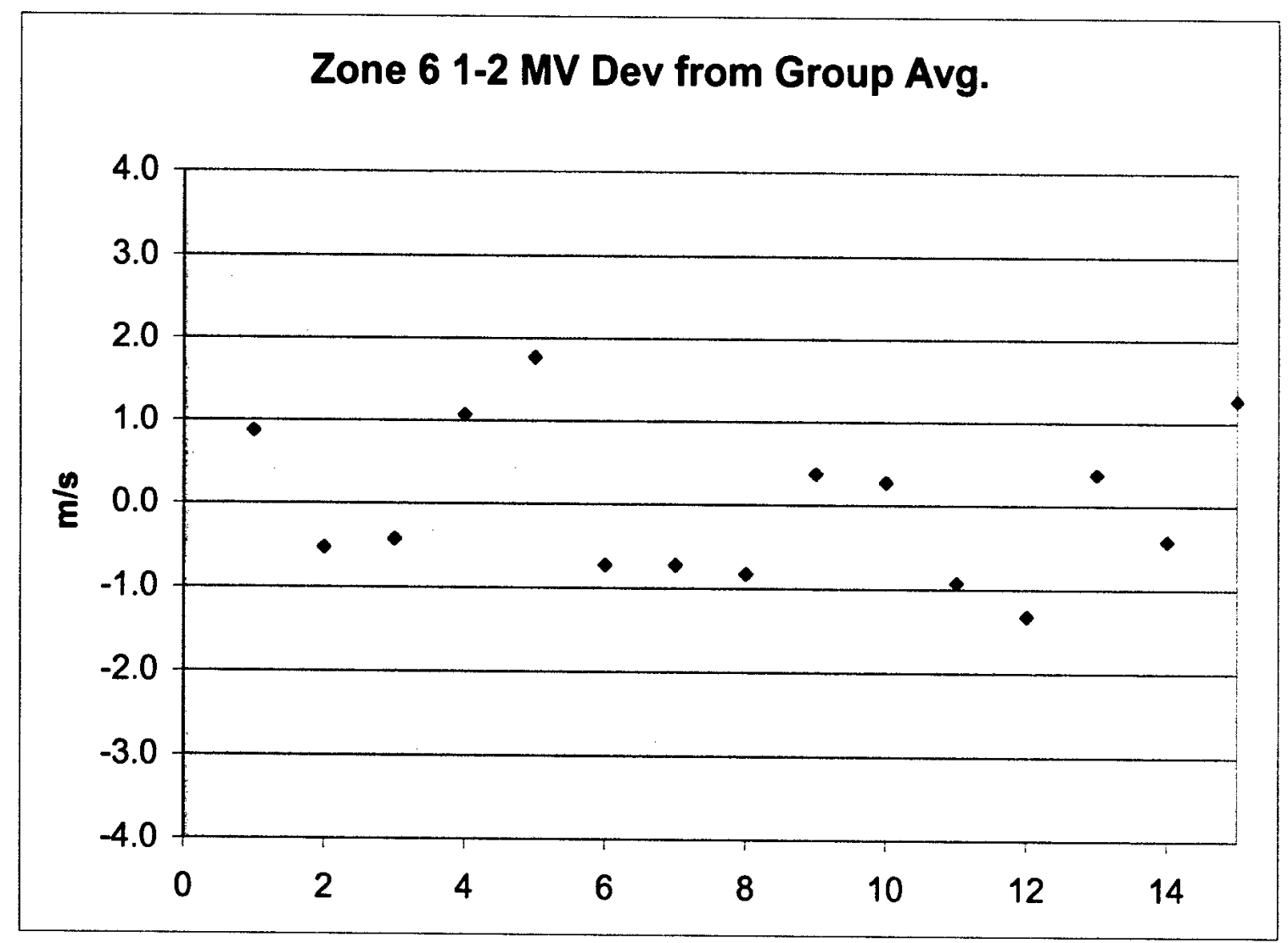




\begin{tabular}{|c|c|c|}
\hline $\begin{array}{c}\text { Zone 6 } \\
\text { Mission } \\
\text { ID }\end{array}$ & $\begin{array}{c}\text { Sampled } \\
\text { Increments } \\
\text { Temp @ }\end{array}$ & $\begin{array}{c}\text { Velocity } \\
\text { Measured - } \\
\text { Average } \\
\text { Velocity of } \\
\text { Group }\end{array}$ \\
\hline $1-2$ & 34.3 & 0.9 \\
\hline & 33.3 & -0.5 \\
\hline & 35.2 & -0.4 \\
\hline & 34.9 & 1.1 \\
\hline & 34.4 & 1.8 \\
\hline & 33.9 & -0.7 \\
\hline & 33.7 & -0.7 \\
\hline & 33.9 & -0.8 \\
\hline & 34.4 & 0.4 \\
\hline & 33.9 & 0.3 \\
\hline & & -0.9 \\
\hline & & -1.3 \\
\hline & & 0.4 \\
\hline & & -0.4 \\
\hline & & 1.3 \\
\hline
\end{tabular}

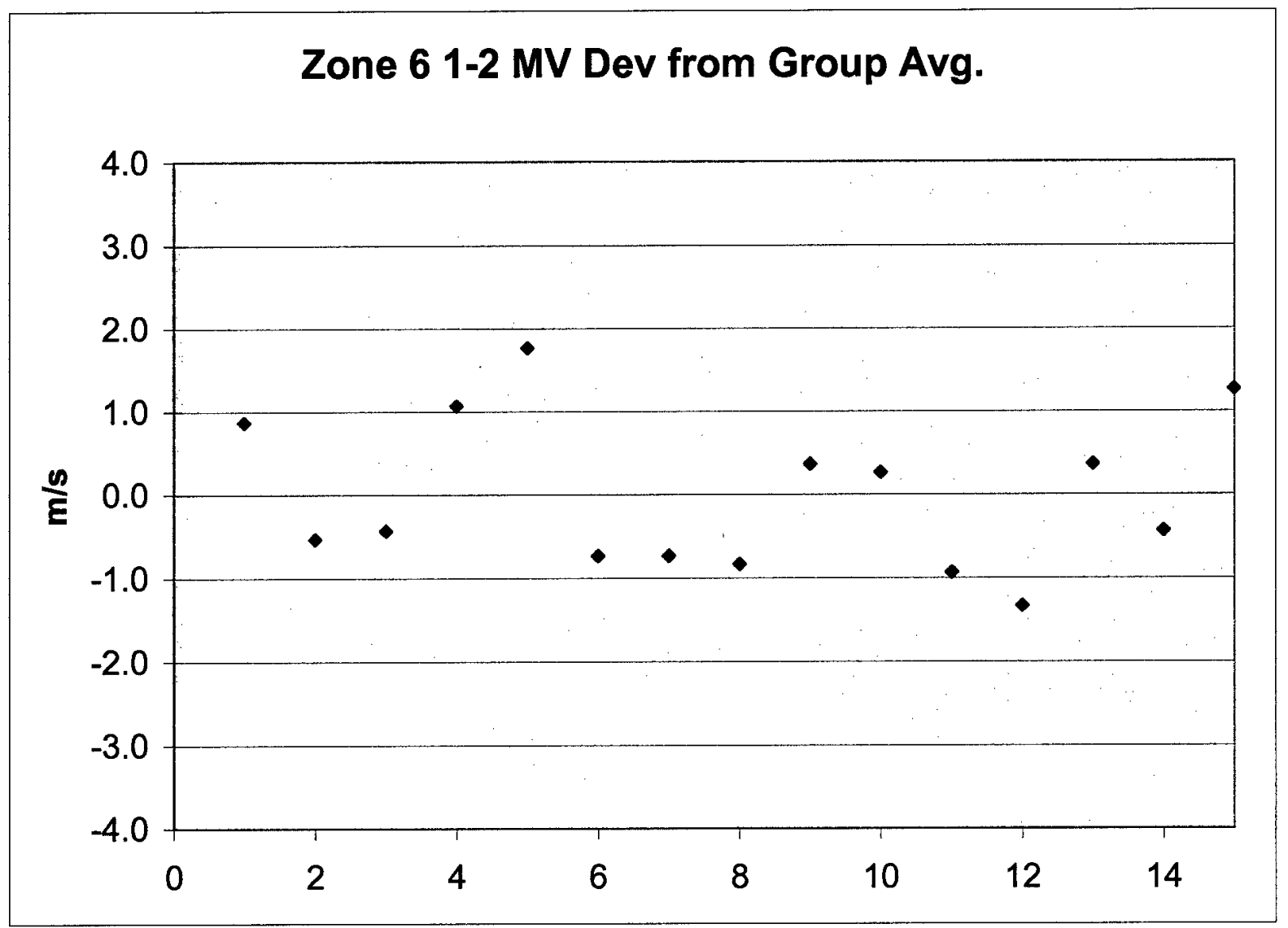




\begin{tabular}{|c|c|c|}
\hline zone e & $\begin{array}{c}\text { Senpled } \\
\text { meise }\end{array}$ & $\begin{array}{c}\text { Velocity } \\
\text { Measured - } \\
\text { Average } \\
\text { Velocity of } \\
\text { Group }\end{array}$ \\
\hline $1-3$ & 40.8 & 1.8 \\
\hline & 41.0 & 2.9 \\
\hline & 41.4 & 1.4 \\
\hline & 40.3 & 1.4 \\
\hline & 38.3 & 0.9 \\
\hline & 39.1 & -0.5 \\
\hline & 39.4 & 0.2 \\
\hline & 39.2 & 0.8 \\
\hline & 40.9 & -2.1 \\
\hline & 40.4 & -0.8 \\
\hline & & 1.4 \\
\hline & & 0.7 \\
\hline & & 1.0 \\
\hline & & -9.4 \\
\hline & & 0.2 \\
\hline
\end{tabular}

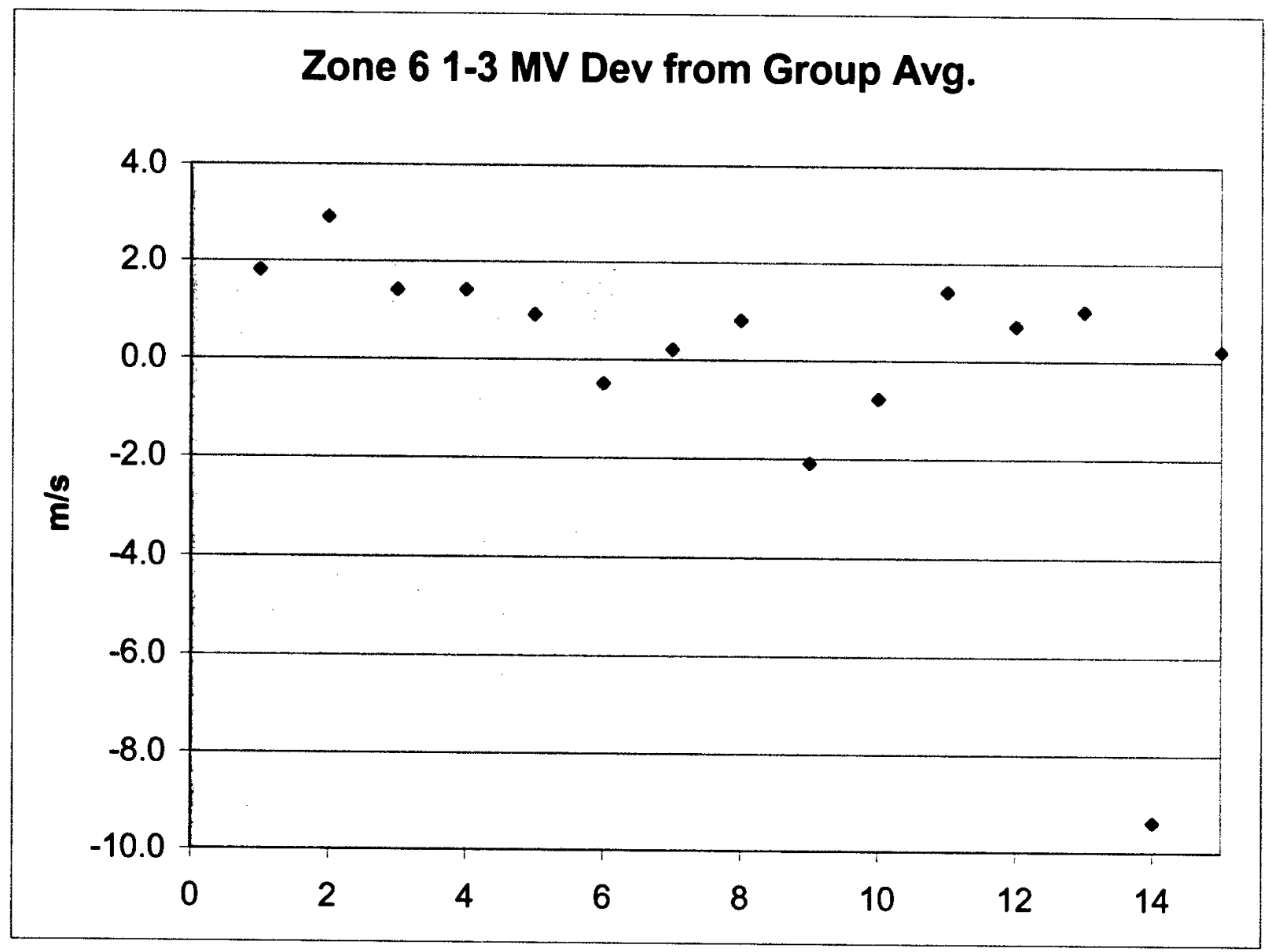




\begin{tabular}{|c|c|c|}
\hline $\begin{array}{c}\text { Zone 6 } \\
\text { Mission } \\
\text { ID }\end{array}$ & $\begin{array}{c}\text { Sampled } \\
\text { Increments } \\
\text { Temp C) }\end{array}$ & $\begin{array}{c}\text { Velocity } \\
\text { Measured - } \\
\text { Average } \\
\text { Velocity of } \\
\text { Group }\end{array}$ \\
\hline $1-4$ & 45.0 & 1.6 \\
\hline & 43.4 & 1.9 \\
\hline & 45.0 & 1.8 \\
\hline & 44.5 & -1.5 \\
\hline & 39.5 & -2.0 \\
\hline & 40.2 & 0.1 \\
\hline & 39.6 & -0.3 \\
\hline & 42.3 & -0.4 \\
\hline & 41.7 & 0.1 \\
\hline & 42.1 & -0.1 \\
\hline & & 2.9 \\
\hline & & 0.0 \\
\hline & & -1.3 \\
\hline & & -1.8 \\
\hline & & -1.6 \\
\hline
\end{tabular}

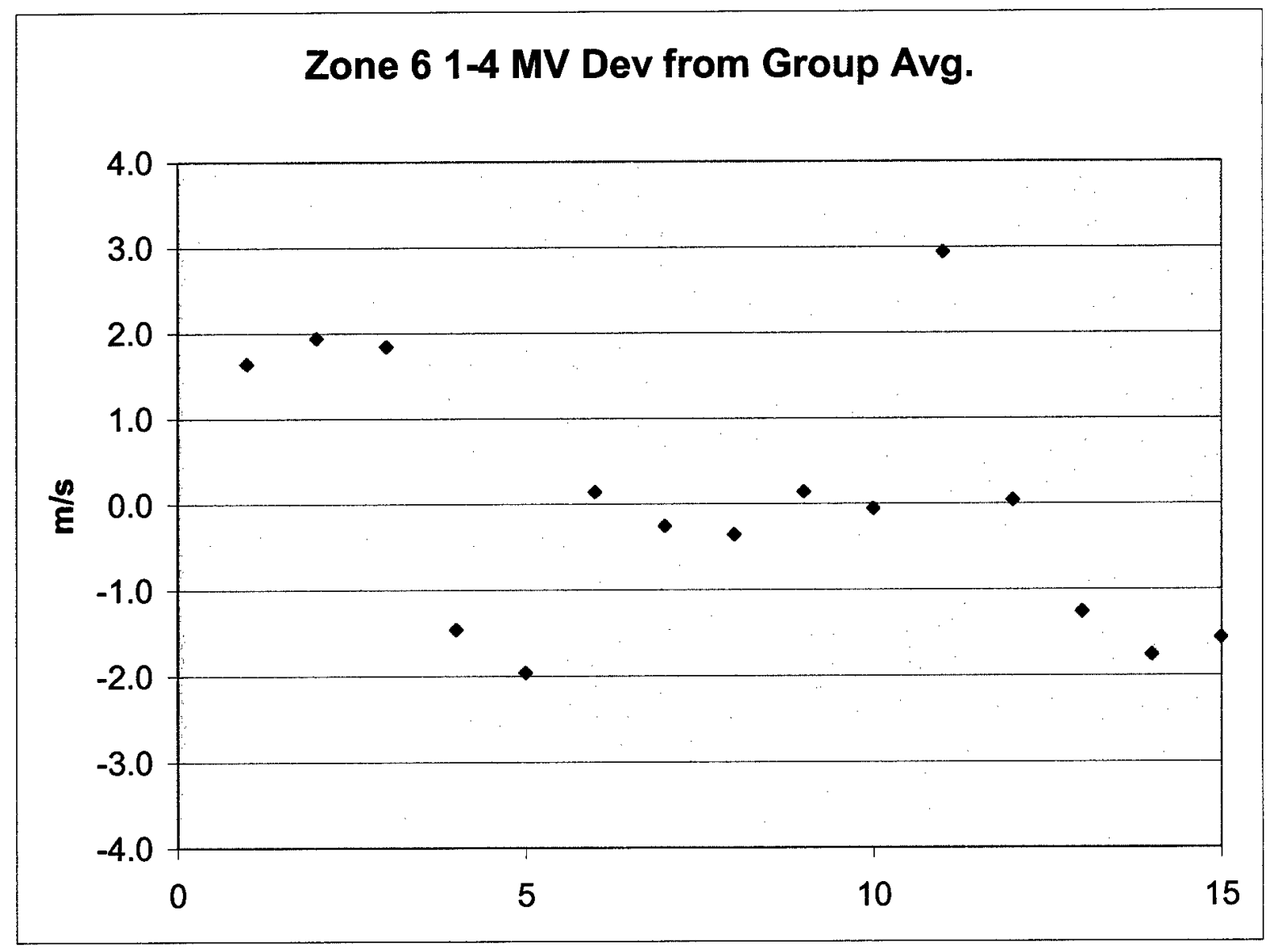




\begin{tabular}{|c|c|c|}
\hline & Zoocity \\
\hline$D$ & $\begin{array}{c}\text { Vemplud } \\
\text { Measured - } \\
\text { Average } \\
\text { Velocity of } \\
\text { Group }\end{array}$ \\
\hline $2-1$ & 29.7 & -3.9 \\
\hline & 29.7 & 1.2 \\
\hline & 29.9 & -0.6 \\
\hline & 29.6 & -1.6 \\
\hline & 30.6 & 1.4 \\
\hline & 30.4 & -0.8 \\
\hline & 30.8 & 0.4 \\
\hline & 30.1 & 0.1 \\
\hline & 30.8 & -2.1 \\
\hline & 30.4 & -0.6 \\
\hline & & 0.0 \\
\hline & & 1.7 \\
\hline & & 0.9 \\
\hline & & 2.8 \\
\hline & & 1.8 \\
\hline
\end{tabular}

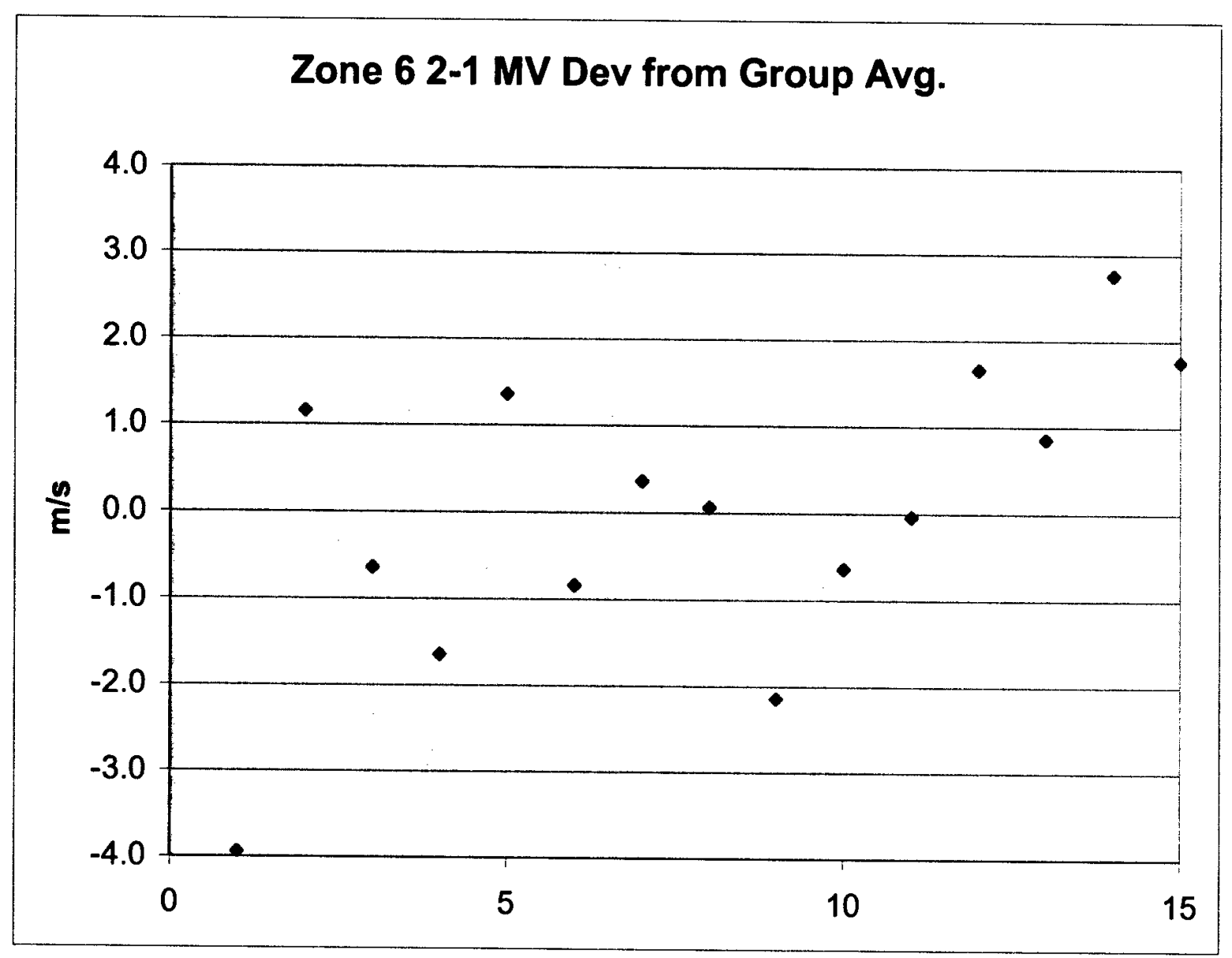




\begin{tabular}{|c|c|c|}
\hline $\begin{array}{c}\text { Zone 6 } \\
\text { Mission } \\
\text { ID }\end{array}$ & $\begin{array}{l}\text { Sampled } \\
\text { Increments } \\
\text { Temp @ }\end{array}$ & $\begin{array}{c}\text { Velocity } \\
\text { Measured - } \\
\text { Average } \\
\text { Velocity of } \\
\text { Group }\end{array}$ \\
\hline $2-2$ & 30.3 & -1.3 \\
\hline & 29.7 & -1.0 \\
\hline & 30.8 & -0.9 \\
\hline & 29.8 & 1.0 \\
\hline & 30.0 & 0.1 \\
\hline & 29.8 & -0.6 \\
\hline & 30.3 & -3.1 \\
\hline & 30.0 & 0.5 \\
\hline & 30.3 & 0.7 \\
\hline & 29.7 & -1.4 \\
\hline & & 0.1 \\
\hline & & 0.5 \\
\hline & & 1.0 \\
\hline & & 3.1 \\
\hline & & 1.3 \\
\hline
\end{tabular}

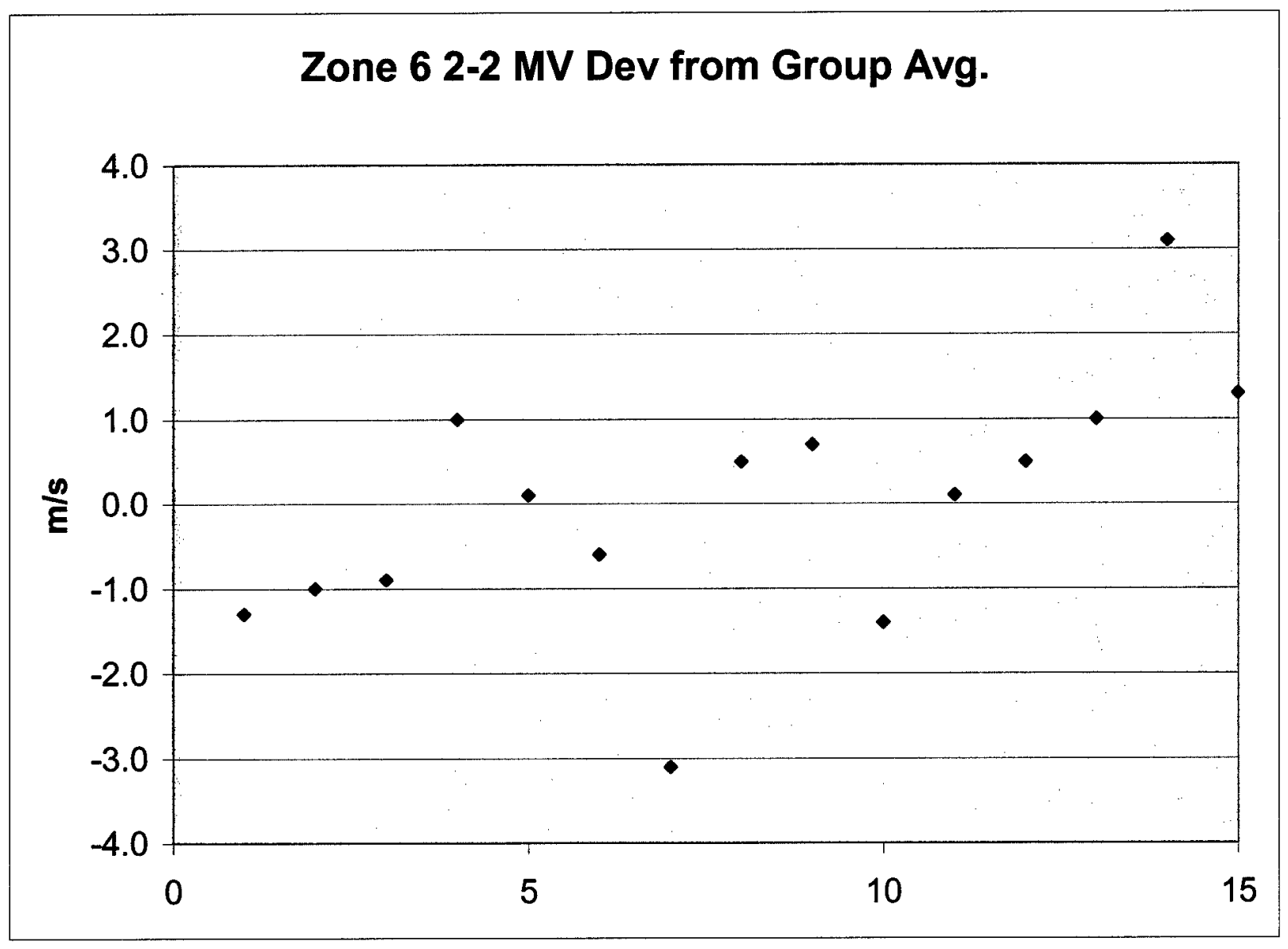




\begin{tabular}{|c|c|c|}
\hline zome 6 & $\begin{array}{c}\text { Velocity } \\
\text { Measured - } \\
\text { Average } \\
\text { Velocity of } \\
\text { Group }\end{array}$ \\
\hline $2-3$ & 32.8 & -1.5 \\
\hline & 32.1 & -1.7 \\
\hline & 33.2 & -2.0 \\
\hline & 31.9 & -5.0 \\
\hline & 30.6 & -1.8 \\
\hline & 30.9 & 1.4 \\
\hline & 30.8 & 1.2 \\
\hline & 32.1 & 0.8 \\
\hline & 31.9 & -6.5 \\
\hline & 31.7 & 3.2 \\
\hline & & 1.6 \\
\hline & & 3.1 \\
\hline & & 3.4 \\
\hline & & 2.2 \\
\hline & & 1.7 \\
\hline
\end{tabular}

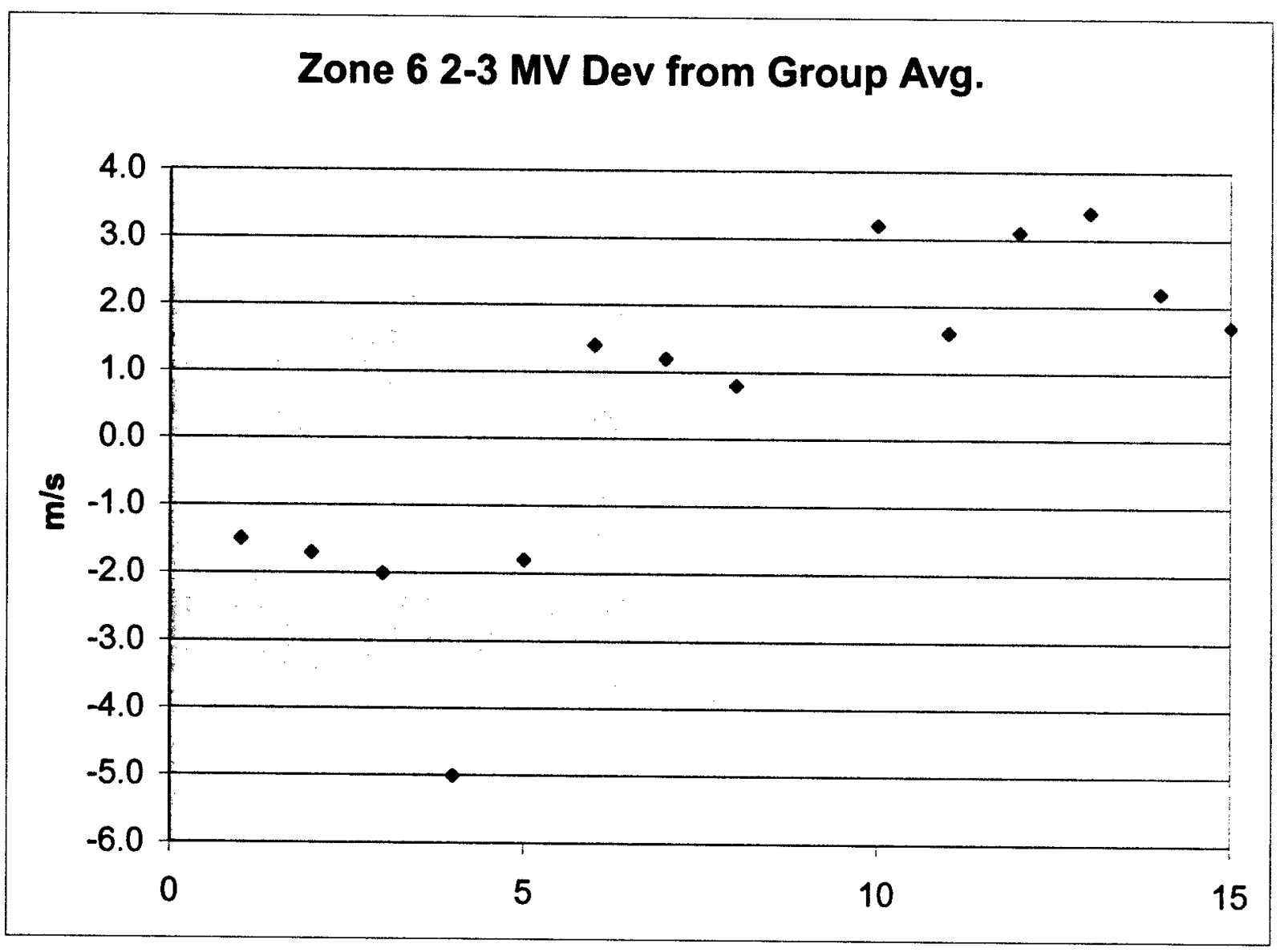




\begin{tabular}{|c|c|c|}
\hline $\begin{array}{c}\text { Zone 6 } \\
\text { Mission } \\
\text { ID }\end{array}$ & $\begin{array}{c}\text { Sampled } \\
\text { Increments } \\
\text { Temp @ }\end{array}$ & $\begin{array}{c}\text { Velocity } \\
\text { Measured - } \\
\text { Average } \\
\text { Velocity of } \\
\text { Group }\end{array}$ \\
\hline $2-4$ & 35.3 & 0.1 \\
\hline & 33.7 & -0.9 \\
\hline & 36.6 & 0.6 \\
\hline & 35.9 & -1.8 \\
\hline & 31.8 & -1.2 \\
\hline & 31.7 & -2.3 \\
\hline & 32.6 & -0.9 \\
\hline & 33.2 & -0.6 \\
\hline & 35.0 & 0.0 \\
\hline & 33.3 & 0.1 \\
\hline & & 2.6 \\
\hline & & 0.5 \\
\hline & & 1.4 \\
\hline & & 1.1 \\
\hline & & \#REF! \\
\hline
\end{tabular}

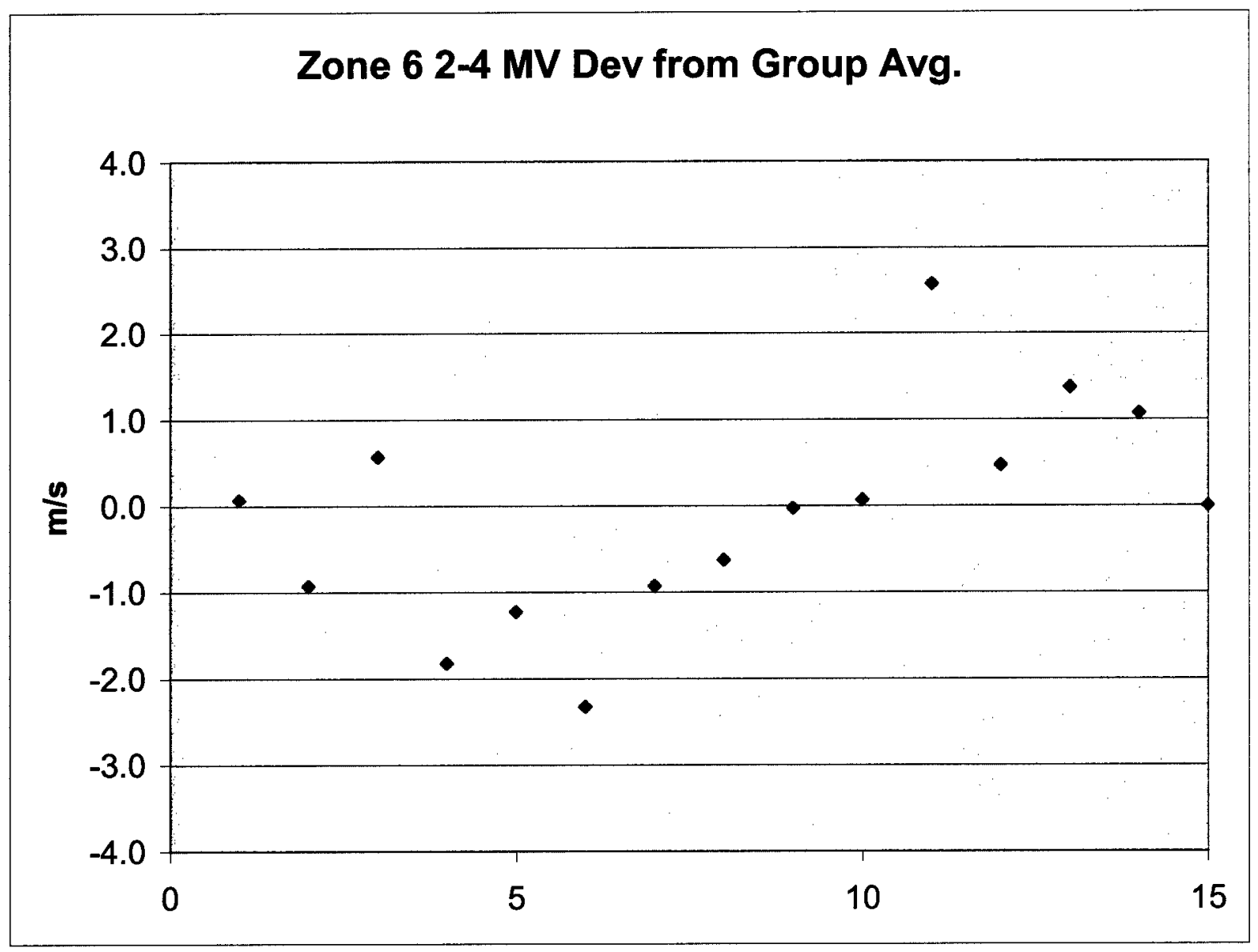




\begin{tabular}{|c|c|c|}
\hline & Valocity \\
zone e & $\begin{array}{c}\text { Sempled } \\
\text { Measured - } \\
\text { Average } \\
\text { Velocity of } \\
\text { Group }\end{array}$ \\
\hline $\mathbf{D}$ & Tenpe & -3.1 \\
\hline $3-1$ & 27.5 & -3.4 \\
\hline & 27.3 & -3.2 \\
\hline & 27.9 & -3 \\
\hline & 27.7 & 2.2 \\
\hline & 27.8 & 0.7 \\
\hline & 27.5 & 1.0 \\
\hline & 27.6 & 2.2 \\
\hline & 27.4 & 0.3 \\
\hline & 28.4 & 0.1 \\
\hline & 28.4 & 0.5 \\
\hline & & 1.3 \\
\hline & & 0.3 \\
\hline & & 2.0 \\
\hline & & 0.5 \\
\hline & & -1.0 \\
\hline
\end{tabular}

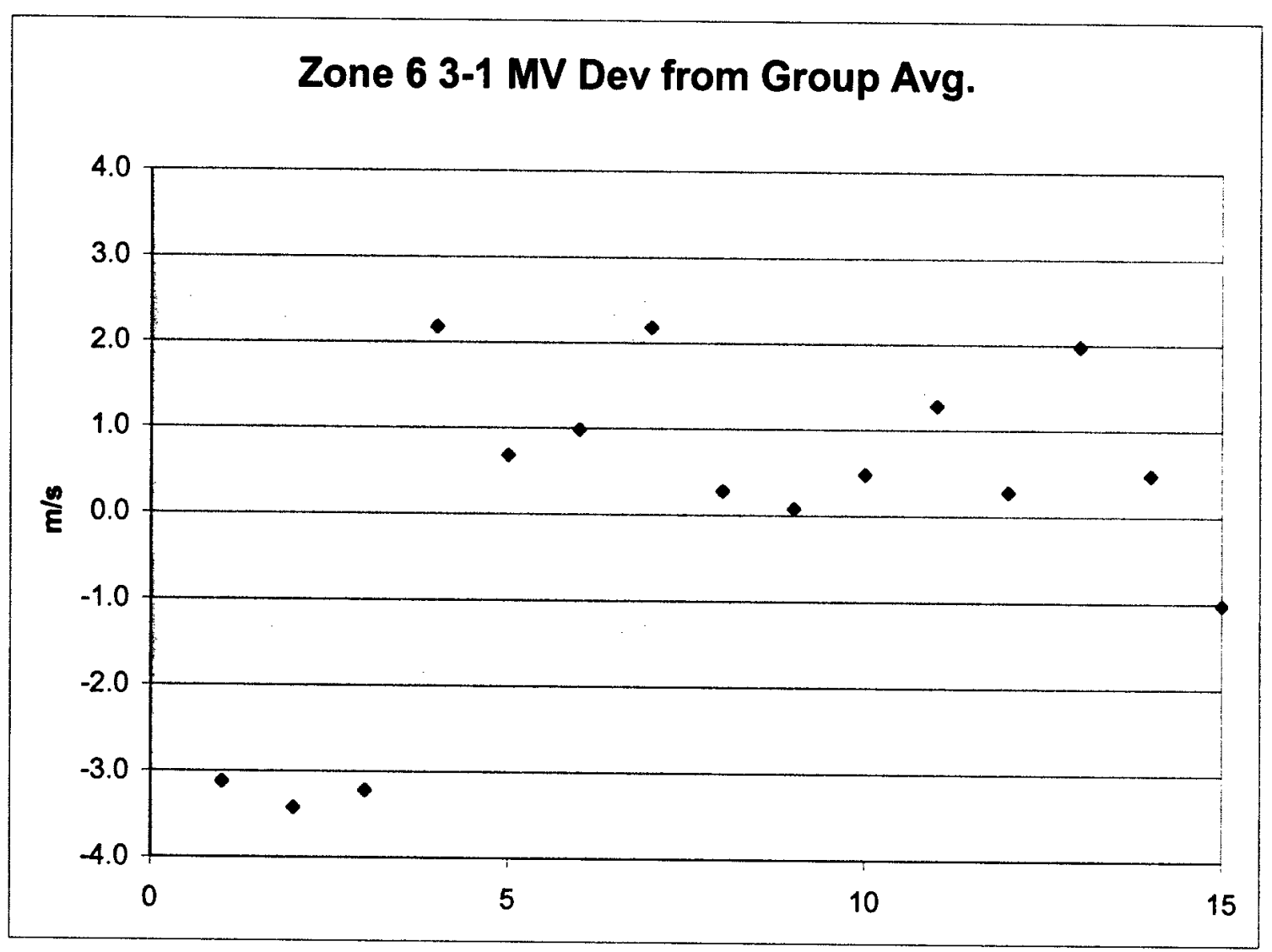




\begin{tabular}{|c|c|c|}
\hline $\begin{array}{c}\text { Zone 6 } \\
\text { Mission } \\
\text { ID }\end{array}$ & $\begin{array}{l}\text { Sampled } \\
\text { Increments } \\
\text { Temp @ }\end{array}$ & $\begin{array}{c}\text { Velocity } \\
\text { Measured - } \\
\text { Average } \\
\text { Velocity of } \\
\text { Group }\end{array}$ \\
\hline $3-2$ & 29.6 & -1.8 \\
\hline & 29.2 & 0.8 \\
\hline & 30.5 & -2.2 \\
\hline & 30.4 & 0.5 \\
\hline & 28.7 & 0.1 \\
\hline & 29.6 & 0.1 \\
\hline & 29.4 & 1.6 \\
\hline & 29.0 & 0.3 \\
\hline & 30.2 & -1.9 \\
\hline & 29.1 & -1.4 \\
\hline & & 0.3 \\
\hline & & 0.7 \\
\hline & & 1.8 \\
\hline & & 1.5 \\
\hline & & -0.2 \\
\hline
\end{tabular}

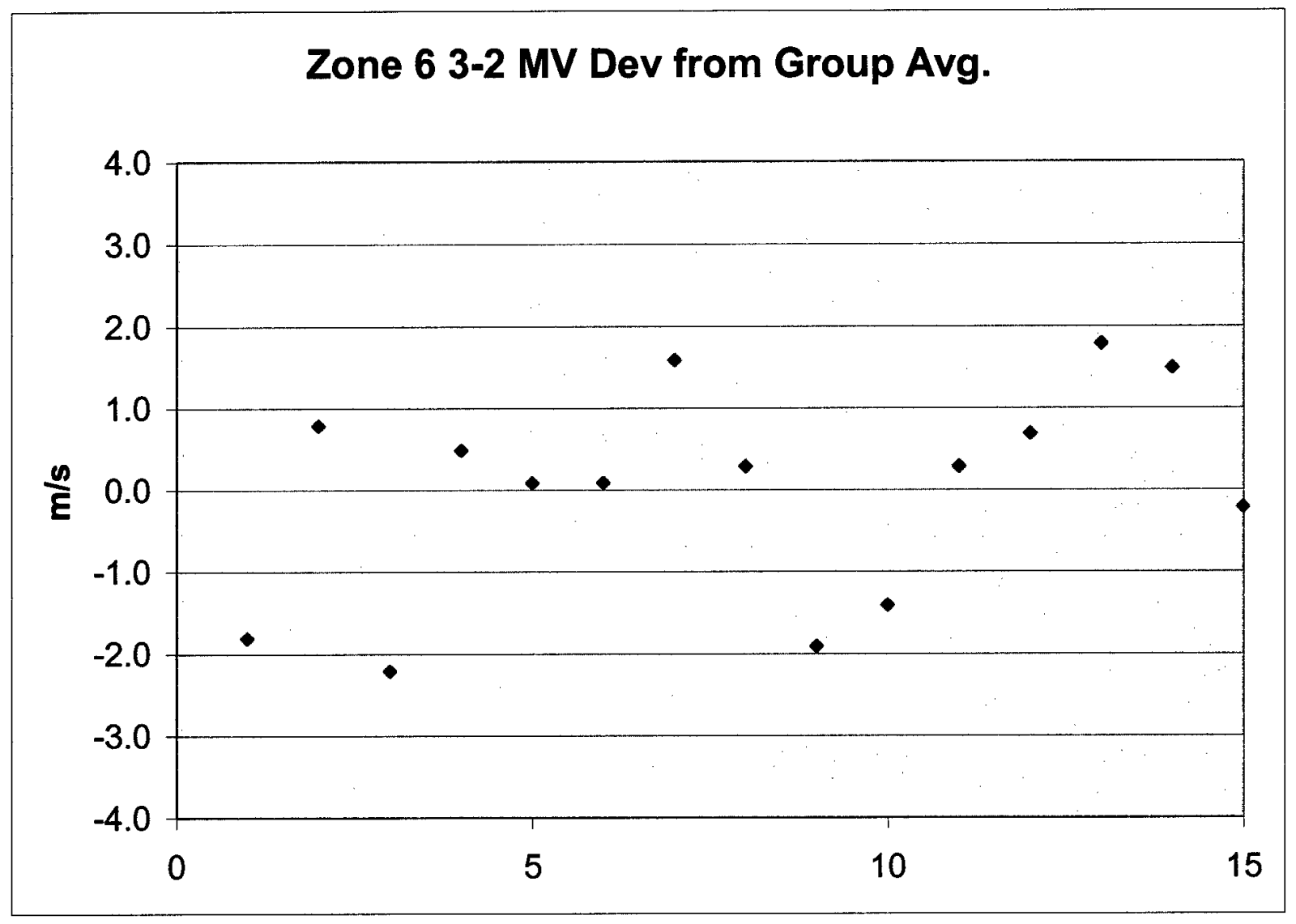




\begin{tabular}{|c|c|c|}
\hline $\begin{array}{c}200 n=6 \\
\text { minelen } \\
D\end{array}$ & $\begin{array}{l}\text { Sunifided } \\
\text { Inerements } \\
\text { Tempo }\end{array}$ & $\begin{array}{l}\text { Velocity } \\
\text { Measured - } \\
\text { Average } \\
\text { Veloctty of } \\
\text { Group }\end{array}$ \\
\hline \multirow[t]{15}{*}{$3-3$} & 31.8 & -1.1 \\
\hline & 30.8 & -0.7 \\
\hline & 32.6 & -1.3 \\
\hline & 30.7 & -1.3 \\
\hline & 29.8 & -0.3 \\
\hline & 30.2 & 0.4 \\
\hline & 29.7 & -1.2 \\
\hline & 29.4 & -1.1 \\
\hline & 29.6 & 0.5 \\
\hline & 29.7 & 0.9 \\
\hline & & 2.8 \\
\hline & & 2.3 \\
\hline & & 1.3 \\
\hline & & 0.3 \\
\hline & & -1.5 \\
\hline
\end{tabular}

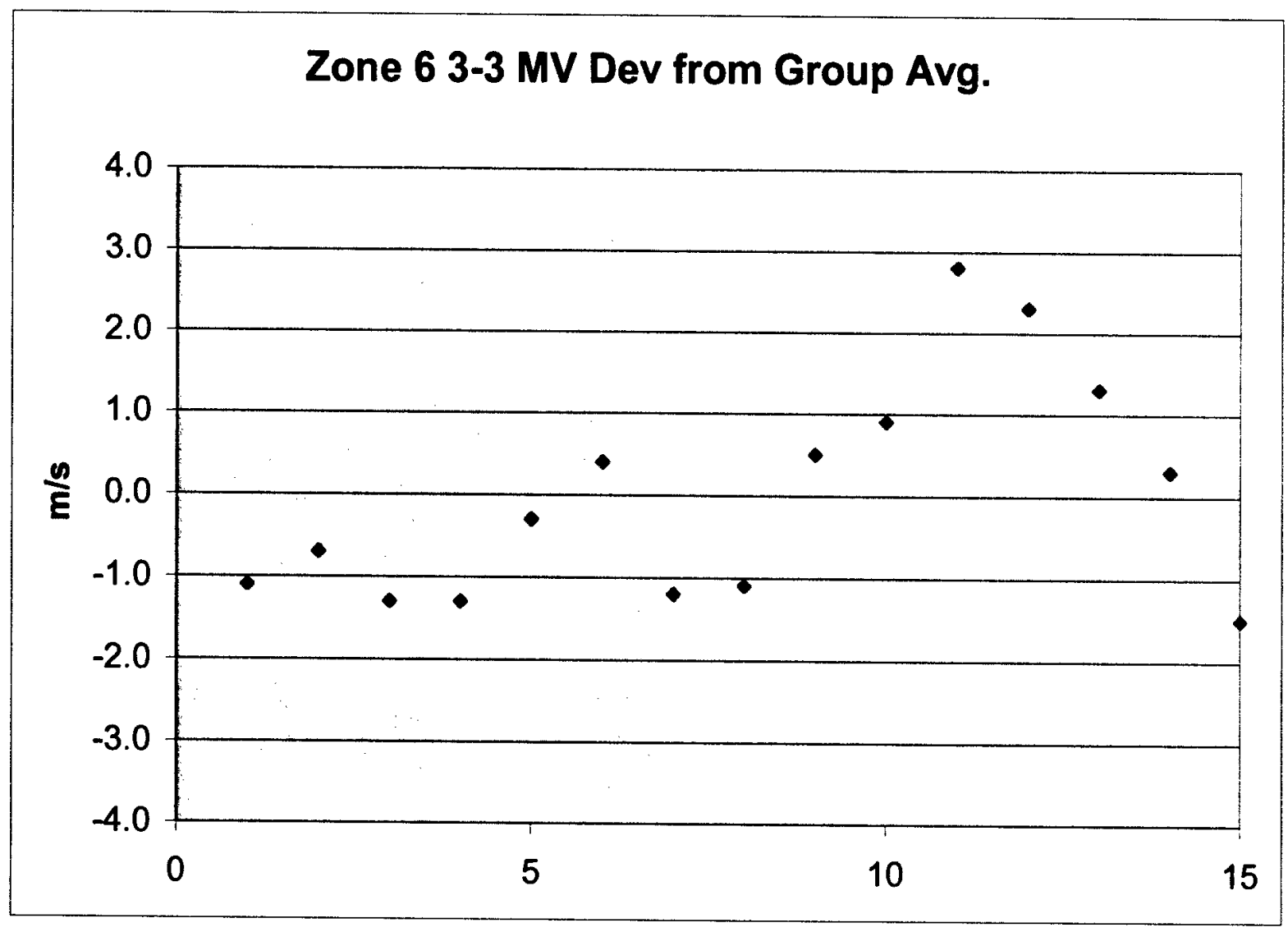




\begin{tabular}{|c|c|c|}
\hline $\begin{array}{c}\text { Zone 6 } \\
\text { Mission } \\
\text { ID }\end{array}$ & $\begin{array}{c}\text { Sampled } \\
\text { Increments } \\
\text { Temp O) }\end{array}$ & $\begin{array}{c}\text { Velocity } \\
\text { Measured - } \\
\text { Average } \\
\text { Velocity of } \\
\text { Group }\end{array}$ \\
\hline $3-4$ & 32.9 & -0.9 \\
\hline & 31.9 & -1.7 \\
\hline & 33.8 & -1.8 \\
\hline & 33.8 & -2.1 \\
\hline & 30.3 & 0.2 \\
\hline & 30.3 & -1.8 \\
\hline & 30.3 & 1.6 \\
\hline & 31.5 & 0.6 \\
\hline & 32.8 & -0.2 \\
\hline & 34.4 & 2.2 \\
\hline & & 1.8 \\
\hline & & -0.8 \\
\hline & & 0.7 \\
\hline & & -0.4 \\
\hline & & 2.7 \\
\hline
\end{tabular}

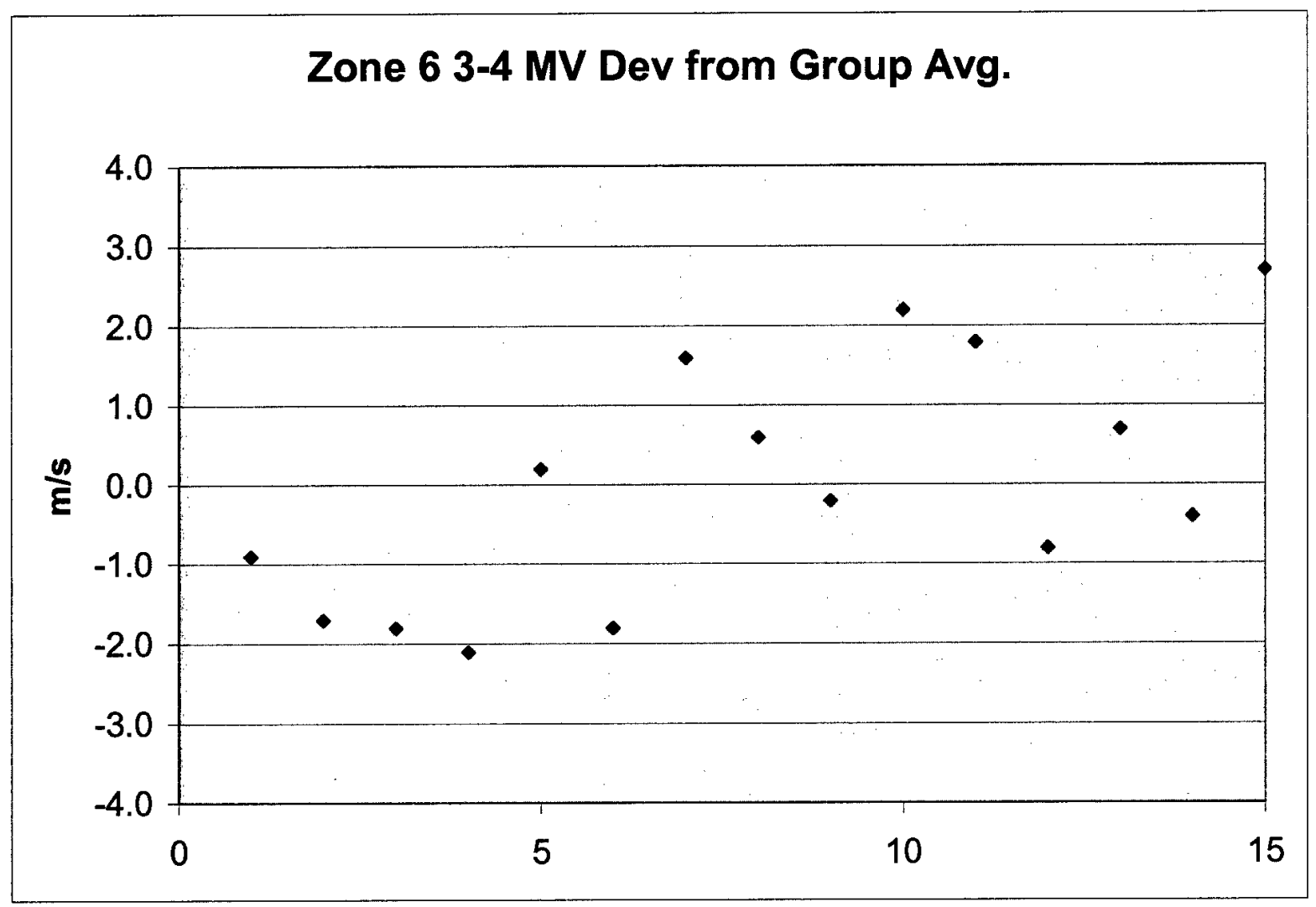




\begin{tabular}{|c|c|c|}
\hline $\begin{array}{c}\text { Zone } 6 \\
\text { inselon } \\
D\end{array}$ & $\begin{array}{l}\text { Sempled } \\
\text { horements } \\
\text { Tempe }\end{array}$ & $\begin{array}{l}\text { Velocity } \\
\text { Measured - } \\
\text { Average } \\
\text { Velocity of } \\
\text { Group }\end{array}$ \\
\hline \multirow[t]{15}{*}{$4-2$} & 35.1 & -3.1 \\
\hline & 34.5 & -0.5 \\
\hline & 35.5 & -0.5 \\
\hline & 34.1 & 1.6 \\
\hline & 32.7 & -5.4 \\
\hline & 32.7 & 0.7 \\
\hline & 32.7 & 1.9 \\
\hline & 32.6 & -1.1 \\
\hline & 33.9 & 1.6 \\
\hline & 32.7 & 0.3 \\
\hline & & 0.1 \\
\hline & & 0.5 \\
\hline & & 0.1 \\
\hline & & 2.4 \\
\hline & & 0.7 \\
\hline
\end{tabular}

\section{Zone 6 4-2 MV Dev from Group Avg.}

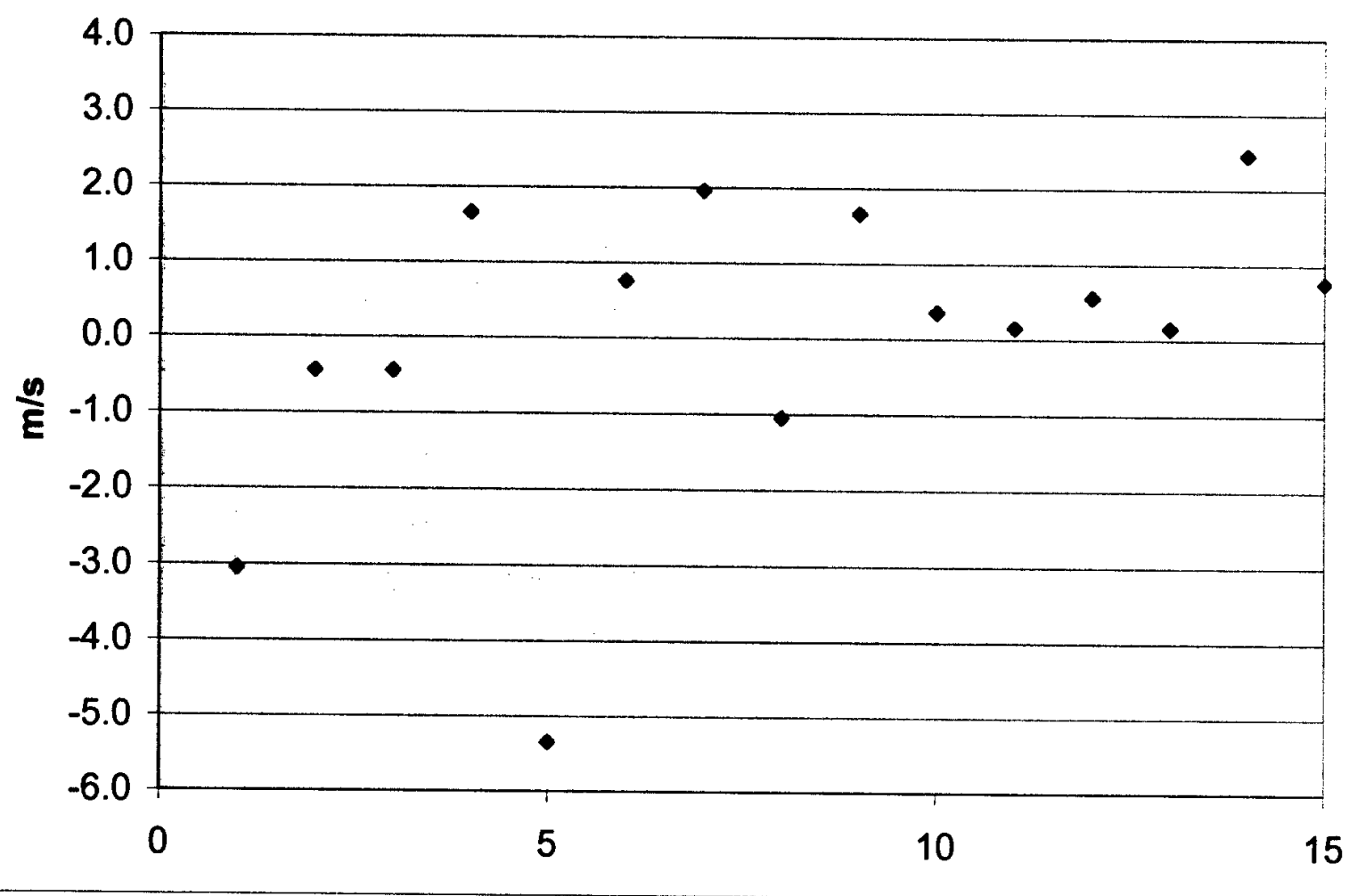




\begin{tabular}{|c|c|c|}
\hline $\begin{array}{c}\text { Zone 6 } \\
\text { Mission } \\
\text { ID }\end{array}$ & $\begin{array}{c}\text { Sampled } \\
\text { increments } \\
\text { Temp @ }\end{array}$ & $\begin{array}{c}\text { Velocity } \\
\text { Measured - } \\
\text { Average } \\
\text { Velocity of } \\
\text { Group }\end{array}$ \\
\hline $5-1$ & 32.3 & -0.8 \\
\hline & 31.1 & 2.2 \\
\hline & 33.3 & 0.2 \\
\hline & 31.7 & 1.1 \\
\hline & 31.8 & 0.5 \\
\hline & 31.8 & -0.7 \\
\hline & 32.0 & 0.9 \\
\hline & 31.3 & 0.3 \\
\hline & 33.2 & 0.4 \\
\hline & 31.8 & -1.2 \\
\hline & & 0.7 \\
\hline & & -0.9 \\
\hline & & -2.2 \\
\hline & & -0.4 \\
\hline & & -0.6 \\
\hline
\end{tabular}

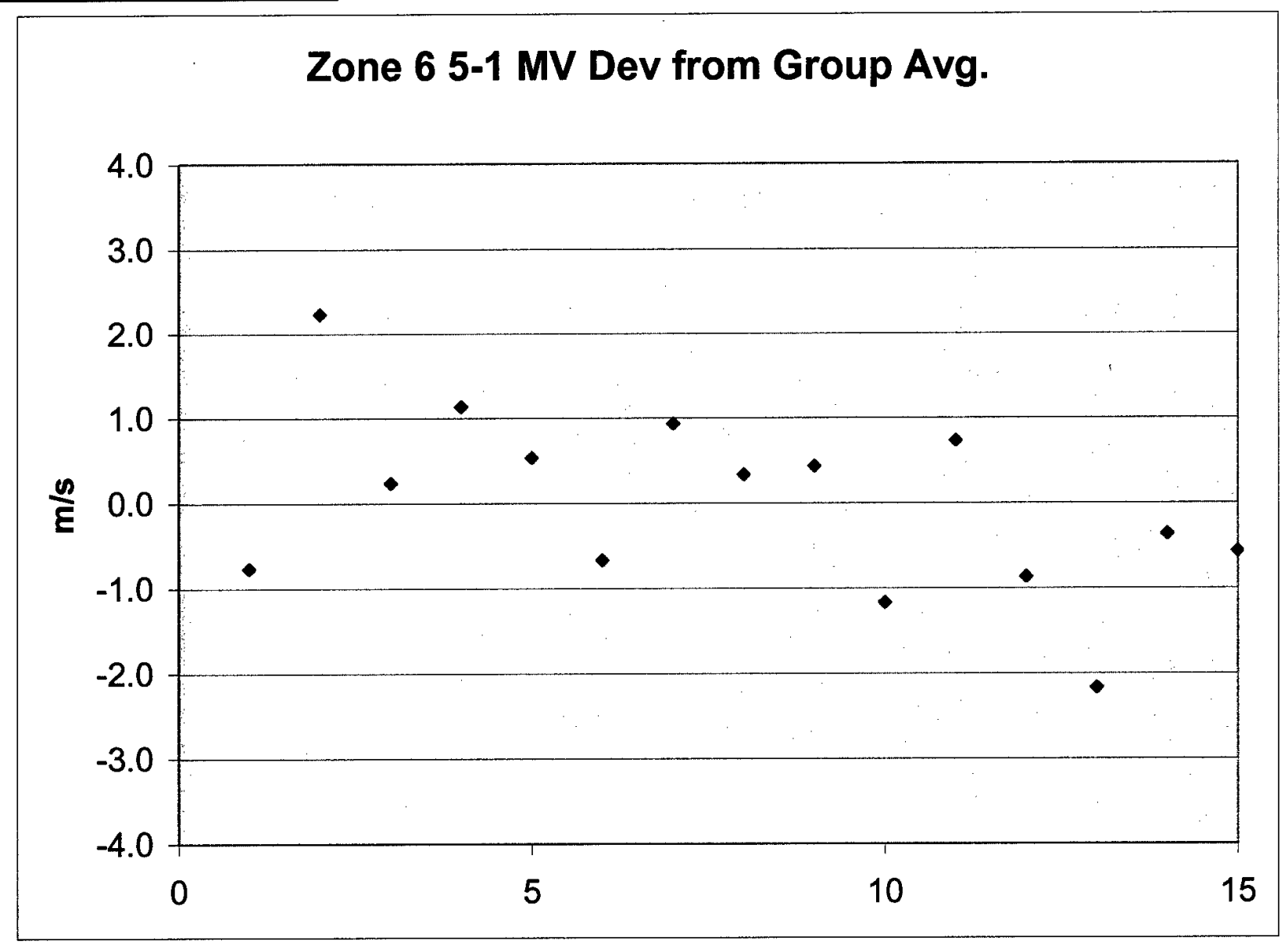




\begin{tabular}{|c|c|c|}
\hline & Velocity \\
zones & $\begin{array}{c}\text { Sumpled } \\
\text { Measured - } \\
\text { Average } \\
\text { Veloctly of } \\
\text { Group }\end{array}$ \\
\hline $5-2$ & 34.9 & 2.2 \\
\hline & 33.2 & 1.3 \\
\hline & 34.8 & 0.7 \\
\hline & 33.7 & 1.7 \\
\hline & 33.6 & 0.5 \\
\hline & 32.6 & 0.5 \\
\hline & 32.2 & -0.1 \\
\hline & 32.4 & -0.6 \\
\hline & 33.6 & -0.7 \\
\hline & 32.8 & 1.1 \\
\hline & & -1.0 \\
\hline & & -1.6 \\
\hline & & -2.2 \\
\hline & & -0.6 \\
\hline & & -0.8 \\
\hline
\end{tabular}

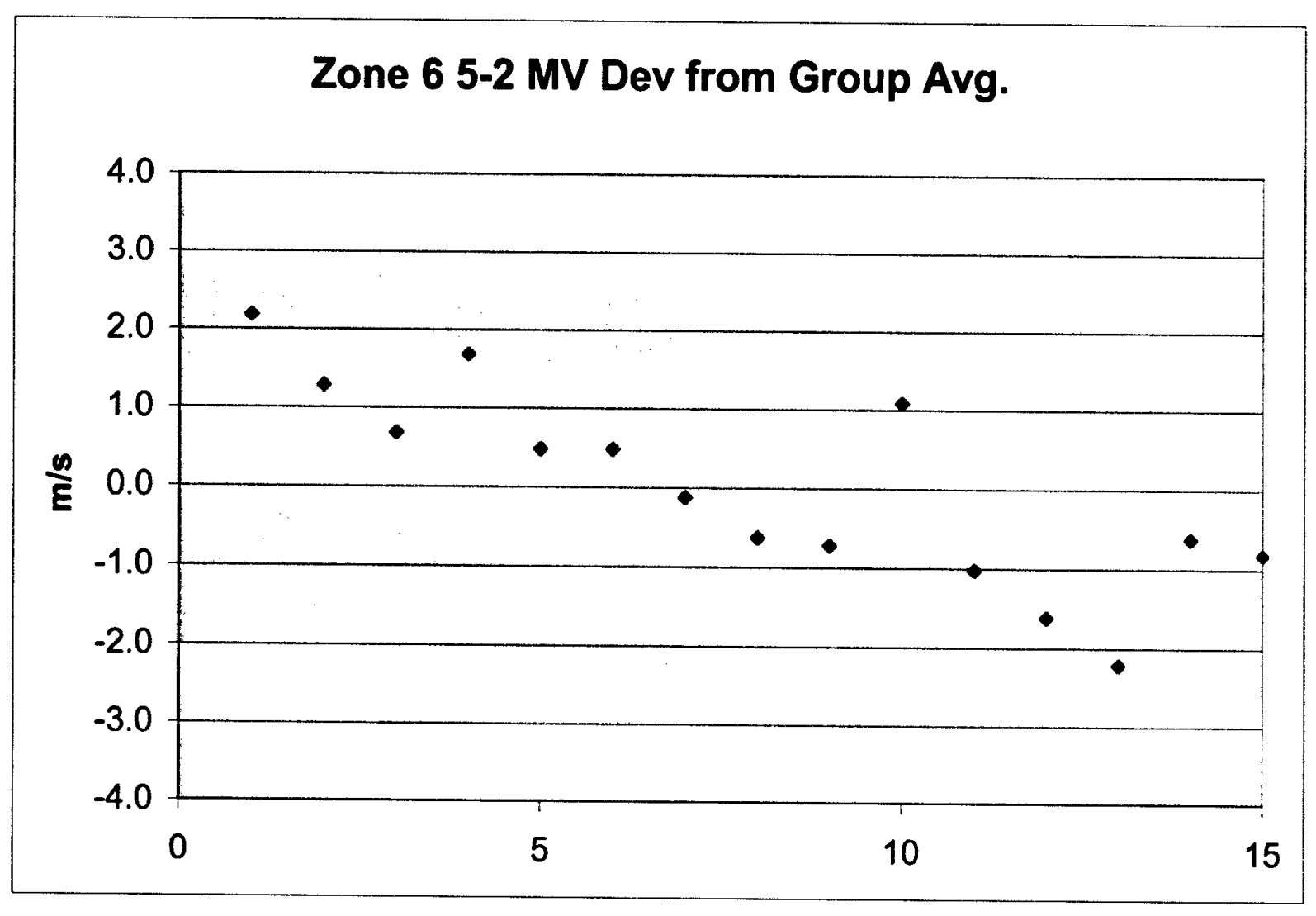




\begin{tabular}{|c|c|c|}
\hline $\begin{array}{c}\text { Zone 6 } \\
\text { Mission } \\
\text { ID }\end{array}$ & $\begin{array}{c}\text { Sampled } \\
\text { Increments } \\
\text { Temp @ }\end{array}$ & $\begin{array}{c}\text { Velocity } \\
\text { Measured - } \\
\text { Average } \\
\text { Velocity of } \\
\text { Group }\end{array}$ \\
\hline $5-3$ & 39.9 & -2.3 \\
\hline & 37.7 & -0.3 \\
\hline & 40.9 & -1.0 \\
\hline & 37.9 & -0.6 \\
\hline & 35.4 & -1.2 \\
\hline & 35.7 & -1.5 \\
\hline & 36.4 & -2.7 \\
\hline & 35.6 & -0.4 \\
\hline & 37.1 & 0.3 \\
\hline & 36.5 & -0.7 \\
\hline & & 2.1 \\
\hline & & 2.3 \\
\hline & & 2.5 \\
\hline & & 1.9 \\
\hline & & 1.2 \\
\hline
\end{tabular}

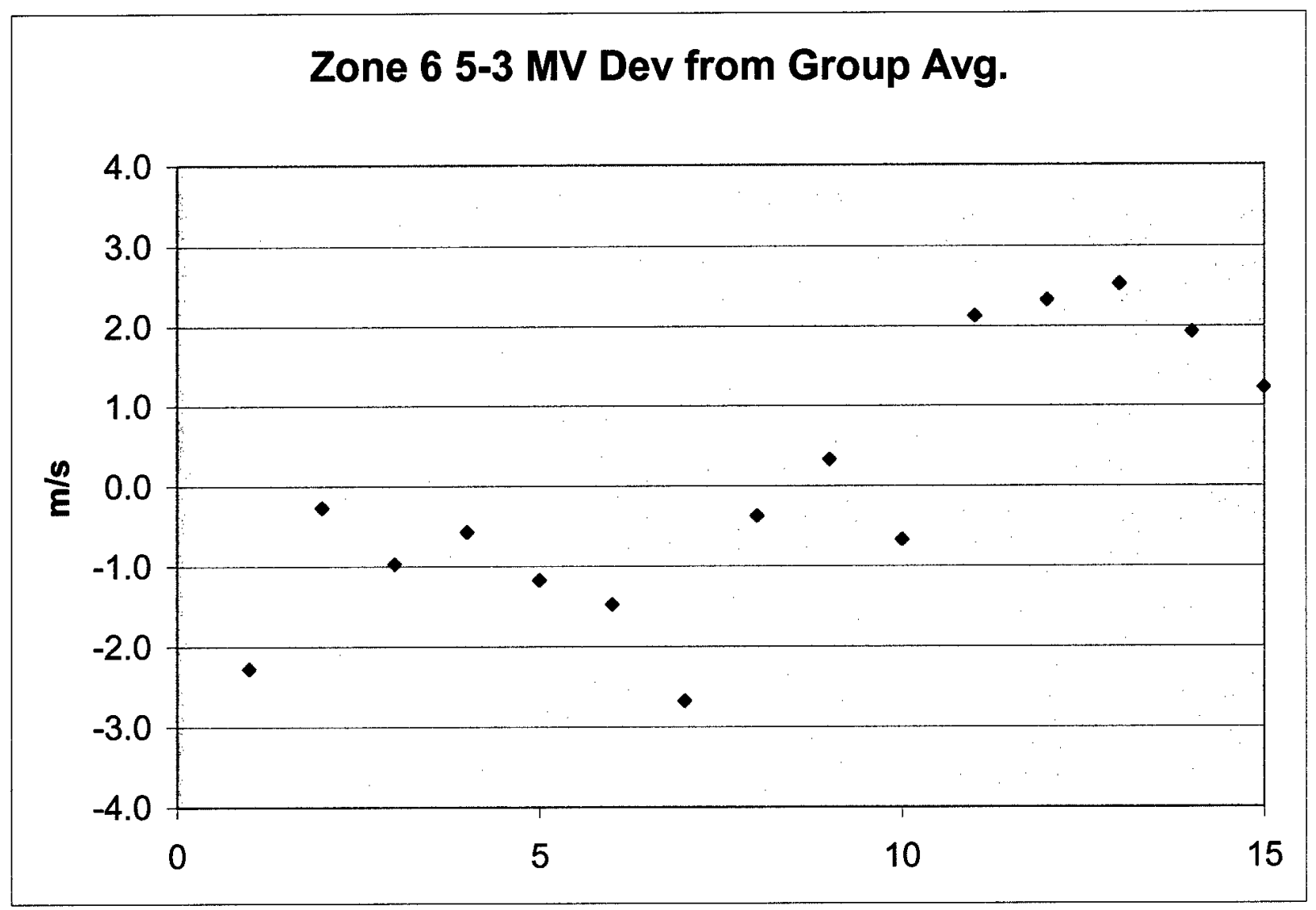




\begin{tabular}{|c|c|c|}
\hline $\begin{array}{c}\text { zome } 6 \\
\text { mileilon } \\
0\end{array}$ & $\begin{array}{l}\text { Sampled } \\
\text { herements } \\
\text { Tempe }\end{array}$ & $\begin{array}{l}\text { Veccity } \\
\text { Measured - } \\
\text { Average } \\
\text { Veloctly of } \\
\text { Group }\end{array}$ \\
\hline \multirow[t]{15}{*}{$5-4$} & 41.8 & 0.2 \\
\hline & 41.3 & -1.2 \\
\hline & 44.2 & -1.3 \\
\hline & 43.0 & 1.2 \\
\hline & 37.5 & -3.2 \\
\hline & 37.1 & -0.2 \\
\hline & 37.3 & -1.6 \\
\hline & 40.4 & 2.0 \\
\hline & 40.3 & 0.2 \\
\hline & 38.3 & -0.6 \\
\hline & & 0.3 \\
\hline & & -0.7 \\
\hline & & 2.2 \\
\hline & & 1.1 \\
\hline & & 1.1 \\
\hline
\end{tabular}

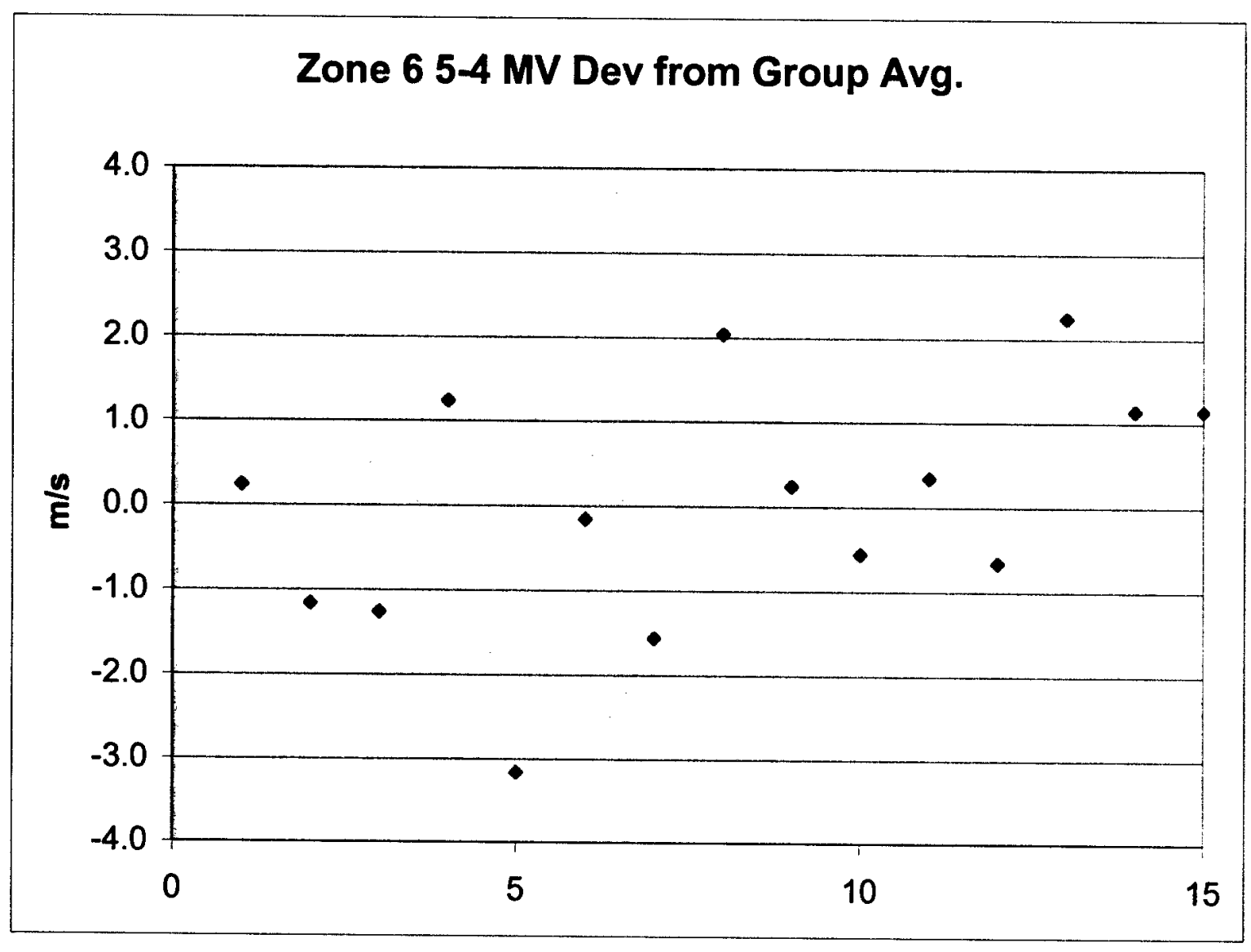




\begin{tabular}{|c|c|c|}
\hline $\begin{array}{c}\text { Zone 6 } \\
\text { Mission } \\
\text { ID }\end{array}$ & $\begin{array}{l}\text { Sampled } \\
\text { Increments } \\
\text { Temp } \odot\end{array}$ & $\begin{array}{c}\text { Velocity } \\
\text { Measured - } \\
\text { Average } \\
\text { Velocity of } \\
\text { Group }\end{array}$ \\
\hline $7-1$ & 27.2 & -1.7 \\
\hline & 27.8 & -0.2 \\
\hline & 27.3 & -0.4 \\
\hline & 27.3 & 0.3 \\
\hline & 28.3 & 1.2 \\
\hline & 28.7 & 1.4 \\
\hline & 27.9 & 0.0 \\
\hline & 28.0 & -3.5 \\
\hline & 28.0 & 0.8 \\
\hline & 27.1 & 0.6 \\
\hline & & -0.9 \\
\hline & & 0.6 \\
\hline & & 1.4 \\
\hline & & 0.0 \\
\hline & & 0.3 \\
\hline
\end{tabular}

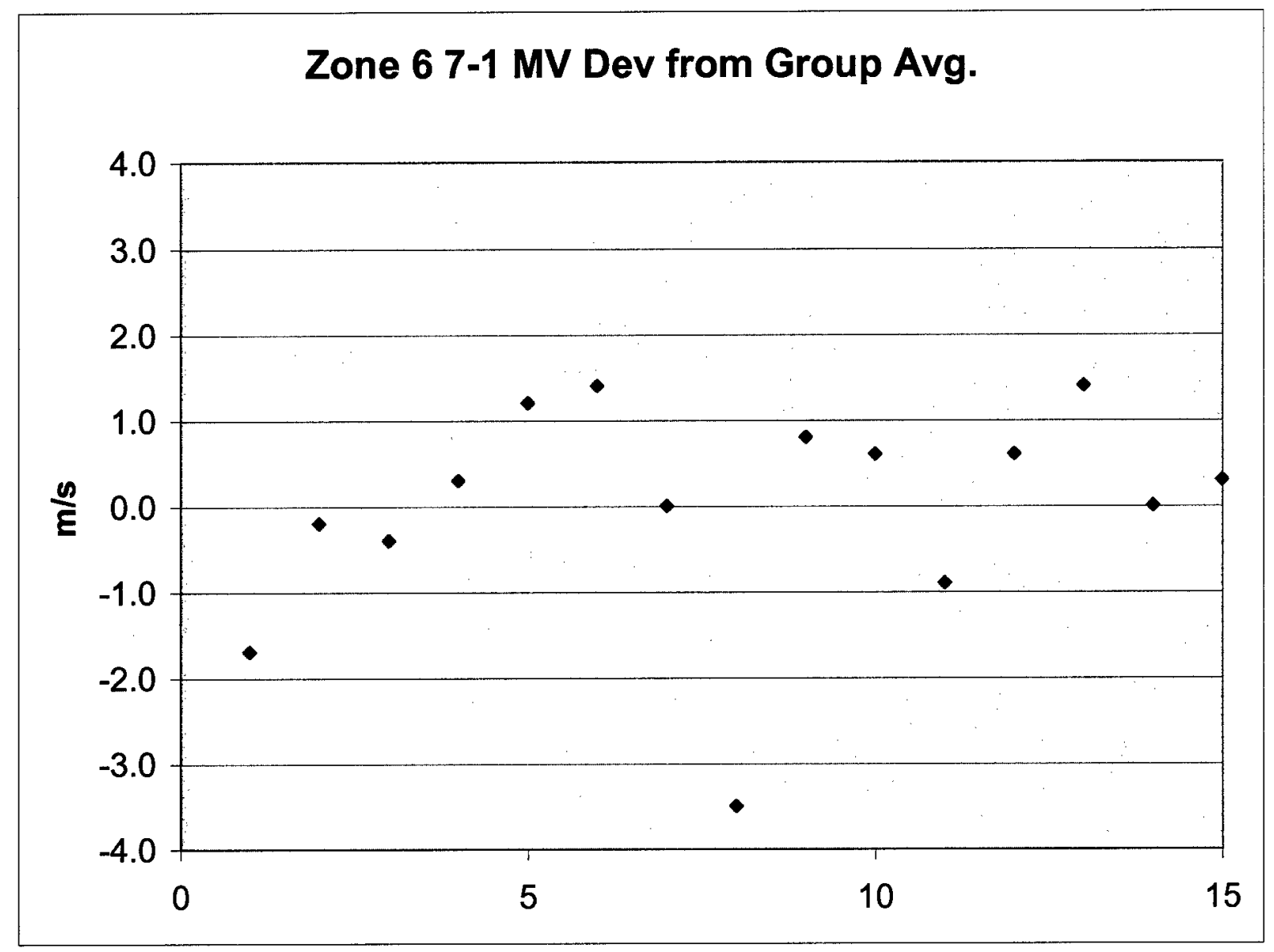




\begin{tabular}{|c|c|c|}
\hline & zone 8 & $\begin{array}{c}\text { Velocity } \\
\text { Measured - } \\
\text { Average } \\
\text { Velocity of } \\
\text { Group }\end{array}$ \\
\hline 7.2 & 29.3 & 0.4 \\
\hline & 28.7 & 0.7 \\
\hline & 29.1 & 0.2 \\
\hline & 28.8 & -2.9 \\
\hline & 29.1 & -1.2 \\
\hline & 29.3 & -0.9 \\
\hline & 29.2 & -3.4 \\
\hline & 29.3 & -1.6 \\
\hline & 29.6 & 1.2 \\
\hline & 28.5 & 0.7 \\
\hline & & -0.1 \\
\hline & & 0.3 \\
\hline & & 2.6 \\
\hline & & 3.1 \\
\hline & & 0.3 \\
\hline
\end{tabular}

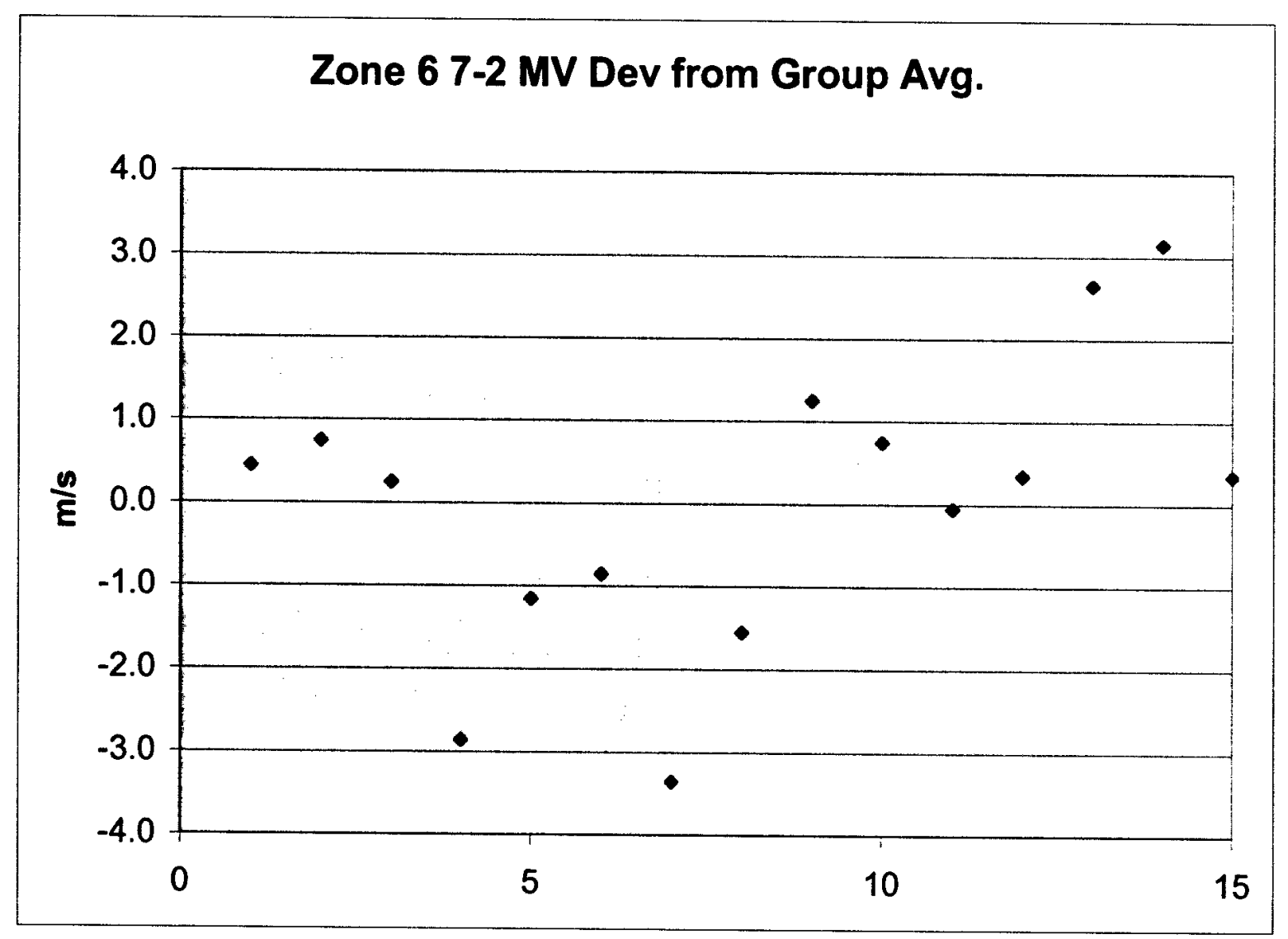




\begin{tabular}{|c|c|c|}
\hline $\begin{array}{c}\text { Zone 6 } \\
\text { Mission } \\
\text { ID }\end{array}$ & $\begin{array}{l}\text { Sampled } \\
\text { Increments } \\
\text { Temp O }\end{array}$ & $\begin{array}{c}\text { Velocity } \\
\text { Measured - } \\
\text { Average } \\
\text { Velocity of } \\
\text { Group }\end{array}$ \\
\hline $7-3$ & 30.6 & 0.6 \\
\hline & 30.9 & 0.4 \\
\hline & 31.6 & -1.7 \\
\hline & 29.9 & -0.9 \\
\hline & 29.8 & 2.1 \\
\hline & 30.2 & 1.1 \\
\hline & 29.6 & -0.2 \\
\hline & 29.9 & 0.0 \\
\hline & 32.6 & 0.6 \\
\hline & 29.9 & -1.4 \\
\hline & & 0.2 \\
\hline & & -1.0 \\
\hline & & 0.2 \\
\hline & & -1.6 \\
\hline & & 1.3 \\
\hline
\end{tabular}

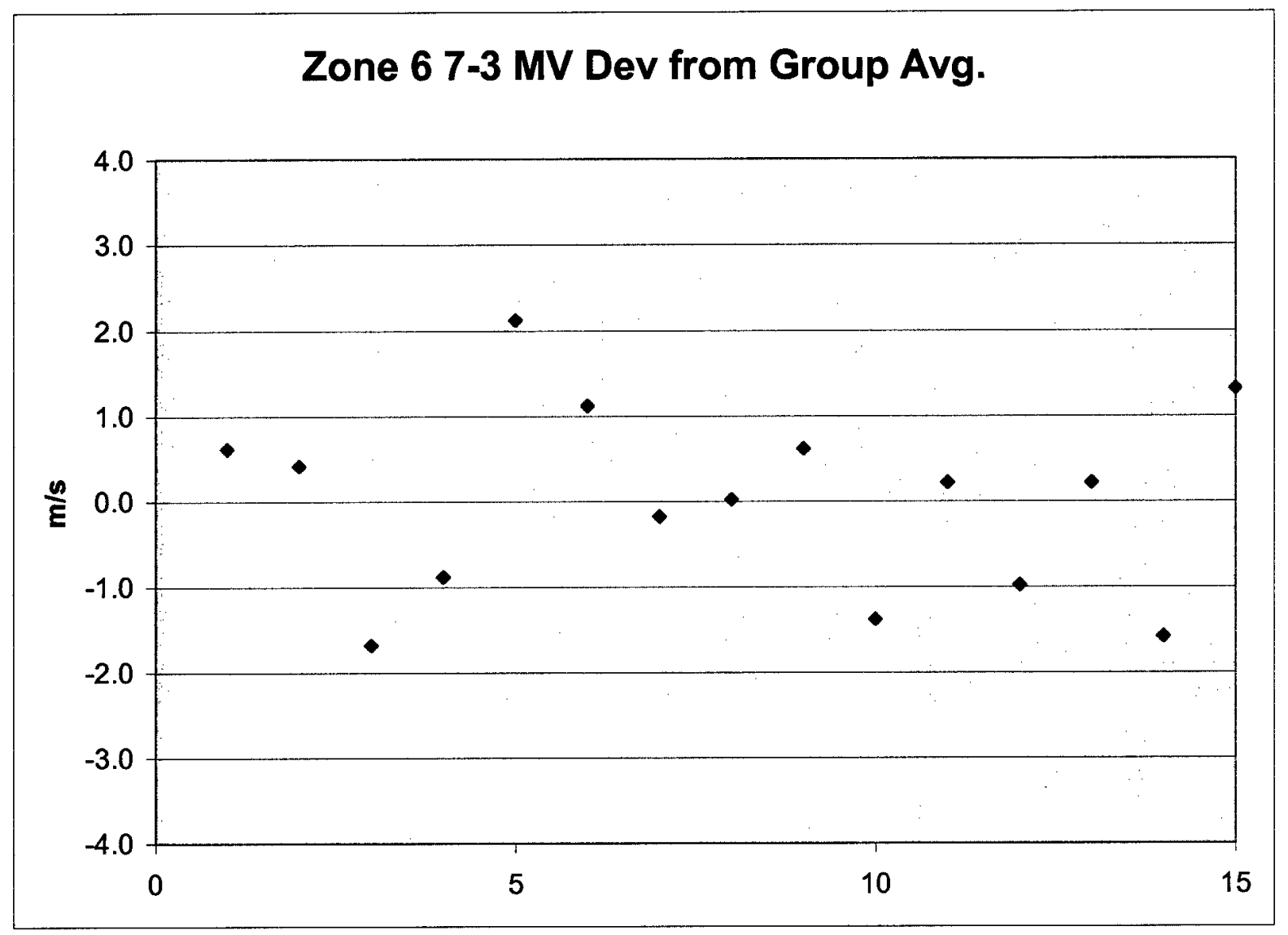




\begin{tabular}{|c|c|c|}
\hline Zone & Sompind & $\begin{array}{c}\text { Velocity } \\
\text { Measured - } \\
\text { Average } \\
\text { Velocity of } \\
\text { Group }\end{array}$ \\
\hline $7-4$ & 33.9 & 0.3 \\
\hline & 32.5 & 1.1 \\
\hline & 33.4 & 2.3 \\
\hline & 34.2 & -2.6 \\
\hline & 30.6 & -0.2 \\
\hline & 30.6 & -0.5 \\
\hline & 30.4 & -0.5 \\
\hline & 31.5 & 0.8 \\
\hline & 33.7 & 0.7 \\
\hline & 32.0 & 2.0 \\
\hline & & -1.4 \\
\hline & & -1.4 \\
\hline & & -1.2 \\
\hline & & 0.4 \\
\hline & & -0.2 \\
\hline
\end{tabular}

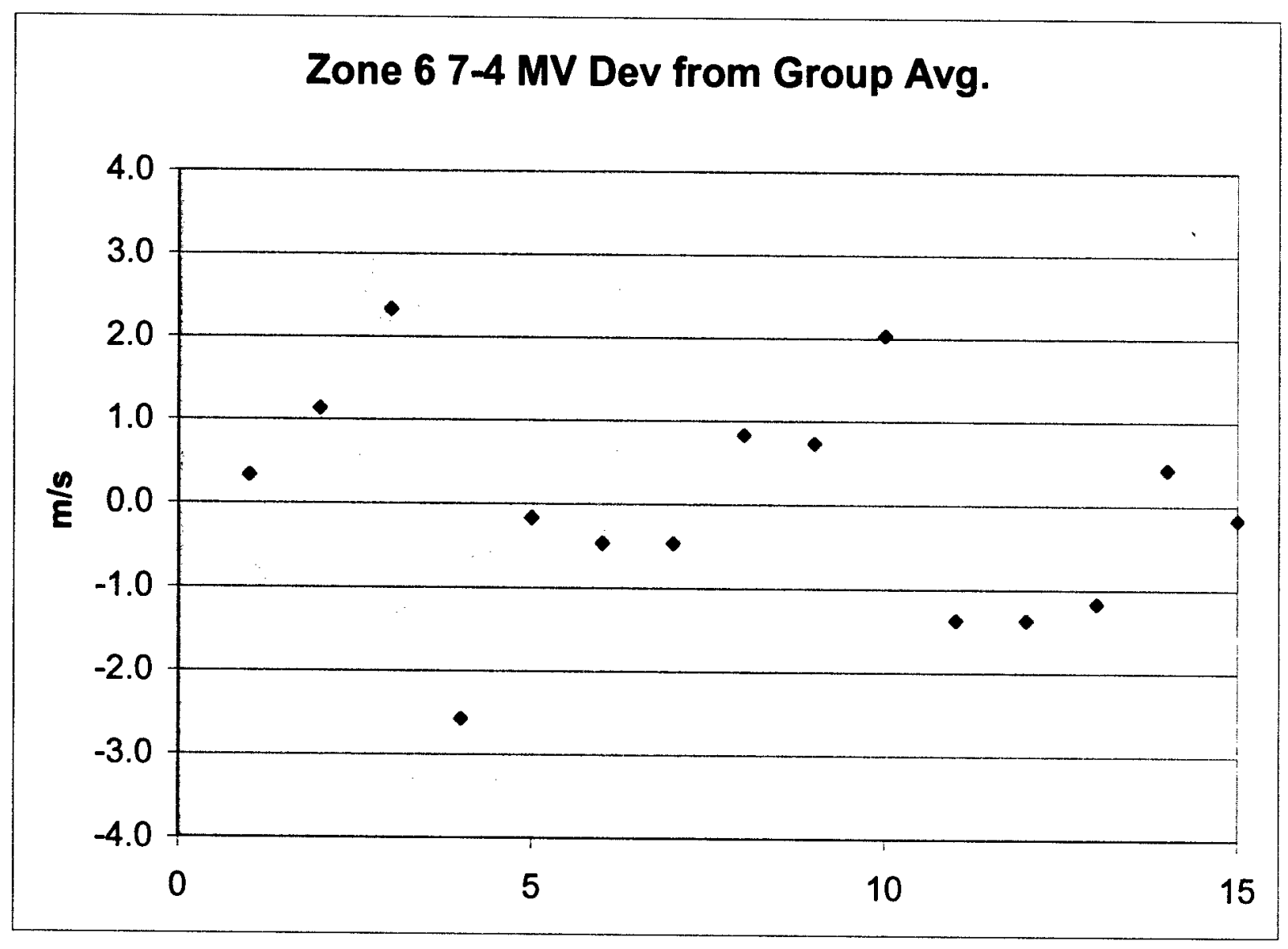




\begin{tabular}{|c|c|c|}
\hline $\begin{array}{c}\text { Zone 6 } \\
\text { Mission } \\
\text { ID }\end{array}$ & $\begin{array}{c}\text { Sampled } \\
\text { Increments } \\
\text { Temp @) }\end{array}$ & $\begin{array}{c}\text { Velocity } \\
\text { Measured - } \\
\text { Average } \\
\text { Velocity of } \\
\text { Group }\end{array}$ \\
\hline $8-1$ & 41.4 & 0.2 \\
\hline & 40.3 & -0.6 \\
\hline & 38.7 & 1.6 \\
\hline & 37.4 & 2.4 \\
\hline & 35.1 & -0.3 \\
\hline & 36.2 & -1.1 \\
\hline & 35.3 & -1.7 \\
\hline & 36.1 & -1.5 \\
\hline & 37.4 & -1.7 \\
\hline & 36.1 & 2.7 \\
\hline & & 0.3 \\
\hline & & -1.5 \\
\hline & & 0.1 \\
\hline & & -2.3 \\
\hline & & 3.9 \\
\hline
\end{tabular}

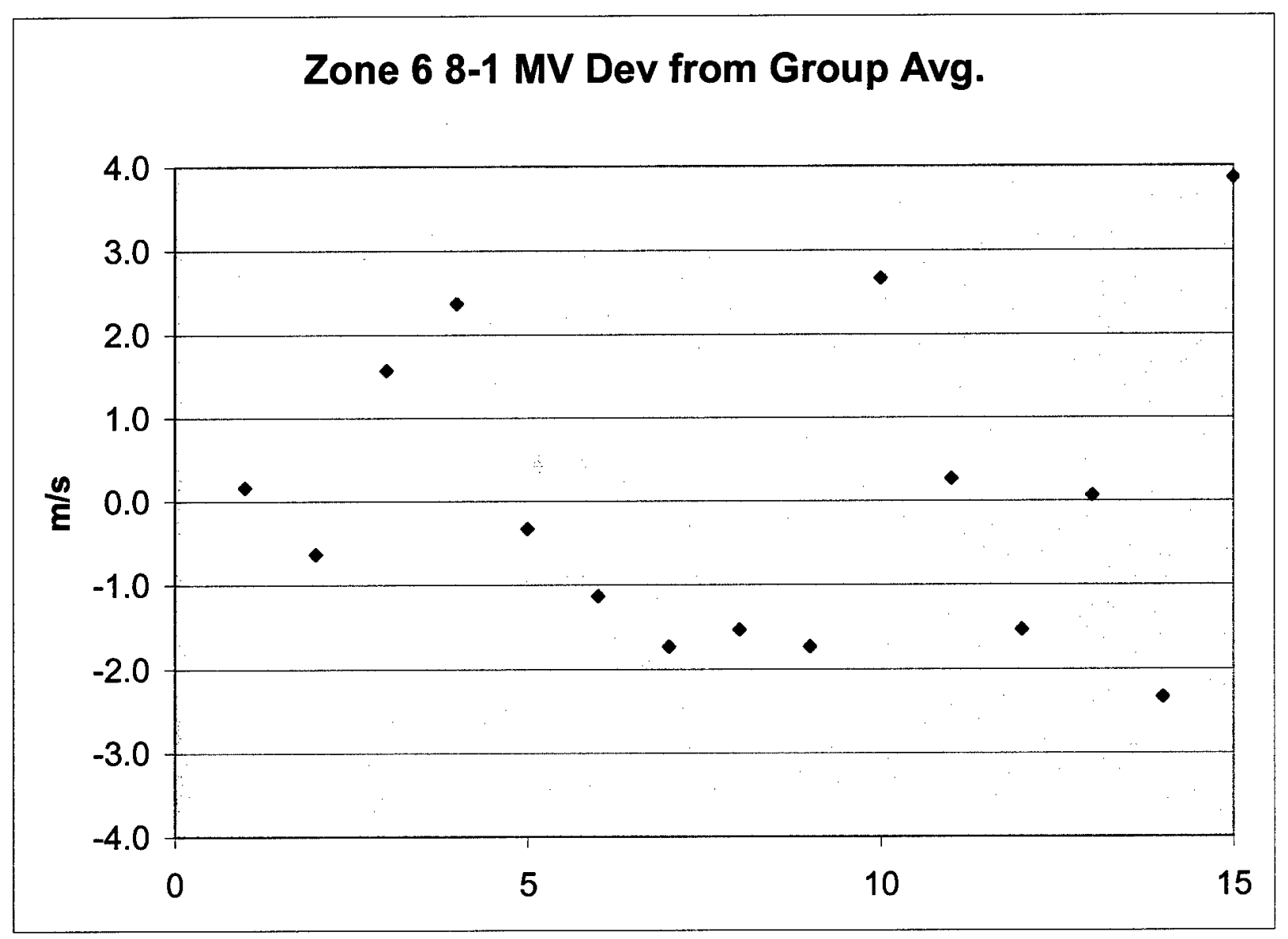




\begin{tabular}{|c|c|c|}
\hline Zlome 6 & $\begin{array}{l}\text { Sempled } \\
\text { nonements } \\
\text { Tempe }\end{array}$ & $\begin{array}{l}\text { Velocity } \\
\text { Measured - } \\
\text { Average } \\
\text { Veloclty of } \\
\text { Group }\end{array}$ \\
\hline $8-1$ & 41.4 & 0.2 \\
\hline & 40.3 & -0.6 \\
\hline & 38.7 & 1.6 \\
\hline & 37.4 & 2.4 \\
\hline & 35.1 & -0.3 \\
\hline & 36.2 & -1.1 \\
\hline & 35.3 & -1.7 \\
\hline & 36.1 & -1.5 \\
\hline & 37.4 & -1.7 \\
\hline & 36.1 & 2.7 \\
\hline & & 0.3 \\
\hline & & -1.5 \\
\hline & & 0.1 \\
\hline & & -2.3 \\
\hline & & 3.9 \\
\hline
\end{tabular}

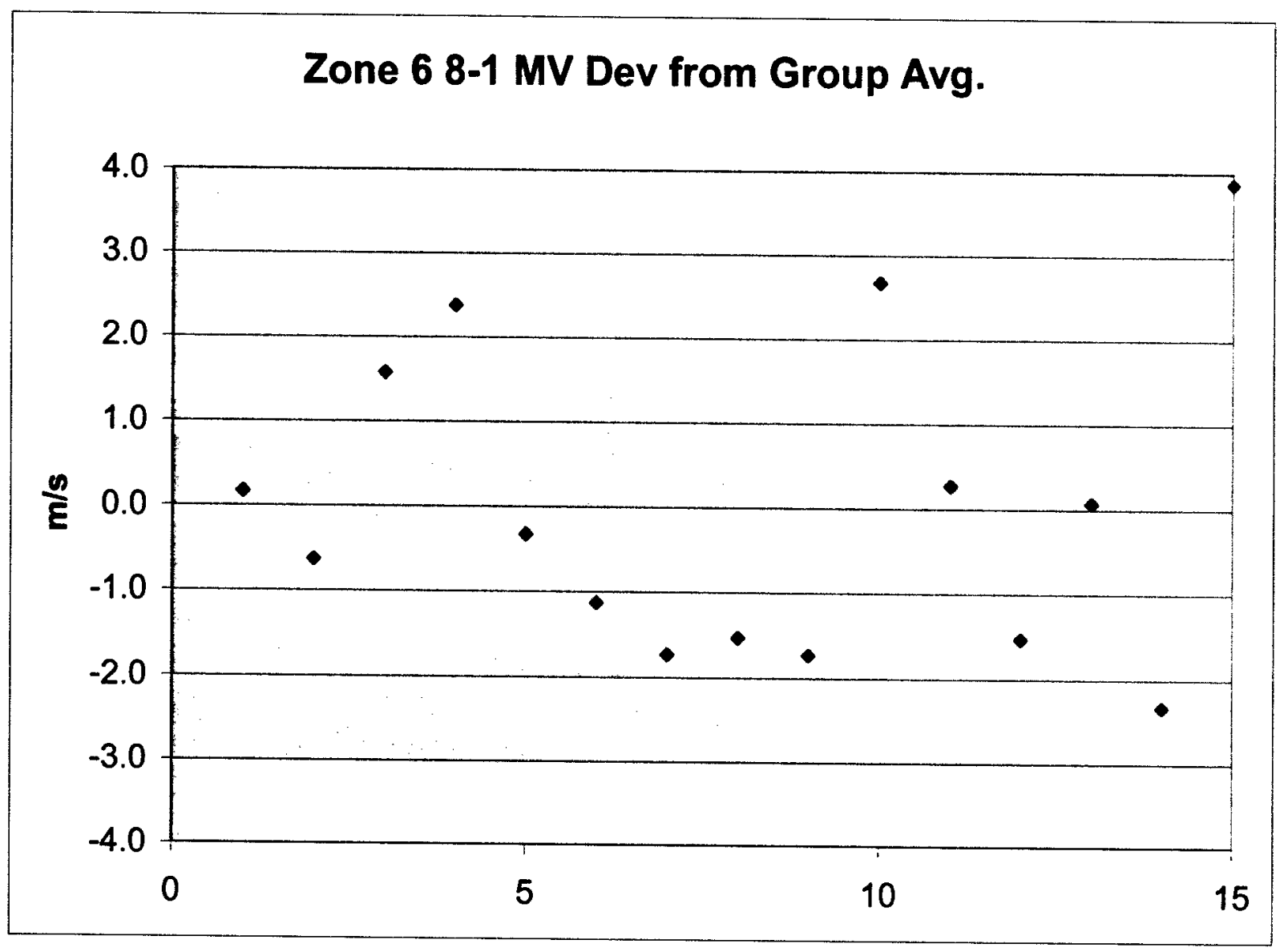




\begin{tabular}{|c|c|c|}
\hline $\begin{array}{c}\text { Zone 6 } \\
\text { Mission } \\
\text { tD }\end{array}$ & $\begin{array}{l}\text { Sampled } \\
\text { Increments } \\
\text { Temp @ }\end{array}$ & $\begin{array}{c}\text { Velocity } \\
\text { Measured - } \\
\text { Average } \\
\text { Velocity of } \\
\text { Group }\end{array}$ \\
\hline $9-2$ & 28.8 & 0.4 \\
\hline & 29.2 & -1.0 \\
\hline & 28.7 & -1.7 \\
\hline & 29.7 & -1.0 \\
\hline & 29.3 & 1.0 \\
\hline & 29.7 & -0.7 \\
\hline & 29.2 & -1.0 \\
\hline & 29.4 & -0.2 \\
\hline & 29.1 & -1.3 \\
\hline & 28.8 & -0.7 \\
\hline & & 1.1 \\
\hline & & 0.3 \\
\hline & & 2.8 \\
\hline & & 1.9 \\
\hline & & -0.1 \\
\hline
\end{tabular}

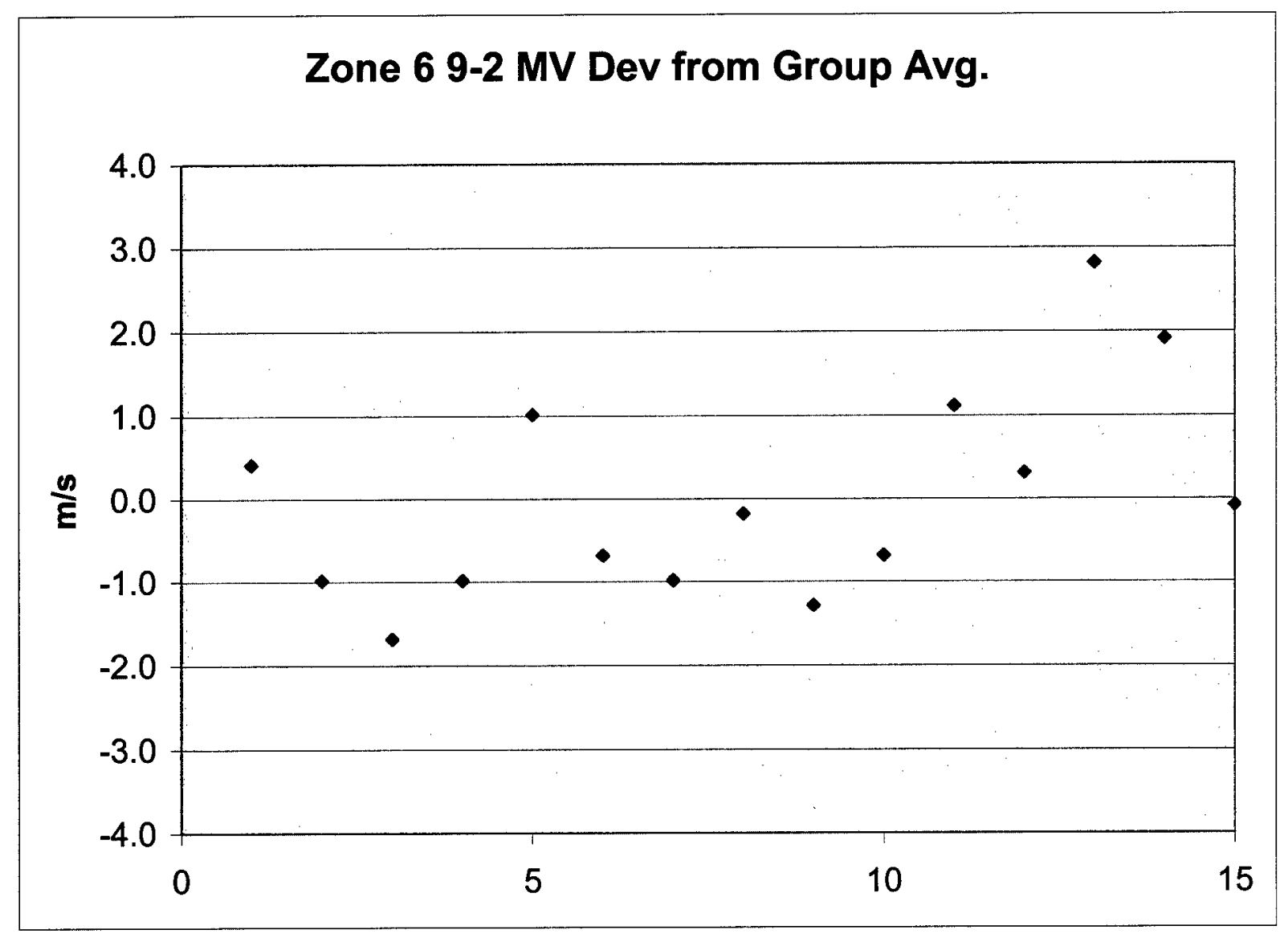




\begin{tabular}{|c|c|c|}
\hline Zones & $\begin{array}{c}\text { Velociky } \\
\text { Singion } \\
\text { Dencremonts } \\
\text { Tempe }\end{array}$ & $\begin{array}{c}\text { Measured - } \\
\text { Average } \\
\text { Veloclty of } \\
\text { Group }\end{array}$ \\
\hline $9-3$ & 33.1 & 2.5 \\
\hline & 32.3 & 0.0 \\
\hline & 31.6 & 1.9 \\
\hline & 31.4 & -0.2 \\
\hline & 31.4 & -1.1 \\
\hline & 31.7 & 2.1 \\
\hline & 31.2 & 0.4 \\
\hline & 31.2 & 0.4 \\
\hline & 32.8 & 0.3 \\
\hline & 31.8 & -1.9 \\
\hline & & 0.3 \\
\hline & & -1.2 \\
\hline & & -1.3 \\
\hline & & -2.2 \\
\hline & & -0.7 \\
\hline
\end{tabular}

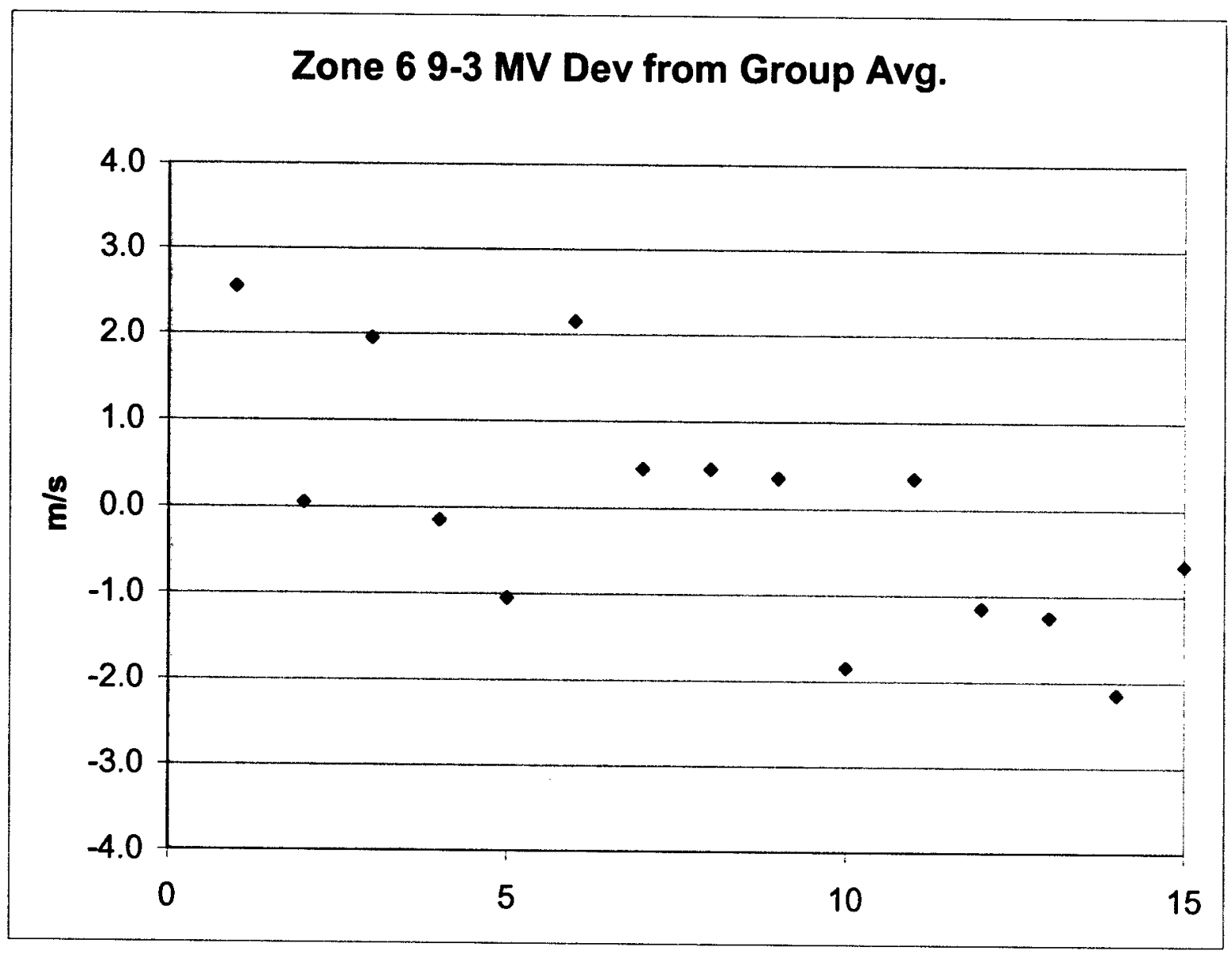




\begin{tabular}{|c|c|c|}
\hline $\begin{array}{c}\text { Zone 6 } \\
\text { Mission } \\
\text { ID }\end{array}$ & $\begin{array}{l}\text { Sampled } \\
\text { Increments } \\
\text { Temp @ }\end{array}$ & $\begin{array}{c}\text { Velocity } \\
\text { Measured - } \\
\text { Average } \\
\text { Velocity of } \\
\text { Group }\end{array}$ \\
\hline $10-1$ & 26.8 & -2.3 \\
\hline & 26.3 & -0.2 \\
\hline & 27.4 & 0.4 \\
\hline & 26.9 & -2.0 \\
\hline & 27.7 & -0.6 \\
\hline & 27.7 & 0.3 \\
\hline & 26.8 & 1.1 \\
\hline & 27.2 & -0.4 \\
\hline & 28.6 & 0.3 \\
\hline & 27.3 & -0.5 \\
\hline & & -0.1 \\
\hline & & 1.0 \\
\hline & & 2.5 \\
\hline & & 0.0 \\
\hline & & 1.2 \\
\hline
\end{tabular}

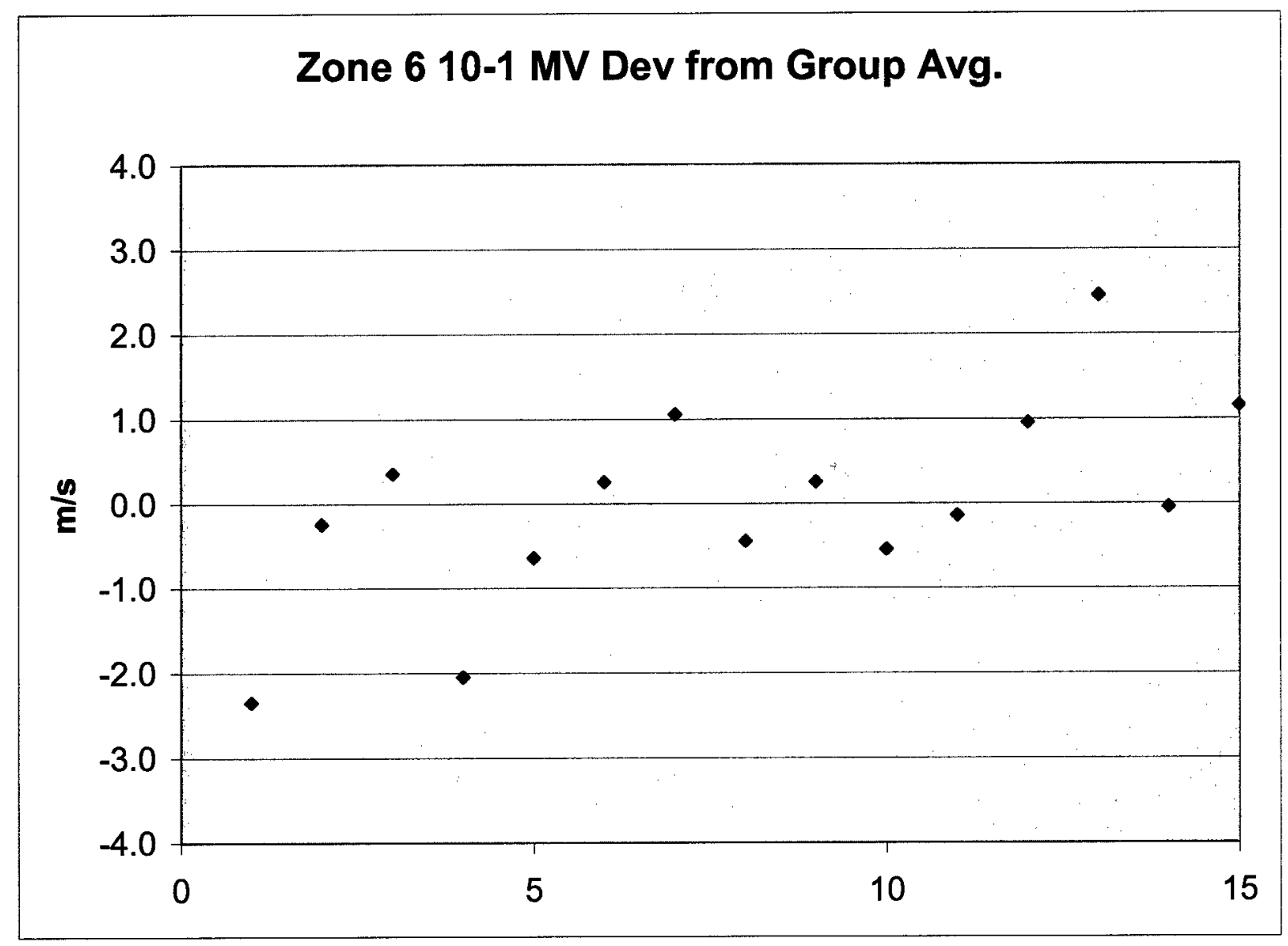




\begin{tabular}{|c|c|c|}
\hline $\begin{array}{l}\text { zome } \\
\text { malon }\end{array}$ & $\begin{array}{l}\text { Sumpled } \\
\text { merements } \\
\text { Tconpe }\end{array}$ & $\begin{array}{l}\text { Velocity } \\
\text { Measured - } \\
\text { Average } \\
\text { Velocty of } \\
\text { Group }\end{array}$ \\
\hline \multirow[t]{15}{*}{$10-2$} & 29.4 & -0.7 \\
\hline & 28.4 & 0.8 \\
\hline & 29.3 & 1.1 \\
\hline & 28.6 & 1.8 \\
\hline & 28.6 & 0.8 \\
\hline & 29.3 & -0.7 \\
\hline & 28.6 & -1.5 \\
\hline & 28.8 & -1.0 \\
\hline & 29.8 & 0.4 \\
\hline & 28.2 & -0.5 \\
\hline & & -0.4 \\
\hline & & -0.7 \\
\hline & & 1.7 \\
\hline & & -0.1 \\
\hline & & -1.2 \\
\hline
\end{tabular}

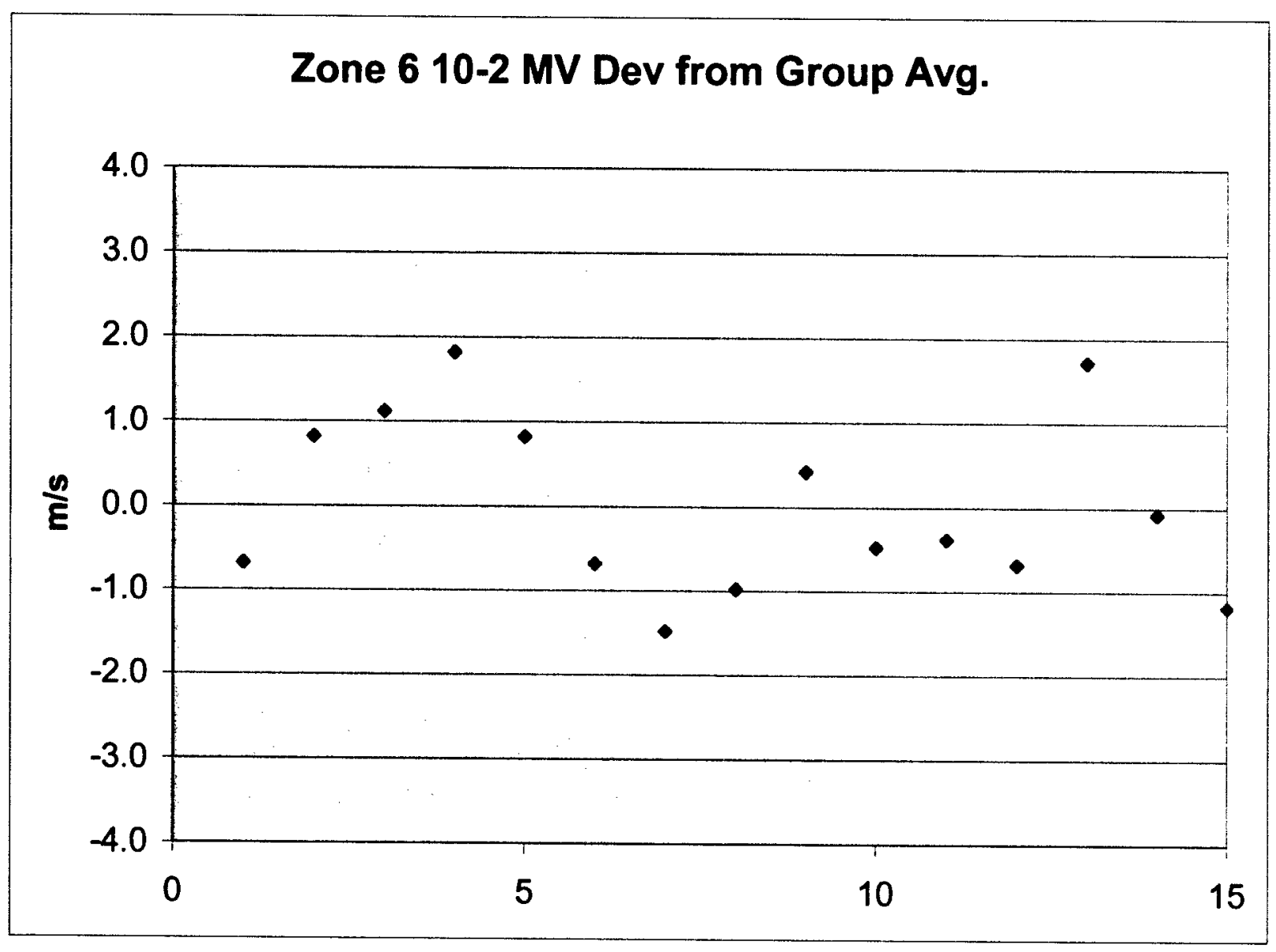




\begin{tabular}{|c|c|c|}
\hline $\begin{array}{c}\text { Zone 6 } \\
\text { Mission } \\
\text { ID }\end{array}$ & $\begin{array}{c}\text { Sampled } \\
\text { Increments } \\
\text { Temp C) }\end{array}$ & $\begin{array}{c}\text { Velocity } \\
\text { Measured - } \\
\text { Average } \\
\text { Velocity of } \\
\text { Group }\end{array}$ \\
\hline $10-3$ & 33.9 & 0.7 \\
\hline & 31.6 & 0.7 \\
\hline & 32.9 & -0.2 \\
\hline & 30.6 & 1.1 \\
\hline & 30.3 & 0.2 \\
\hline & 30.1 & -0.8 \\
\hline & 29.7 & 1.2 \\
\hline & 28.8 & 0.8 \\
\hline & 31.1 & -0.7 \\
\hline & 28.8 & -0.6 \\
\hline & & -0.3 \\
\hline & & -0.5 \\
\hline & & -0.3 \\
\hline & & -1.7 \\
\hline & & 0.2 \\
\hline
\end{tabular}

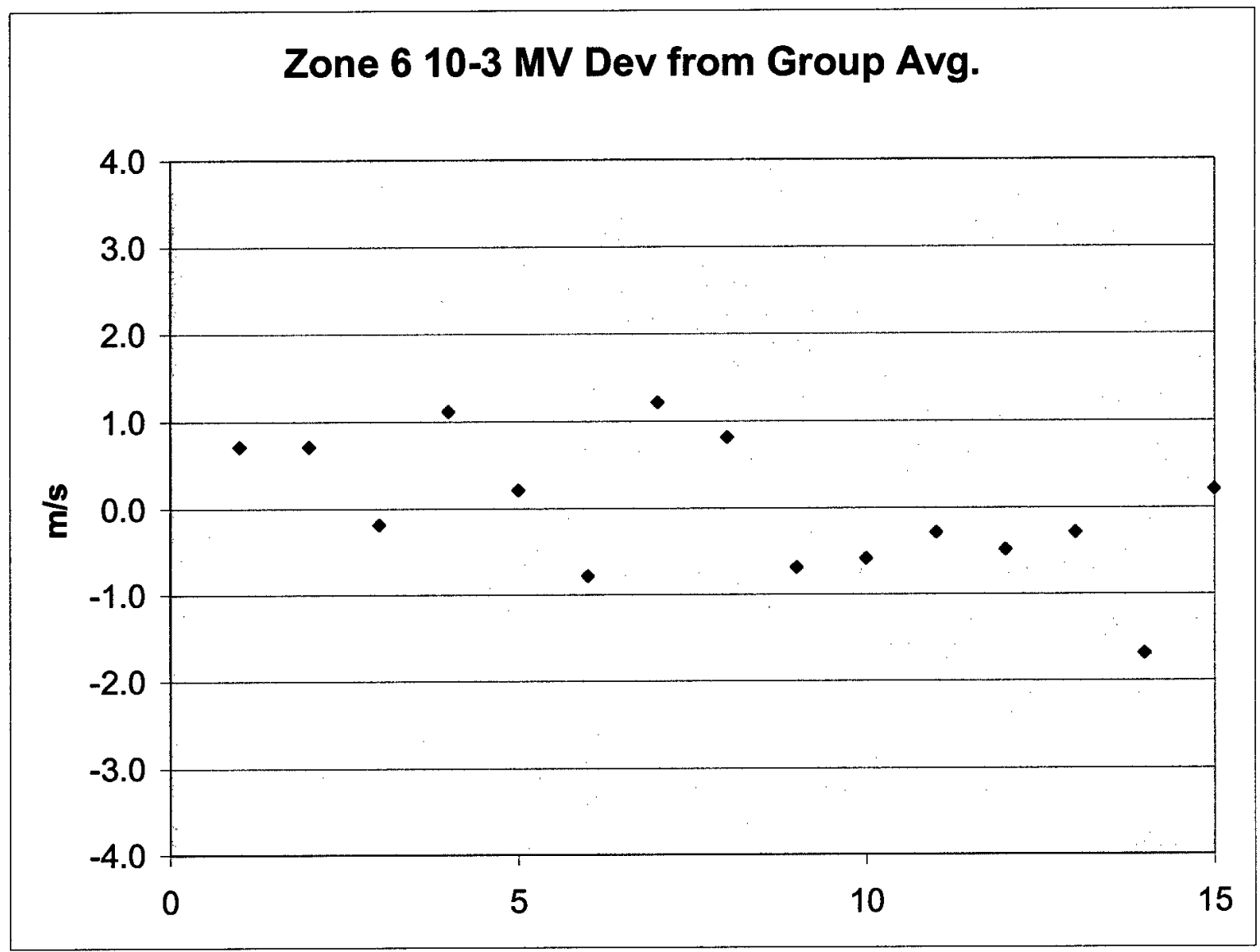




\begin{tabular}{|c|c|c|}
\hline Zome * & $\begin{array}{c}\text { Velocity } \\
\text { Senpled } \\
\text { Measured - } \\
\text { Average } \\
\text { Velocity of } \\
\text { Group }\end{array}$ \\
\hline $10-4$ & 37.3 & 0.4 \\
\hline & 35.4 & 0.4 \\
\hline & 37.9 & 1.4 \\
\hline & 35.5 & -1.2 \\
\hline & 31.7 & -1.3 \\
\hline & 30.9 & -0.3 \\
\hline & 32.3 & 1.2 \\
\hline & 36.3 & 0.2 \\
\hline & 34.9 & -1.7 \\
\hline & 32.8 & -1.1 \\
\hline & & 1.2 \\
\hline & & 0.7 \\
\hline & & 0.7 \\
\hline & & -0.4 \\
\hline & & -0.6 \\
\hline
\end{tabular}

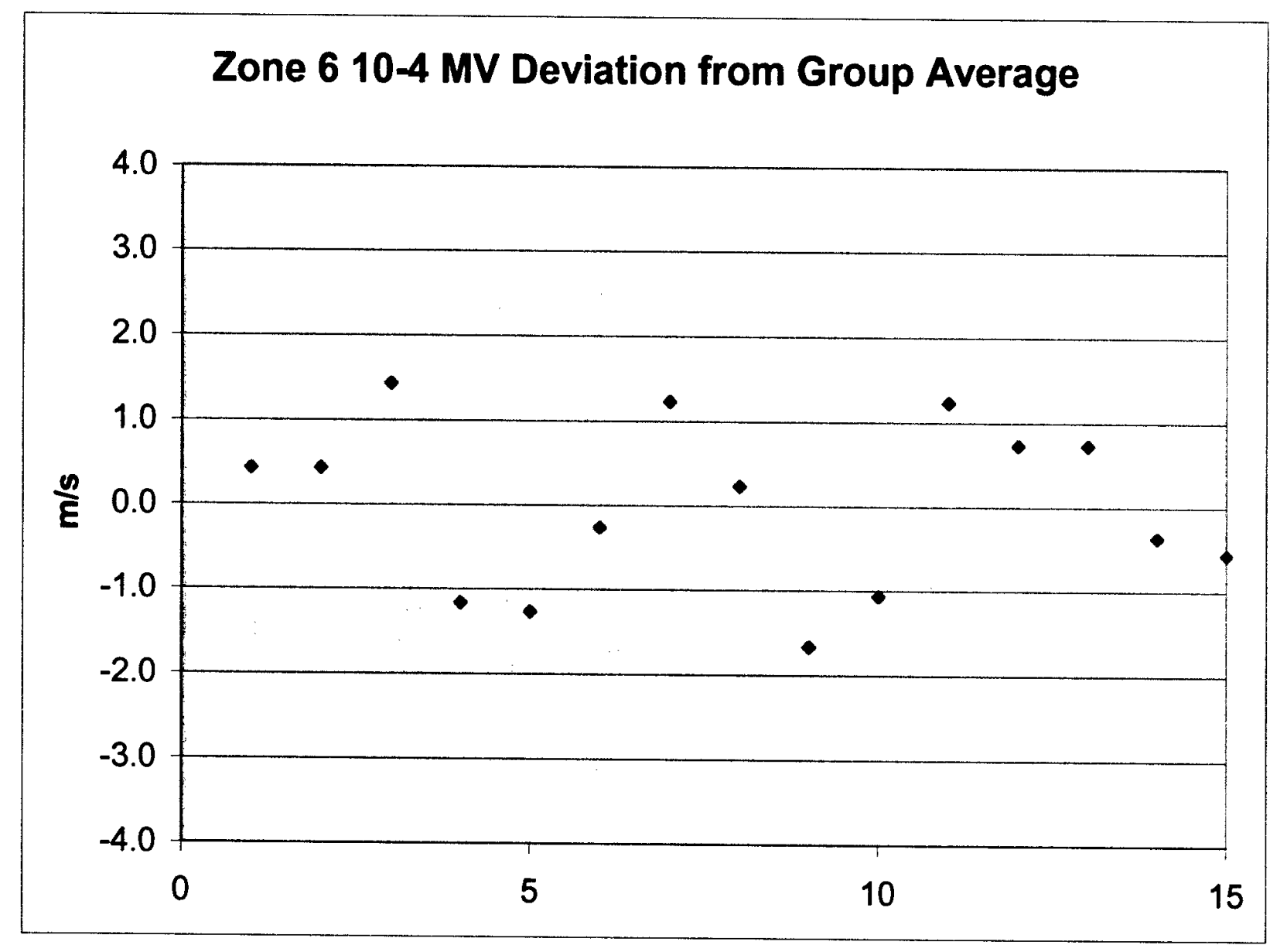




\section{DISTRIBUTION LIST}

Commander

U.S. Army Research, Development and Engineering Command

Armament Research, Development and Engineering Center

ATTN: AMSRD-AAR-EMK (2)

AMSRD-AAR-GC

AMSRD-AAR-QEM-A

AMSRD-AAR-AEE-W

AMSRD-AAR-AEW-S

Picatinny, NJ 07806-5000

Defense Technical Information Center (DTIC)

ATTN: Accessions Division

8725 John J. Kingman Road, Ste 0944

Fort Belvoir, VA 22060-6218

Director

U.S. Army Materiel Systems Analysis Activity

ATTN: AMXSY-EI

392 Hopkins Road

Aberdeen Proving Ground, MD 21005-5071

Commander

Soldier and Biological/Chemical Command

ATTN: AMSSB-Cll, Library

Aberdeen Proving Ground, MD 21010-5423

Director

U.S. Army Research Laboratory

ATTN: AMSRL-Cl-LP, Technical Library

Bldg. 4600

Aberdeen Proving Ground, MD 21005-5066

Chief

Benet Weapons Laboratory, CCAC

U.S. Army Research, Development and Engineering Command

Armament Research, Development and Engineering Center

ATTN: AMSRD-ARR-AEW (B)

Watervliet, NY 12189-5000

Director

U.S. Army TRADOC Analysis Center-WSMR

ATTN: ATRC-WSS-R

White Sands Missile Range, NM 88002 
Commander

Naval Air Warfare Center Weapons Division

1 Administration Circle

ATTN: Code 473C1D (2)

China Lake, CA 93555-6001

Chemical Propulsion Information Agency

ATTN: Accessions

10630 Little Patuxent Parkway, Suite 202

Columbia, MD 21044-3204

GIDEP Operations Center

P.O. Box 8000

Corona, CA $91718-8000$

PEO-GCS

ATTN: SFAE-GCS-CR

Picatinny, New Jersey 07806-5000

Commander

U.S. Army Yuma Proving Ground

Munitions and Weapons Division

ATTN: STEYP-MT-EW

Yuma, AZ 85365-9110 